\title{
FATORES NÃO-NUTRICIONAIS QUE AFETAM AS CONCENTRAÇÕES DE NITROGÊNIO URÉICO NO LEITE
}

\author{
Paula Marques Meyer
}

Tese apresentada à Escola Superior de Agricultura

"Luiz de Queiroz", Universidade de São Paulo, para obtenção do título de Doutor em Agronomia, Área de Concentração: Ciência Animal e Pastagens.

P I R A C I C A B A

Estado de São Paulo - Brasil

Outubro - 2003 


\section{FATORES NÃO-NUTRICIONAIS QUE AFETAM AS CONCENTRAÇÕES DE NITROGÊNIO URÉICO NO LEITE}

\section{Paula Marques Meyer}

Engenheiro Agrônomo

Orientador: Prof. Dr. PAULO FERNANDO MACHADO

Tese apresentada à Escola Superior de Agricultura

"Luiz de Queiroz", Universidade de São Paulo, para obtenção do título de Doutor em Agronomia, Área de Concentração: Ciência Animal e Pastagens.

P I R A C I C A B A

Estado de São Paulo - Brasil

Outubro - 2003 
Dados Internacionais de Catalogação na Publicação (CIP) DIVISÃO DE BIBLIOTECA E DOCUMENTAÇÃO - ESALQ/USP

\author{
Meyer, Paula Marques \\ Fatores não-nutric iona is que a fetam as concentra ções de nitrogênio \\ uréico no \\ leite / Paula Marques Meyer. - - Piracicaba, 2003. \\ $131 \mathrm{p}$. \\ Tese (doutorado) - Escola Supenior de Agric ultura Luiz de Queiroz, 2003. \\ Bibliografia. \\ 1. Dieta animal 2. Lactação animal 3. Leite 4. Nitrogênio 5. Nutrição 6. \\ Vacas leiteiras I. Título
}

CDD 636.2085 


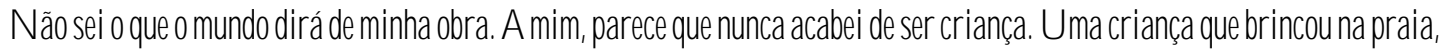

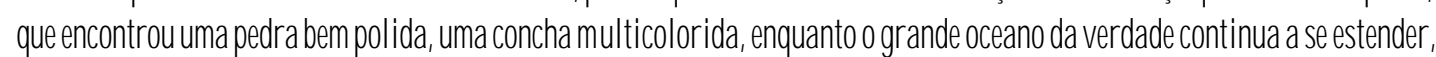
ainchirepdoabdatectsnesdhos

I sercinetan(16B I2) 
"Ainda que eu falasse as línguas dos homens e dos anjos, enão tivesse andr, seria comb o med quesca ou comb osino quetine Ainda queeu tivesseo domde profeia, econhecessetodbs os mistéios etoda a diênda; eainda queeu tivessetoda a fé demaneira tal quetransportasseos montes, enão tivesseamor, nada seria $E$ ainda que distribuísse toda a minha fatuna para o sustento dos pobres, e ainda que entregasse o meu conpo para ser queimado, e não tivesse amar, nada disso me aprovitaria O amor épadiente, éberigna $O$ amor não invẹa, não sevangloria, não se ensoberbece Não seporta inconvenientemente, não busca seus próprios interesses, não seimita, não suspeita mal. O amor não seal egra coma injustiça, mas se regozija coma verdade Tudb sofre, tudo crê, tudb espera, tudo suparta".

$16013,1-7$

Escritopor Paulo, por vdta dos anos 56.

"Se eu aprender ingês, francês, espanhd, alemão, dinês e dezenas de autros idionas, mas não sauber me comnicar como pessoa, de nada valemtodas as minhas palavras. Seeu conduir umaurso superior, andar deand no dedb efreqüentar arsos de especialização, mas viver distantedos prodlemas do pova, minha aultura não passa deuma inútil eudiçãa. Seeu morar no Nordeste, mas desconhecer os sofrimentos deminha regão efugir para as féias no Sul, eđténa América ou na Europa, enada fizer pda pronocão do homem não sau cistão. Seeu possuir a methor casa deminha nua, a roupa avançada do momento, o sapato da moda e não me lentbrar que sau responsáve por aqudes que moramna minha idade, andamde péno chão esecobrem desujo edemdambo, sau apenas ummanequimed crida. Seeu passar o fimdesemana emfestas, botes, farras eprogrames, semver a fore, o desemprego, oanalfabetistro ea doença, semesautar o gito abafado do povo quesearrasta àmargemda históiia, não sivoparanada".

Atualizado por DomHedder Câmara, arcedispo enéito deOlinda eReeife 


\section{DEDICATÓRIA}

\section{Ao mau pai,}

quemeensinou a amar ascisas da tera...

Por aguardar, ansioso, no portão, a minha chegada (atéhije..)!

Por ter sempreumsoriso nos lábios a cada vez querevế

Pelobrilhoemseus dhosquandoserefereaossasfilhos..

Por seorgulhar emdizer queérneu pai...

Mas, nofundo, sou eu quemseorgulha deapresentálocorro "reu pai"...

\section{À minha mãa \\ quemeensinoua amar as caisas dos livros (oestudo)... \\ Por velar meus passos.. ládo céu... \\ Faço o imposśved para não desapontála como estudante, como pesquisadora, enfim compessoa.}

\section{Aos mass imrias,}

Por me ensinarem cada uma seu modo, que nunca se perde par ser educadb, sincero, honestoe, sdbretudo, humilde

\section{Aomeu Paulo,}

meu grandecompanheiro detodas as horas..

Por fazer planos comigo ealimentar meus pequenos sonhos, que, aos poucos, estão se tomando realidadel Enfim.. por fazer partedeminha vida emrrar emmeu coração!

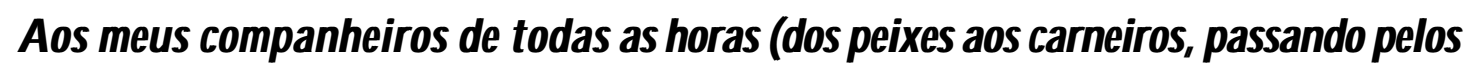 jabotis e gatos)... \\ Por seremmeus.. eisso basta!}




\section{AGRADECIMENTOS}

À Universidade de São Paulo e à Escola Superior de Agricultura "Luiz de Queiroz" por me acolherem desde 1991. A graduação, o mestrado e o doutorado são os bens mais valiosos que carrego comigo.

Ao orientador e Professor Doutor Paulo Fernando Machado, pela paciência e ensinamentos transmitidos e por me dar um grande voto de confiança ao aceitar ser meu orientador no doutoramento.

Ao amigo e Professor Doutor Alexandre Vaz Pires, pela amizade e confiança e por acreditar em minha capacidade de trabalho, contando com minha ajuda até hoje.

Ao Professor Doutor Wilson Roberto Soares Mattos, pela amizade e boa vontade em esclarecer minhas dúvidas e pelo sorriso sempre presente no rosto.

À Professora Doutora Ivanete Susin, pelo carinho, amizade, dedicação e preocupação com os alunos.

Ao Professor Doutor Sila Carneiro da Silva, pela disposição e prontidão em me ajudar todas as vezes de que necessitei.

Ao Professor Doutor Paulo Henrique Mazza Rodrigues, pelo empenho inestimável em corrigir este trabalho, sugerindo, criticando construtivamente e apoiando em todos os sentidos, com muito carinho e paciência. Por não medir esforços em ajudar quem quer que seja, especialmente a mim. Pela competência, profissionalismo e honestidade com que encara a ciência. 
À amiga Adriana Regina Bagaldo, pela amizade, cumplicidade e confiança, pelas horas ao telefone e pelas gargalhadas durante o mestrado e doutorado.

Ao amigo Paulo Garcez de Oliveira, pela confiança em mim depositada e por ser o dono de um grande coração, ajudando-me nos momentos em que mais precisei.

Ao grande amigo Arlei Coldebella, uma das melhores pessoas que já conheci..., por toda competência, humildade e honestidade; pelo auxílio nas análises estatísticas, às vezes noites a dentro; enfim, por não saber dizer "não". À sua esposa Áuria, pela amizade, carinho e confiança com que sempre me acolheu.

Aos colegas de doutorado Karyne Oliveira Coelho e Carlos Humberto Corassin, pelos bons momentos compartilhados, pela cumplicidade, parceria e apoio incondicional.

À Clínica do Leite, por me acolher durante o doutorado e fornecer condições para o desenvolvimento de experimentos e análises de leite. Aos grandes amigos Andrea, Camila, Cristiane, Dionete, Fabiana, Giany e João, pelas risadas e por toda ajuda, carinho e companheirismo durante esses anos.

À amiga e secretária Cleide Ely Martins do Departamento de Zootecnia, pela alegria e boa vontade comigo em todos os momentos.

Ao colega Francisco Carlos de Carvalho, pela inestimável paciência e boa vontade na revisão gramatical deste trabalho e por ser uma das pessoas mais competentes, criteriosas e perseverantes que conheço.

Aos colegas do IBGE José Antônio, Márcia, Mitsuo e Rosana, pela cumplicidade e pelas gargalhadas do dia-a-dia, pelo bom humor sempre presente e por compreenderem meu estresse e angústia de final de doutorado.

Ao parceiro Bob Dylan, por me fazer companhia e me manter acordada durante as noites de trabalho.

À Fazenda Colorado, por permitir a coleta de dados, sem os quais não seria possível a execução deste trabalho.

Ao CNPq, pela concessão da bolsa de pós-graduação. 


\section{SUMÁRIO}

Página

LISTA DE ABREVIATURAS...................................................................... xii

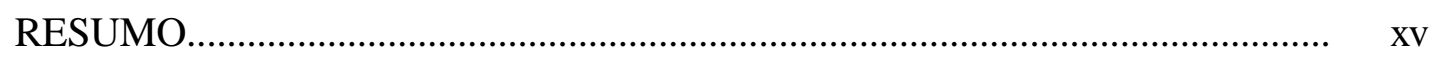

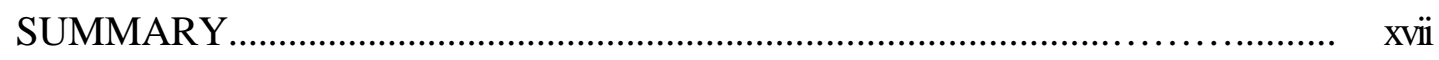

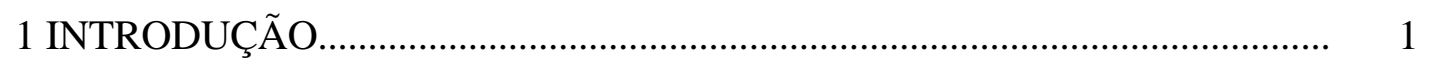

2 REVISÃO DE LITERATURA................................................................. 3

2.1 Nitrogênio uréico no leite............................................................................. 3

2.1.1 Origem do nitrogênio uréico plasmático......................................................... 3

2.1.2 Origem do nitrogênio uréico no leite............................................................ 5

2.1.3 Respostas à inadequação da nutrição protéica.............................................. 6

a) Desempenho produtivo................................................................................. 6

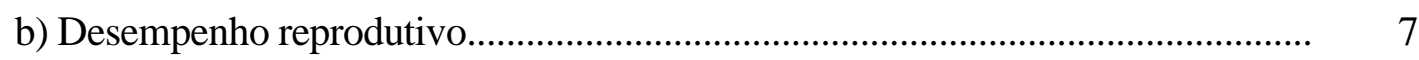

c) Poluição ambiental......................................................................................

2.1.4 Fatores que afetam as concentrações de nitrogênio uréico no sangue e no

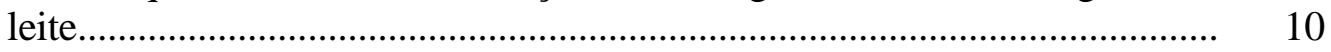

a) Consumo de proteína................................................................................. 10

b) Degradabilidade ruminal da proteína na dieta............................................................ 11

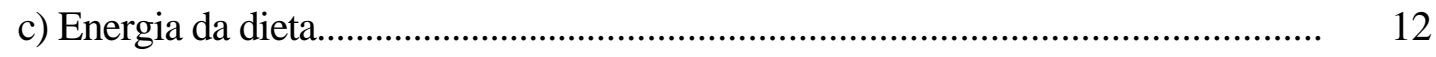

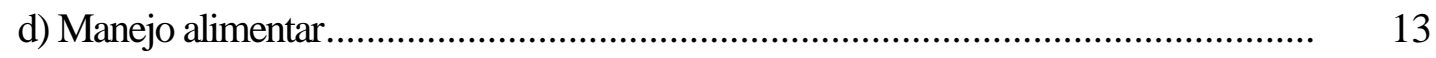

e) Sistema de produção......................................................................................... 14

f) Estação do ano............................................................................................. 15

g) Momento de amostragem............................................................................. 16

h) Diferença entre rebanhos....................................................................... 16 


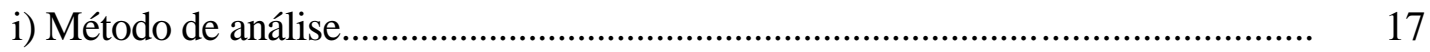

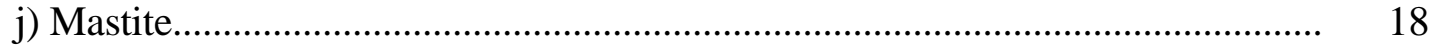

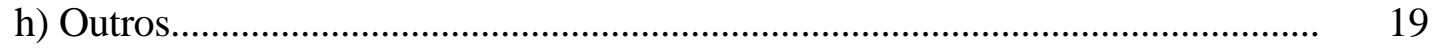

2.1.5 Padrões de referência e tamanho da amostra..................................................... 21

2.1.6 Análise de leite do tanque de expansão............................................................. 22

2.2 Outros fatores que afetam a composição do leite................................................. 23

2.2.1 Tempo de armazenamento........................................................................ 24

2.2.2 Método de armazenamento............................................................................... 25

2.3 Estudo da curva de lactação................................................................................ 27

2.4 Avaliação de modelos matemáticos................................................................. $\quad 30$

2.4.1 Hipótese ............................................................................................... 31

2.4.2 Análise de Sensibilidade................................................................... 32

2.4.3 Modelos para estimar as concentrações de nitrogênio uréico no leite.............. 33

3 MÉTODOS E TEMPO DE ARMAZENAMENTO DAS AMOSTRAS DE LEITE SOBRE NITROGÊNIO URÉICO, CONTAGEM DE CÉLULAS SOMÁTICAS E CONCENTRAÇÕES DE GORDURA, PROTEÍNA, LACTOSE E SÓLIDOS TOTAIS.................................................................. 36

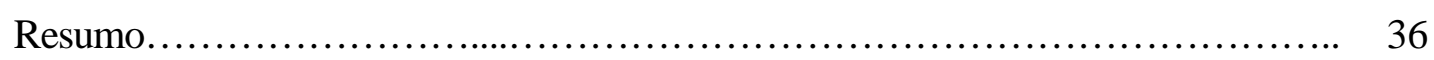

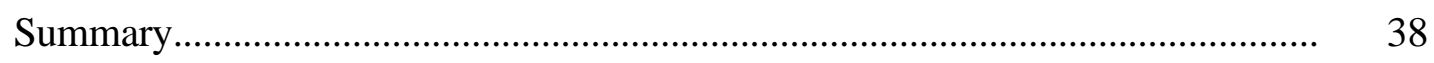

3.1 Introdução.............................................................................................. 39

3.2 Material e Métodos................................................................................... 40

3.2.1 Coleta de dados....................................................................................... 40

3.2.2 Análise estatística..................................................................................... 42

3.3 Resultados e Discussão...................................................................................... 43

3.3.1 Gordura do leite......................................................................................... 45

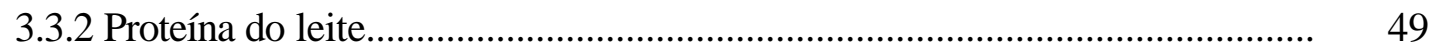

3.3.3 Lactose .................................................................................................. 50

3.3.4 Sólidos totais do leite.................................................................................. 51

3.3.5 Contagem de células somáticas................................................................... 53

3.3.6 Nitrogênio uréico no leite.............................................................................. 55 


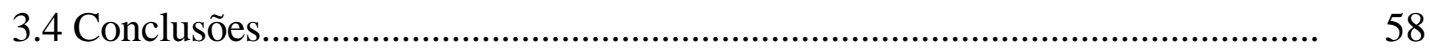

4 ESTUDO DOS FATORES NÃO-NUTRICIONAIS QUE AFETAM AS CONCENTRAÇÕES DE NITROGÊNIO URÉICO NO LEITE......................... 59

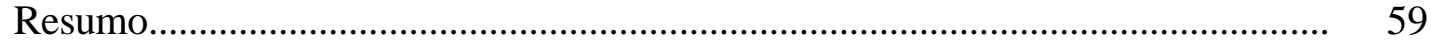

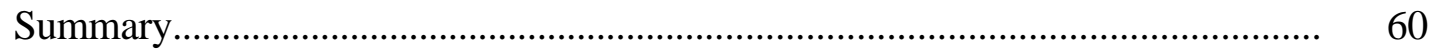

4.1 Introdução....................................................................................................... 61

4.2 Material e Métodos.......................................................................................... 62

4.2.1 Coleta de dados......................................................................................... 62

4.2.2 Análise estatística......................................................................................... 64

4.3 Resultados e Discussão................................................................................... 65

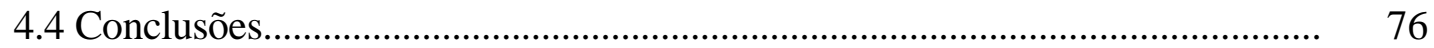

5 MODELOS PARA ESTIMAR AS CONCENTRAÇÕES DE NITROGÊNIO URÉICO NO LEITE, EM FUNÇÃO DOS DIAS EM LACTAÇÃO, NÚMERO DE LACTAÇÕES E ÉPOCA DE PARIÇÃO DE VACAS HOLANDESAS ............................................................................... 77

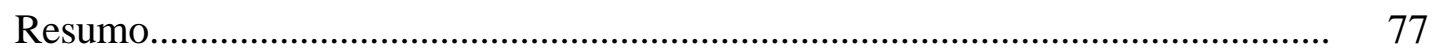

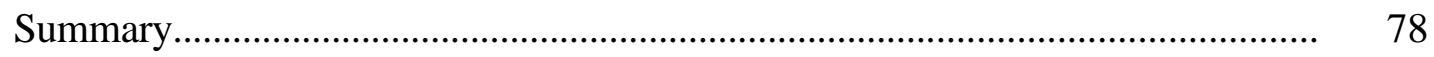

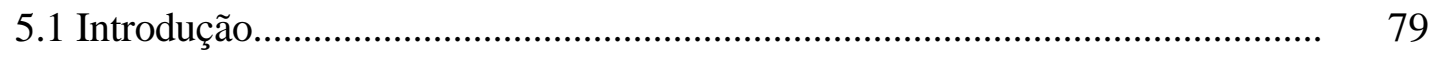

5.2 Material e Métodos......................................................................................... 80

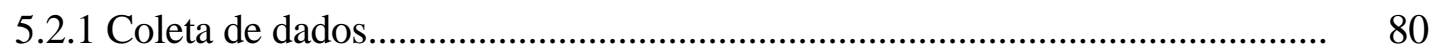

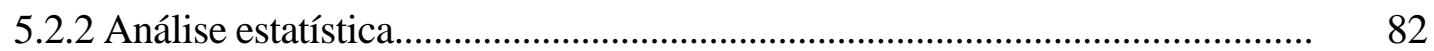

5.3 Resultados e Discussão............................................................................... 82

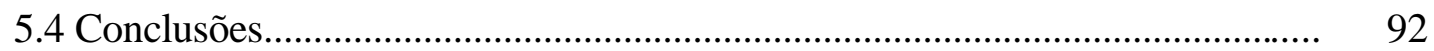

6 VALIDAÇÃO DE MODELOS DE PREDIÇÃO DAS CONCENTRAÇÕES DE NITROGÊNIO URÉICO NO LEITE DE VACAS LEITEIRAS........................................................................................ 93

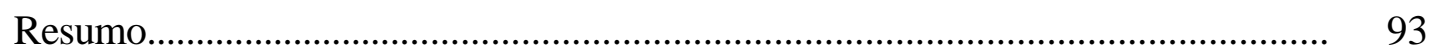

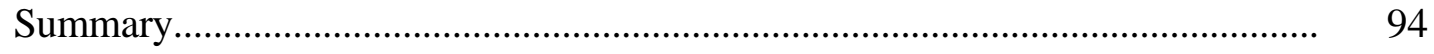

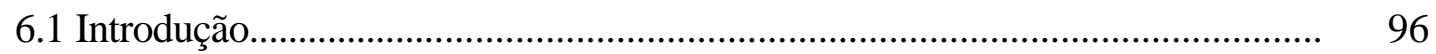

6.2 Material e Métodos....................................................................................... 97

6.2.1 Coleta de dados.......................................................................................... 9 


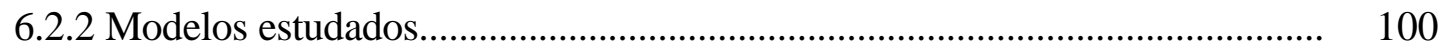

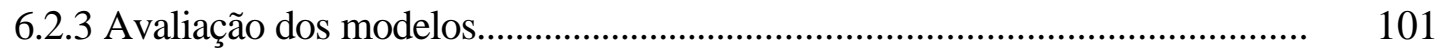

6.2.4 Análise estatística.............................................................................................. 103

6.3 Resultados e Discussão................................................................................... 104

6.3.1 Validação dos modelos usando o consumo individual de matéria seca estimado pelo NRC (2001)...................................................................... 104

6.3.2 Validação dos modelos usando o consumo real médio mensal do rebanho para estimar o consumo de matéria seca individual........................................ 110

6.3.3 Validação dos modelos usando o consumo real médio mensal de matéria seca do rebanho........................................................................................ 114

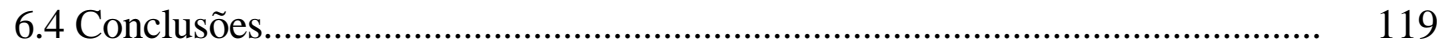

7 CONCLUSÕES GERAIS........................................................................ 120

REFERÊNCIAS BIBLIOGRÁFICAS.......................................................... 121 


\section{LISTA DE ABREVIATURAS}

$\mathrm{C}$

CCS

CMS

$\mathrm{CNF}$

DEL

$\mathrm{EE}$

EPM

FDA

FDN

Gord.

Gordkg.

IC 95\%

IN

Lact.

Lactkg.

LCCS

LCG4\%

Leite

LIC

LSC

MM

MS
- congelado

- contagem de células somáticas

-consumo de matéria seca

-carboidratos não-fibrosos

- dias em lactação

-extrato etéreo

-erro-padrão da média

-fibra em detergente ácido

-fibra em detergente neutro

- gordura do leite (\%)

-produção de gordura em kg/dia

-intervalo de confiança de $95 \%$

-ingestão de nitrogênio

-lactose $(\%)$

- produção de lactose em kg/dia

- logaritmo natural

- produção de leite corrigida para 4\% de gordura

- produção de leite

- limite inferior de confiança

- limite superior de confiança

-matéria mineral

-matéria seca 
$\mathrm{NH}_{3}$

$\mathrm{NH}_{4}{ }^{+}$

NL

Nleite

NU

NUL

$\mathrm{NUL}_{\text {novo }}$

NUL velho

NUP

NUS

PB

PDR

Peso

PL

PNDR

$\operatorname{Prob}(1)$

$\operatorname{Prob}(2)$

Prob.

Prot.

Protkg.

PV

$\mathrm{R}$

R vs. C

$[(\mathrm{R}+\mathrm{C}) v s .(\mathrm{TC}+\mathrm{TV})]$

Rel. g/p

RQMEP

SL

ST

STkg. -amônia

-íon amônio

-número de lactações

- secreção de nitrogênio no leite

-nitrogênio urinário

-nitrogênio uréico no leite

-nitrogênio uréico no leite após a correção

-nitrogênio uréico no leite antes da correção

-nitrogênio uréico no plasma

-nitrogênio uréico no sangue

- proteína bruta

-proteína degradável no rúmen

-peso corporal

-produção de leite

-proteína não-degradável no rúmen

-probabilidade estatística de o coeficiente angular da reta ("slope") diferir de zero

- probabilidade estatística da falta de ajuste da equação linear

-probabilidade estatística

-proteína do leite (\%)

- produção de proteína em kg/dia

-peso vivo

-refrigerado

-contraste resfriado $v s$. congelado

-contraste resfriado $v s$. não-resfriado

-relação gordura/proteína

-raiz quadrada média do erro de predição

- semana de lactação

-sólidos totais (\%)

-produção de sólidos totais em kg/dia 
TC

TC vs. TV

TV

$v s$.

- armazenado em temperatura controlada

- contraste temperatura controlada $v s$. temperatura variável -armazenado em temperatura variável

-versus 


\title{
FATORES NÃO-NUTRICIONAIS QUE AFETAM AS CONCENTRAÇÕES DE NITROGÊNIO URÉICO NO LEITE
}

\author{
Autora: PAULA MARQUES MEYER \\ Orientador: Prof. Dr. PAULO FERNANDO MACHADO
}

\section{RESUMO}

Essa tese compreende 4 estudos, com o objetivo de avaliar os fatores nãonutricionais que afetam as concentrações de nitrogênio uréico no leite (NUL) de vacas leiteiras de um rebanho comercial, desenvolvendo modelos para sua predição, assim como validando modelos de predição já existentes na literatura. $\mathrm{O}$ primeiro experimento foi conduzido para avaliar métodos e tempos de armazenamento das amostras nos resultados da análise do leite (concentração de gordura, proteína, lactose e sólidos totais (ST), contagem de células somáticas (CCS) e NUL). O leite foi coletado do tanque de expansão e colocado em 210 frascos. As amostras foram designadas a um arranjo fatorial de tratamentos $4 \mathrm{X} 5+1$. Os métodos de armazenamento foram: 1) refrigerado $(\mathrm{R})$; 2) congelado (C); 3) armazenado em temperatura controlada (TC) e 4) armazenado em temperatura variável (TV). O tempo de armazenamento das amostras foi: 3, 6, 9, 12 e 15 dias, mais dia 0 , como controle. Foram realizados análise de variância, análises de regressão até efeito quadrático e contrastes ortogonais. A CCS foi transformada em logaritmo natural (LCCS). A concentração de gordura sofreu diminuições lineares, em função do tempo, para TC e TV, assim como a de ST e o LCCS para todos métodos de armazenamento. O NUL apresentou falta de ajuste para as equações lineares e 
quadráticas para todos os métodos de armazenamento. Para os demais estudos, foram utilizadas 8.833 observações, provenientes de 855 vacas holandesas, de setembro/2000 a janeiro/2002. Dados zootécnicos foram coletados no dia da amostragem de leite, realizada mensalmente. As parições foram divididas em duas épocas: verão e inverno. $\mathrm{O}$ objetivo do segundo trabalho foi estudar a influência de fatores não-nutricionais sobre NUL. Foram realizadas análises de regressão linear simples, usando os dados coletados como variáveis independentes e NUL como variável dependente. A produção de leite e a concentração de proteína do leite foram os fatores que mais afetaram as concentrações de NUL. O terceiro estudo teve por objetivo desenvolver modelos para estimar NUL, em função dos dias em lactação, número de lactações e época de parição, em condições de campo. Para estimar NUL, foi utilizado o modelo proposto por Wood (1967) para descrever a curva de lactação. Os modelos foram ajustados por quadrados mínimos. As concentrações de NUL apresentaram comportamento semelhante à curva de lactação, em função dos dias em lactação, diferindo entre as $1^{\mathrm{a}}, 2^{\mathrm{a}}, 3^{\mathrm{a}}$ e $45^{\mathrm{a}}$ lactações, sendo influenciadas pela época de parição. A finalidade do quarto estudo foi validar três modelos de predição de NUL. O modelo 1 foi NUL = NU/12,54, o modelo 2 foi NUL = NU/17,6 e o modelo 3 foi NUL = NU/(0,0259 x PV), sendo NU = nitrogênio urinário e $\mathrm{PV}=$ peso vivo. Para avaliação dos modelos, foram medidas a acurácia, a precisão e a robustez. Considerando os três métodos de se estimar o consumo de matéria seca dos animais, é possível afirmar que os três modelos de predição de NUL diferem entre si quanto à acurácia, precisão e robustez, apresentando uso questionável no campo. 


\title{
NON-NUTRITIONAL FACTORS THAT AFFECT MILK UREA NITROGEN CONCENTRATIONS
}

\author{
Author: PAULA MARQUES MEYER \\ Adviser: Prof. Dr. PAULO FERNANDO MACHADO
}

\section{SUMMARY}

This thesis consists of 4 studies, with the objective to assess nonnutritional factors that may affect milk urea nitrogen concentration (MUN) of dairy cows from a commercial herd, developing models for their prediction, as well as, validating prediction models from the literature. The first trial was conducted to evaluate methods and time of storage on the results of milk analysis (concentration of fat, protein, lactose and total solids (TS), somatic cells count (SCC) and MUN). Milk was collected from a bulk tank, poured into 210 vials and preserved with bronopol. Samples were used in a completely randomized design with a $4 \mathrm{X} 5+1$ factorial arrangement of treatments. One factor was storage method: 1) refrigerated (R), 2) frozen (F), 3) stored at controlled temperature (CT) and 4) stored at variable temperature (VT). The other factor was storage time of samples: 3, 6, 9, 12 and 15 days after collection, plus day 0 , used as control. Analysis of variance, regression analysis up to quadratic effect and orthogonal contrasts were done. Somatic cells count was analyzed as natural log transformation (LSCC). Fat concentration showed significant linear decreases, in function of time, for CT and VT, as well as, total solids concentration and LSCC for all storage methods. Milk urea nitrogen showed lack of fit, through time, for all storage methods. For the 
other 3 studies, 8,833 observations were used, coming from 855 Holstein cows, from September/2000 up to January/2002. Data were collected on the milk sampling day, which was done monthly. Calving seasons (CS) were divided in summer and winter. The objective of the second study was to investigate further the influence of non-nutritional factors on MUN. Simple linear regression analyses were done, using all other collected data as independent variable and MUN as dependent variable. Milk production and milk protein concentration were the most associated factors with MUN concentrations. The objective of the third study was to develop models to estimate MUN, in function of days in milk (DIM), lactation number and calving season, for field conditions. To estimate MUN, a model, proposed by Wood (1967) to describe the lactation curve, was used. Models were adjusted by least square methodology. Concentrations of MUN showed similar pattern to the lactation curve, in function of DIM, differing among $1^{\text {st }}, 2^{\text {nd }}, 3^{\text {rd }}$ and $4^{\text {th }}-5^{\text {th }}$ lactations and being influenced by calving season. The objective of the fourth study was to validate three models for predicting MUN. Model 1 was MUN = UN/12.54, model 2 was MUN = UN/17.6 and model 3 was $\mathrm{MUN}=\mathrm{UN} /(0.0259 \times \mathrm{BW})$, where UN $=$ urinary nitrogen and $\mathrm{BW}=$ body weight. To evaluate those models, accuracy, precision and robustness were tested. Considering the three methods of estimating dry matter intake of animals, it's possible to conclude that the three models for predicting MUN differ among themselves, regarding accuracy, precision and robustness, presenting questionable use in the field. 


\section{INTRODUÇÃO}

Há muito se conhece a importância da proteína na dieta para o bom desempenho produtivo de vacas em lactação. Assim como a deficiência, o excesso de proteína na dieta também causa impacto sobre a atividade leiteira.

A concentração de nitrogênio uréico no leite (NUL) vem sendo proposta como um indicador para o monitoramento da nutrição protéica de vacas em lactação (Hof et al., 1997; Jonker et al., 1999; Kohn, 2000; Godden et al. 2001b; Jonker et al., 2002a), uma vez que apresenta boa correlação com a concentração de nitrogênio uréico no plasma (NUP) ou no sangue (NUS). Para a determinação de NUL, as amostras são coletadas de forma nãoinvasiva e direta, por meio da amostragem de leite durante as ordenhas, representando, assim, um indicador simples, rápido e barato de avaliação do "status" nutricional de vacas em lactação (Roseler et al., 1993; Butler et al., 1995). Esse indicador pode, então, ser usado como uma ferramenta auxiliar no ajuste da dieta de vacas em lactação.

Ademais, segundo avaliação recente, a utilização de NUL para ajustar o conteúdo de proteína e energia da ração pode, por meio da redução no custo de alimentação e aumento no desempenho, gerar benefícios da ordem de 10:1 (Nelson, 1995).

Contudo, para interpretar os dados de concentração de nitrogênio uréico no leite corretamente, é importante levar em consideração outros fatores não-nutricionais, além da dieta do animal: produção de leite (Oltner et al., 1985; Carlsson et al., 1995), idade da vaca (Carlsson et al., 1995), estágio da lactação (Carlsson et al., 1995) e peso vivo (Oltner et al., 1985; Jonker et al., 1998). A concentração de proteína (Jonker et al., 1999) e de gordura do leite (Jonker et al., 1998) também pode alterar a concentração de NUL, assim o como 
método de armazenamento e a idade das amostras (Eicher et al., 1999; Godden et al., 2000). Variações diurnas da concentração de NUL foram encontradas por alguns pesquisadores (Gustafsson \& Palmquist, 1993; Roseler et al., 1993; Carlsson \& Bergström, 1994;), assim como variações sazonais sobre NUL também foram relatadas por Carlsson \& Pehrson (1993).

A maioria dos estudos citados acima foi realizada em animais individuais, sob condições experimentais, usando testes químicos para mensurar NUL. Por conseguinte, a associação entre NUL e ambos, manejo nutricional e desempenho, deve ser determinada em condições de campo, usando procedimentos de testes comerciais (Sackett et al., 1991). Assim, para investigar tais associações, faz-se necessária uma avaliação dos fatores rãonutricionais que afetam NUL.

Portanto, o objetivo desta tese, desenvolvida na forma de quatro capítulos, foi estudar os fatores não-nutricionais que afetam as concentrações de NUL. No primeiro experimento, foram estudados métodos e tempos de armazenamento das amostras de leite sobre NUL e também sobre outros componentes do leite. O objetivo do segundo estudo foi avaliar os fatores não-nutricionais, relativos ao animal, sobre NUL. No terceiro, foram desenvolvidos modelos de predição de NUL, em função dos dias em lactação, número de lactações e época do parto. O quarto e último estudo objetivou validar modelos de predição de NUL, já existentes na literatura internacional, visando contribuir para avaliação da adequação nutricional de dietas de vacas leiteiras e predição da excreção de nitrogênio para o ambiente. 


\section{REVISÃO DE LITERATURA}

\subsection{Nitrogênio uréico no leite}

\subsubsection{Origem do nitrogênio uréico plasmático}

O nitrogênio uréico plasmático é oriundo do nitrogênio amoniacal absorvido pela parede ruminal e do nitrogênio amoniacal proveniente da deaminação de aminoácidos, sejam eles oriundos da absorção pelo trato digestivo ou oriundos da mobilização dos tecidos corporais e que não foram utilizados pelo animal (Dijkstra et al., 1998).

Das fontes listadas acima, Roseler et al. (1993) afirmaram que o nitrogênio oriundo da degradação protéica no rúmen é o principal contribuinte para a uréia plasmática. Quando a concentração de amônia no rúmen excede a capacidade de captura e utilização pela microbiota ruminal, a mesma é absorvida pela parede do rúmen e transportada ao fígado, por meio do sistema porta e, então, transformada em uréia. A difusão da amônia pelas membranas lipídicas celulares, tal como a parede ruminal, ocorre somente na forma não-ionizada $\left(\mathrm{NH}_{3}\right)$. Uma vez que o pKa da amônia é igual a 9,25 e o pH ruminal entre 6,0-6,8, a principal forma em que a amônia é encontrada no rúmen é como íon amônio $\left(\mathrm{NH}_{4}{ }^{\dagger}\right)$. Portanto, além das concentrações ruminais de amônia, sua absorção pela parede do rúmen também é influenciada pelo $\mathrm{pH}$ ruminal e por todos fatores que afetam esse parâmetro. A amônia, por ser tóxica ao animal, é rapidamente convertida em uréia no fígado.

O excesso de aminoácidos e peptídeos é deaminado no fígado e o nitrogênio, convertido em uréia (Swenson \& Reece, 1993). A uréia entra no sistema circulatório pelos 
sinusóides hepáticos, que drenam para a veia hepática e se torna parte de todo nitrogênio uréico do sangue. A uréia é filtrada do sangue pelos rins, sendo excretada pela urina. O sangue entra nos rins por meio da artéria renal e é filtrado pelos néfrons (Guyton, 1982). Esse processo concentra a uréia para excreção na urina. Por causa do fluxo contra-corrente e das diferenças na permeabilidade da membrana ao longo da porção ascendente e descendente das alças de Henle, um gradiente de concentração para difusão da uréia dentro da urina é criado para remover uréia do sangue (Swenson \& Reece, 1993).

O fluxo sangüíneo pelos rins é constante, assegurando uma taxa constante de filtração de uréia (mililitros de sangue filtrado por minuto), independente do volume de urina produzido. Com baixo volume de urina, a concentração de uréia poderia ser maior do que com grande volume, mas uma quantia similar de sangue poderia ser filtrada, removendo-se, assim, a uréia. Além disso, com concentrações altas de uréia no sangue, mais uréia poderia ser removida por minuto, mas a quantia total de sangue filtrado permaneceria similar. Portanto, a excreção de uréia é proporcional à sua concentração no sangue. Por fim, a uréia pode ser excretada pela urina ou reciclada para o rúmen (Swenson \& Reece, 1993).

Fatores que elevam as concentrações ruminais de amônia e o pH ruminal aumentam a transferência da amônia para o sangue. Schepers \& Meijer (1998) observaram associação elevada e positiva (coeficiente de correlação igual a 0,80 ) entre concentração de proteína degradável na dieta e concentração de nitrogênio uréico no leite (NUL). Embora mais correlacionadas com o teor de proteína degradável na dieta, as concentrações de nitrogênio uréico sangüíneo também são correlacionadas com o teor de proteína não-degradável na dieta (Roseler et al., 1993). Herrera-Saldana \& Huber (1989) demonstraram que vacas alimentadas com dietas contendo teores de proteína não-degradável acima das exigências apresentavam menores concentrações ruminais de amônia e maiores concentrações de nitrogênio plasmático. Tal fato é explicado pela maior deaminação dos aminoácidos absorvidos pelo trato digestivo, mas não-aproveitados pelo organismo.

Maiores concentrações plasmáticas de nitrogênio uréico também são esperadas em condições de intenso catabolismo protéico desencadeado por balanço 
energético negativo em início de lactação, deficiência protéica ou subnutrição (Roseler et al., 1993). Cerca de 11 a $15 \mathrm{~kg}$ de proteína corpórea podem ser mobilizados durante os primeiros 60 dias de lactação (NRC, 1989).

\subsubsection{Origem do nitrogênio uréico no leite}

A uréia é uma pequena molécula neutra que se difunde facilmente pelas membranas. Uma vez que o leite é secretado pelas células alveolares da glândula mamária, a uréia se difunde para dentro ou para fora das células secretoras, entrando em equilíbrio com a uréia plasmática (Jonker et al., 1998). O nitrogênio não-protéico representa entre 5\% e 6\% do total de nitrogênio do leite, enquanto que o nitrogênio protéico representa $95 \%$ desse total. O nitrogênio protéico do leite é formado por $80 \%$ de caseína e $20 \%$ de proteínas do soro. Por sua vez, o nitrogênio não-protéico é composto de 30-50\% de nitrogênio uréico, sendo o restante formado, principalmente, pela creatinina, ácido úrico, aminoácidos e amônia (Roseler et al., 1993; Broderick \& Clayton, 1997).

Segundo Roseler et al. (1993), as concentrações de NUL podem ser utilizadas para estimar as concentrações de nitrogênio uréico no sangue (NUS) ou no plasma (NUP), uma vez que o coeficiente de correlação entre NUP e NUL foi de 0,88. Jonker et al. (1998) concordam com essa afirmativa.

Ao estudar as concentrações de NUS e NUL ao longo do dia, Gustafsson \& Palmquist (1993) demonstraram que as concentrações de NUS sobem após a alimentação, atingindo pico 3 horas após seu início, voltando às concentrações iniciais, obtidas antes da refeição, em 5 a 6 horas. As concentrações de NUL apresentaram semelhante padrão de resposta ao longo do dia, apesar de atrasadas em uma hora em relação às de NUS.

\subsubsection{Respostas à inadequação da nutrição protéica}

\section{a) Desempenho produtivo}


Há muito se conhece a importância da proteína na dieta para o bom desempenho produtivo de vacas em lactação. Ao se aumentar o teor de proteína bruta da dieta, de $12 \%$ a $18 \%$, aumenta-se também a produção de leite, em virtude do maior consumo de matéria seca. Embora se reconheça que o aumento no consumo de matéria seca, observado ao se aumentar a proteína bruta da dieta de $8 \%$ para $15 \%$, ocorra em virtude do aumento da digestibilidade, aumentos no consumo de matéria seca, ao se elevar a proteína de $15 \%$ para $18 \%$, possuem causa desconhecida (Huber \& Kung, 1981).

Entretanto, Hogan (1975), Edwards et al. (1980) e Kung \& Huber (1983) demonstraram que aumentos crescentes de proteína na dieta produzem incrementos decrescentes de produção de leite, ou seja, a adição de uma unidade de proteína na dieta resulta em aumentos de produção de leite cada vez menores. Portanto, o aumento dos teores de proteína na dieta nem sempre é economicamente viável, em virtude do custo adicional da proteína excedente.

Assim como a deficiência, o excesso de proteína na dieta também causa impacto econômico sobre a atividade leiteira. Jonker \& Kohn (1998) determinaram que os teores de proteína, normalmente utilizados por propriedades leiteiras americanas, eram $8 \%$ a $16 \%$ maiores que os recomendados pelo NRC (1989). Nessas condições, é possível que 0,55 a 0,99 quilo de equivalente em farelo de soja esteja sendo utilizado em excesso. Ainda segundo esses autores, cada incremento $(\mathrm{mg} / \mathrm{dL})$ na concentração de NUL, de 16 para 20 $\mathrm{mg} / \mathrm{dL}$, representa um gasto adicional de US\$70,00/vaca/ano com a aquisição de suplementos protéicos.

Além disso, a utilização de NUL para ajustar o conteúdo de proteína e energia da ração pode, por meio da redução no custo de alimentação e aumento de desempenho, gerar benefícios da ordem de 10:1 (Nelson, 1995). De acordo com Ferguson (1997), o excesso de $20 \%$ de proteína na dieta, aumenta o custo aos produtores em US\$50,00/vaca/ano (ou seja, 100 vacas=US\$5.000,00/ano). No caso do teste de NUL, o custo é de US\$0,50/vaca/mês (ou seja, 100 vacas=US\$50,00/mês=US\$600,00/ano). 
Além do custo adicional com alimentação, a detoxificação da amônia pelos tecidos também é um processo energeticamente caro. A conversão de duas moléculas de amônia em uma molécula de uréia gasta 4 ATPs, de forma que a excreção de um grama de nitrogênio pela urina custa 5,45 Kcal de energia líquida para lactação (Blaxter, 1962) ou 13,3 Kcal de energia digestível (Broderick \& Clayton, 1997). Se o consumo de 100 gramas de proteína bruta que não é utilizada pelo organismo representa uma perda de 0,2 Mcal de energia líquida (Haresign \& Cole, 1988), então o consumo de 1.000 gramas de PB em excesso resultaria em uma perda de 2 Mcal de energia líquida por dia. Isso significa quase $30 \%$ da energia de mantença de uma vaca leiteira ou energia suficiente para produção de, aproximadamente, 3 quilos de leite.

\section{b) Desempenho reprodutivo}

O efeito de elevados consumos de proteína bruta sobre o desempenho reprodutivo de vacas em lactação é um assunto controverso, podendo ou não ter efeitos indesejáveis sobre o tempo para aparecimento do estro, dias abertos, taxa de concepção, sobrevivência embrionária e outros. Ferguson \& Chalupa (1989), revisando a literatura, demonstraram que o excesso de proteína degradável, em relação às exigências do animal, diminuía a taxa de concepção. Entretanto, estudando os efeitos do excesso de proteína nãodegradável, também em relação às exigências do animal, demonstraram que a diminuição da taxa de concepção era ainda maior. Postularam, também, que a percentagem de proteína bruta na dieta é um pobre indicador da adequação da nutrição protéica de vacas, explicando que outros fatores, como energia da dieta e produção da vaca, poderiam estar envolvidos na determinação das concentrações de uréia plasmática.

Kaim et al. (1983), Bruckental et al. (1989), Canfield et al. (1990), Elrod \& Butler (1991) e Larson et al. (1997) demonstraram diminuição significativa da taxa de concepção de grupos de vacas que apresentaram concentrações de NUS iguais a 17, 32, 19, 16 e $17 \mathrm{mg} / \mathrm{dL}$, respectivamente. De forma contrária, Folman et al. (1981), Howard et al. (1987) e Carroll et al. (1988) não demonstraram prejuízo na taxa de concepção, mesmo 
quando as concentrações de NUS chegaram a 15, 26 e 24 mg/dL. Em média, a depressão na taxa de concepção foi de 12 unidades percentuais, podendo chegar a 20\%, como descrito por Butler et al. (1995). De acordo com Pursley (1998), o intervalo entre partos ideal para máxima produtividade é de 12 meses. Quando esse intervalo se estende, além dos 13 meses, perdas econômicas significativas ocorrem. Segundo estimativas, as perdas econômicas, para intervalos entre partos que se estendem além do ideal de 12 meses, variam entre US\$3,00 a US\$5,50 de perda/vaca/dia, para vacas acima dos 100 dias vazios.

Melendez et al. (2000) avaliaram a associação entre NUL e risco de nãoprenhez após a primeira inseminação em um rebanho comercial na Flórida. Dois grupos de 515 e 558 vacas foram classificados como de alta $(17-25 \mathrm{mg} / \mathrm{dL})$ e de baixa concentração de NUL (6-16 mg/dL) com 30 dias antes da primeira inseminação. Um total de $158(30,6 \%)$ e $189(33,8 \%)$ vacas, respectivamente, foi diagnosticado como prenhe. Os pesquisadores demonstraram que vacas com alto NUL, que emprenharam durante o verão, apresentaram 18 vezes mais risco de não-prenhez comparadas às com baixo NUL, que emprenharam durante o inverno.

Rajala-Schultz et al. (2001) relataram que vacas com concentrações de NUL abaixo de 10mg/dL foram 2,4 vezes mais prováveis e vacas com NUL entre 10 e 12,7 foram 1,4 vez mais prováveis de estarem prenhes do que vacas com valores de NUL acima de 15,4 $\mathrm{mg} / \mathrm{dL}$. Seus resultados indicam que o aumento nas concentrações de NUL parece ser negativamente relacionado com fertilidade em vacas leiteiras. Eles também sugerem que as concentrações de NUL, que são adversamente associadas com fertilidade, podem ser menores que as reportadas anteriormente.

Também o número de partos parece afetar o efeito da nutrição protéica sobre a taxa de concepção. Kaim et al. (1983) e Bruckental et al. (1989) afirmaram que vacas mais velhas (multíparas) são mais afetadas por desbalanços protéicos, embora Carroll et al. (1988) aceitem que vacas de primeira cria (primíparas) sejam as mais suscetíveis.

Várias hipóteses foram propostas para explicar os efeitos do desbalanço protéico sobre o desempenho reprodutivo de vacas leiteiras (Staples et al., 1990). Essas 
hipóteses podem ser classificadas em dois grandes grupos, ou seja, de efeitos diretos e de indiretos. Quanto aos efeitos diretos, altas concentrações de uréia, amônia ou outro composto nitrogenado desconhecido agiriam sobre o eixo hipotalâmico-hipofisário-ovariano, sobre os gametas, sobre os embriões em desenvolvimento ou sobre o sistema imune, prejudicando o processo de fertilização, desenvolvimento embrionário ou implantação do embrião. Os efeitos indiretos do desbalanço protéico seriam efetuados por meio do aprofundamento do balanço energético negativo, seja pelo aumento da produção de leite promovido pela maior disponibilidade de proteína, seja pelo maior gasto com a detoxificação da amônia.

\section{c) Poluição ambiental}

A produção animal tem sido identificada como uma das principais fontes de poluição ambiental por nitrogênio (Thomann et al., 1994). Grandes quantidades de nitrogênio são levadas para as fazendas leiteiras pela compra dos alimentos. Muito desse nitrogênio permanece na fazenda, em vez de ser incorporado ao leite e tecido animal. Para prevenir a poluição ambiental e assegurar o uso eficiente dos nutrientes, um plano de manejo deve ser desenvolvido, determinando-se a quantidade de nutrientes entrando, saindo e permanecendo na fazenda (Klausner, 1993).

As vacas leiteiras secretam no leite, em média, 25-35\% do nitrogênio que consomem e quase todo o nitrogênio restante é excretado nas fezes e na urina (Chase, 1994). Van Horn et al. (1994) indicaram que a excreção total de nitrogênio nos dejetos pode ser determinada subtraindo-se a quantidade secretada no leite da quantidade consumida. Dessa forma, parte considerável do nitrogênio consumido é excretada juntamente com os dejetos animais, contaminando o ar pela amônia volatilizada e os rios e lençóis freáticos com o nitrato lixiviado (Tamminga, 1992; Van Horn et al., 1994 e Hof et al., 1997).

O nitrogênio consumido em excesso, as quantidades excessivas de proteína degradável no rúmen ou as dietas não adequadamente balanceadas para proteína degradável e não-degradável no rúmen, aminoácidos ou energia podem aumentar a excreção de nitrogênio nas fezes ou urina. À medida que a produção de leite aumenta, a excreção de 
nitrogênio nas fezes e urina por unidade de leite produzido diminui (St-Pierre and Thraen, 1999). Kohn et al. (1997) e Jonker et al. (2002b) demonstraram que a melhoria de $50 \%$ na eficiência de utilização do nitrogênio por um rebanho leiteiro pode reduzir a perda de nitrogênio para o ambiente em $40 \%$.

Ao desenvolver um modelo matemático para estimar a excreção urinária de nitrogênio por vacas em lactação, Jonker et al. (1998) concluíram que a cada aumento de 1 $\mathrm{mg} / \mathrm{dL}$ de NUS, havia excreção adicional de 12,54 gramas de nitrogênio/vaca/dia, equivalente a 78,4 g de proteína/vaca/dia.

\subsubsection{Fatores que afetam as concentrações de nitrogênio uréico no sangue e no leite}

\section{a) Consumo de proteína}

O NRC (1989) recomenda que a percentagem de proteína bruta (PB) na dieta de vacas leiteiras varie entre $12 \%$ e $18 \%$, dependendo do peso do animal e da produção de leite, podendo chegar a 19\% de PB na dieta de animais em início de lactação.

Vacas sob pastejo apresentam maiores concentrações de NUS, em virtude do maior consumo de proteína bruta, embora o consumo de altos teores de proteína degradável e/ou baixos teores de carboidratos não-estruturais também possam contribuir para isso (Payne \& Payne, 1987).

Staples et al. (1990) observaram aumento de 2,50 mg/dL de NUS para cada quilo adicional de proteína bruta consumida pelo animal. Entretanto, como o coeficiente de determinação foi baixo $\left(\mathrm{R}^{2}=0,31\right)$, esses pesquisadores chegaram à conclusão de que os valores de NUS não são bons indicadores do consumo de PB, mas, sim, bons indicadores da PB dietética não-aproveitada pelo animal. Portanto, mesmo vacas recebendo dietas com 19\% a $21 \%$ de PB poderiam ter valores de NUS ou NUL aceitáveis, se o nitrogênio fosse eficientemente utilizado por intermédio de um bom balanço de aminoácidos ou uma boa disponibilidade de energia ruminal. 
Cannas et al. (1998) observaram que a percentagem de proteína na dieta foi mais determinante para alterar as concentrações de NUL do que o próprio consumo total de PB. Jonker et al. (1998) afirmaram que altas concentrações de NUL são resultado de vários fatores nutricionais, incluindo não somente o excesso de proteína, mas também a quantidade inadequada de energia ou excesso de proteína degradável no rúmen, que podem diminuir a produção de leite e a eficiência de utilização de nitrogênio.

\section{b) Degradabilidade ruminal da proteína na dieta}

Os alimentos comumente utilizados para alimentar vacas leiteiras apresentam degradabilidade que pode variar entre $20 \%$ (farinha de sangue) e $100 \%$ (uréia). Portanto, dietas com a mesma percentagem de proteína bruta podem apresentar diferentes degradabilidades ruminais da proteína. O NRC (1989) recomenda que a degradabilidade da proteína na dieta seja entre $63 \%$ e $66 \%$, dependendo da produção e da fase de lactação da vaca.

Quantidades elevadas de proteína degradável aumentam as concentrações ruminais de amônia. Ao ultrapassar a capacidade de captura da amônia e de síntese de proteína pela microbiota ruminal, haveria aumento nas concentrações de NUS. Elevadas quantidades de proteína não-degradável, que fossem eficientemente absorvidas pelo trato digestivo, mas com inadequado perfil de aminoácidos, seriam em grande parte deaminadas pelo fígado para a síntese de glicose. Da mesma forma, seria observado aumento nas concentrações de NUS (Roseler et al., 1993).

Roseler et al. (1993) observaram que as concentrações de NUS ou NUL eram afetadas tanto pelo consumo de proteína degradável como de proteína não-degradável ruminalmente e em amplitudes semelhantes. Por sua vez, Godden et al. (2001b) mostraram que as concentrações médias de NUL de rebanhos apresentaram uma relação positiva com teores de proteína bruta, proteína degradável no rúmen (PDR) e proteína não-degradável no rúmen (PNDR). 


\section{c) Energia da dieta}

A uréia no leite fornece informações sobre as relações proteína/energia na dieta, mas parece pouco informar se as quantidades de alimento fornecidas estão apropriadas em relação às exigências (Oltner et al., 1985). Contudo, é provável que essa informação adicional possa ser obtida ao se monitorar variações no peso corporal, juntamente com avaliações de produção e composição do leite (Kaufmann, 1982).

Payne \& Payne (1987), Staples et al. (1990) e Jonker et al. (1998) reconhecem a importância do balanço entre energia e proteína para evitar altas excreções de nitrogênio pelo organismo. Roseler et al. (1993) observaram relação negativa entre consumo de energia e concentrações de NUS. Oltner \& Wiktorsson (1983) mostraram que variações na quantidade total de proteína ingerida não afetaram NUL, quando a relação proteína:energia foi mantida. Mas quando as alterações na composição da dieta aumentaram a relação proteína/energia, foram observadas maiores concentrações de NUL.

Carlsson \& Perhson (1994) observaram que quando as vacas foram alimentadas com quantidade constante de energia, mas crescente de proteína digestível, houve aumento na concentração de NUL. Desse modo, cada acréscimo de 60 g adicionais de proteína digestível para vacas recebendo energia adequada à sua exigência aumentou a concentração de uréia no leite em 0,2 a $0,3 \mathrm{mmol} / \mathrm{L}$. Esse aumento foi atribuído à degradação ruminal da proteína excedente à amônia, que não foi utilizada na síntese de proteína microbiana.

De acordo com os resultados de Hoffman \& Steinhöfel (1990), espera-se que vacas recebendo excesso de proteína, em relação à sua exigência, usem mais eficientemente a proteína para a síntese microbiana, se forem também alimentadas com mais energia. do que sua exigência. Cannas et al. (1998), trabalhando com ovelhas, observaram concentrações similares de NUL entre dietas com diferentes teores de energia. Mas dentro de cada teor de energia, NUL foi positiva e linearmente associado com a quantidade de proteína bruta dietária. Desse modo, os autores sugerem que NUL está mais associado à relação proteína:energia da dieta do que com o consumo de PB ou de energia. Godden et al. (2001b) mostraram que as 
concentrações médias de NUL de rebanhos apresentaram uma relação negativa com teores dietários de carboidratos não-fibrosos (CNF), relação CNF:PB e relação CNF:PDR.

\section{d) Manejo alimentar}

O manejo e o sistema de alimentação podem alterar as concentrações de NUS, cuja amplitude depende, principalmente, das condições da dieta. Rações completas diminuem o potencial para grandes variações nas concentrações de NUS ao longo do dia, uma vez que a dieta é consumida mais freqüentemente e em pequenas refeições (Roseler et al., 1993). Carroll et al (1988) mostraram que as concentrações de NUS foram menores em rebanhos alimentados com ração completa e em rebanhos que tinham alimento disponível continuamente, comparados com rebanhos que recebiam alimentos protéicos e energéticos separadamente ou com menor frequiência. Ferguson (1997) também relatou que maiores concentrações de NUL foram observadas em condições em que volumosos e concentrados foram administrados separadamente, quando comparadas a rações completas.

O estudo de Folman et al. (1981) sugeriu que as concentrações de uréia podem permanecer constantes no decorrer do dia em animais com alta frequiência ded alimentação ou com alimentação continua. Por sua vez, Godden et al. (2001b) mostraram que a concentração média de NUL de rebanhos não está associada ao manejo de alimentação (ração completa, frequiência de alimentação ou sincronia de fornecimento de volumoso e concentrado), mesmo em rebanhos alojados em "tie-stall" ou "free-stall". Esses últimos autores atribuem tais diferenças ao número relativamente pequeno de rebanhos usado em seu estudo ou à perda de variação e informação devida à interpretação dos dados, ao se tratar de dados médios de rebanhos e não mais dados individuais.

\section{e) Sistema de produção}

A concentração de uréia no leite foi maior quando as vacas estavam em pastejo do que quando confinadas (Kaufmann, 1982; Hoffman \& Steinhöfel, 1990; Carlsson \& Pehrson, 1993 e Carlsson et al, 1995), indicando excesso de formação de amônia no trato digestivo (Kaufmann, 1982). 
Carlsson \& Pehrson (1993) observaram que a média de concentração de uréia foi maior durante a estação de pastejo do que durante o período em que os animais foram confinados. Nos rebanhos com baixa concentração de uréia no leite, quando confinados ( $<2,24 \mathrm{mmol} / \mathrm{L})$, o aumento na média durante a estação de pastejo foi de, aproximadamente, 2,0 mmol/L, ao passo que, em rebanhos com alta concentração de uréia, quando confinados ( >6,0 mmol/L), houve uma pequena diminuição na concentração de uréia durante a estação de pastejo. Essas mudanças indicam que o pastejo resulta em mudança na quantidade e/ou disponibilidade de proteína dietária ou no balanço entre energia e proteína. Em média, os rebanhos com baixas concentrações de uréia, quando confinados, apresentaram baixas produções de leite. Eles, provavelmente, estavam subalimentados e, portanto, é provável que o aumento na uréia no leite seja devido ao maior consumo de proteína facilmente digestível.

Carlsson et al. (1995) concordam que essa diferença é devida, provavelmente, ao alto conteúdo de proteína bruta facilmente digestível na gramínea pastejada em relação ao conteúdo de energia. Eles também relataram que o efeito de estação do ano foi maior no final do que no meio da lactação. Explicam, ainda, que tal efeito pode ser devido às diferentes estratégias de alimentação suplementar aplicadas pelos fazendeiros durante a estação de pastejo. Em geral, espera-se que o pastejo forneça a maior parte dos nutrientes às vacas no final da lactação, tornando-se, as diferenças entre rebanhos de menor importância. Também observaram que as mudanças na concentração de uréia no leite foram muito mais regulares por toda lactação, quando as vacas foram confinadas do que quando pastejavam, talvez porque as mudanças no conteúdo nutricional da sua dieta foram muito mais regulares e controladas. Além disso, explicam que, em confinamento, o consumo de alimentos dos animais é, provavelmente, mais estável e também é mais fácil alimentá-los de acordo com suas exigências. $\mathrm{O}$ aumento nas concentrações de uréia no leite em animais primíparos, quando estavam em pastejo, durante os 3-4 últimos meses de lactação, foi, provavelmente, devido ao consumo excessivo de proteína bruta facilmente digestível, aliado ao fato de que sua produção estava declinando. 


\section{f) Estação do ano}

Carlsson et al. (1995) investigaram a influência da estação do ano sobre as concentrações de uréia no leite, comparando os resultados obtidos quando as vacas estavam confinadas com os obtidos quando pastejavam. Eles observaram que o formato das curvas foi mais regular quando as vacas estavam confinadas e as concentrações de uréia foram maiores no pico de lactação do que mais tardiamente. Durante a estação de pastejo, o padrão de concentração de uréia nas primíparas foi diferente, com um aumento entre o $9^{\circ}$ e o $11^{\circ}$ mês da lactação. Quando confinadas, as vacas multíparas apresentaram maior concentração de uréia do que as primíparas, mas, durante a estação de pastejo, não foram observadas diferenças entre os números de lactações.

Godden et al. (2001a) observaram que a concentração de uréia no leite foi maior no verão (julho a setembro), com vacas confinadas no Canadá. Sugeriram que a associação entre uréia no leite e estação do ano pode ser confundida com estágio de lactação e efeitos nutricionais. Moller et al. (1993) atribuíram a variação da uréia no leite às mudanças sazonais na proteína do pasto e nos componentes energéticos. O pasto de primavera na Austrália contém de 20-30\% de proteína bruta e de 5-20\% de carboidratos solúveis, criando, assim, uma alta relação proteína:energia, o que pode resultar em elevada concentração de uréia no leite. Arunvipas et al. (2002) reportaram elevadas concentrações de NUL no final do inverno/início do verão (março- abril) no Canadá, com os maiores valores ocorrendo em julho e agosto $(13,10 \mathrm{mg} / \mathrm{dL})$. 


\section{g) Momento de amostragem}

Os valores de NUL e NUS são também influenciados pelo momento de amostragem. Dietas com altas concentrações de proteína solúvel apresentam valores mais altos de NUS entre 1 e 2 horas após a alimentação, enquanto que, para dietas mais ricas em proteína não-degradável, os valores mais altos acontecem entre 6 e 8 horas após a alimentação (Roseler et al., 1993). Gustafsson \& Palmquist (1993) observaram maiores valores de NUL 4 horas após a alimentação, enquanto que, para Ferguson (1997), a concentração de NUL foi mais elevada entre 4 e 6 horas após a alimentação. Esse último autor observou que a concentração de NUL obtida na ordenha da tarde foi $2,1 \mathrm{mg} / \mathrm{dL}$ maior do que aquela obtida na ordenha da manhã, pois os animais eram alimentados às $11 \mathrm{~h}$. Staples et al. (1990) mostraram que amostras de sangue colhidas no momento da alimentação ou entre 6 e 7 horas após a alimentação apresentavam valores mais representativos de NUS ao longo do dia para vacas alimentadas com rações completas.

O leite da ordenha da manhã e da tarde diferem na concentração de uréia (Miettinen \& Junoven, 1990; Carlsson \& Bergström, 1994). Carlsson \& Bergström (1994) demonstraram que concentrações maiores de uréia no leite podem ser esperadas em amostras de leite coletadas poucas horas após a ordenha da manhã do que em amostras misturadas das ordenhas da manhã e da tarde. Tais diferenças foram atribuídas ao horário de alimentação dos animais. Desse modo, os autores sugerem que as amostras devem ser coletadas em quantidades similares de leite entre as ordenhas ou, ainda, que sejam coletadas sempre no mesmo horário, mantendo-se também o horário da alimentação.

\section{h) Diferença entre rebanhos}

Gustafsson et al. (1987) mostraram que a variação entre rebanhos foi responsável por $33 \%$ da variação total nas concentrações de uréia no leite, enquanto a diferença entre vacas individuais foi responsável por apenas 11\%. Assim, esses autores sugerem que as discrepâncias entre rebanhos são as principais causas de diferenças nas concentrações de uréia no leite. Segundo Carlsson et al (1995), importantes fatores envolvidos 
nessa variação podem ser a qualidade dos alimentos, o balanço entre volumosos e concentrados oferecidos, o balanço nutricional e o regime de alimentação usado, além de outros fatores menos importantes. A importância do efeito de rebanho reforça o potencial valor das análises das concentrações de uréia no leite na avaliação prática de dietas para vacas leiteiras.

Godden et al. (2001a) relataram uma associação positiva, mas não-linear entre uréia no leite e produção de leite de vacas individuais. Mas Godden et al. (2001b) não encontraram associação entre a uréia média no leite dos rebanhos e a produção média dos rebanhos, ou com a produção média corrigida para gordura e proteína. Desse modo, recomendaram que a uréia no leite seja interpretada no âmbito de grupo de animais ou rebanho e não no âmbito de vacas individuais, por causa da relativa inacurácia inerente aos resultados das análises por infravermelho e da grande variabilidade entre vacas sobre as concentrações de uréia no leite.

\section{i) Método de análise}

A quantificação de nitrogênio uréico pode ser realizada por meio de métodos diretos (enzimático e colorimétrico) e indiretos (NIRS). No método enzimático, a uréia é hidrolisada à amônia pela urease. Em seguida, a amônia é convertida em um composto colorido (indofenol) pela sua reação com hipoclorito e fenol. No método colorimétrico, a uréia é convertida em um cromogênio pela sua reação com diacetil monoxima e cloreto férrico. Posteriormente, em ambos os métodos, a reação de cor é quantificada por meio de um colorímetro. Não têm sido observadas diferenças significativas para valores obtidos entre métodos colorimétricos ou enzimáticos (Staples et al., 1990). A desproteinização do leite é necessária para ambos os métodos e a desproteinização do plasma é mais importante para melhorar a precisão do método colorimétrico (Marsh et al., 1965).

O NIRS (espectrometria de infravermelho proximal) é uma metodologia indireta que não tem sido recomendada para amostras de leite obtidas diretamente do tanque, por apresentar menor acurácia que métodos químicos diretos (Kohn, 2000). 


\section{j) Mastite}

Poucos trabalhos foram publicados que descrevem a relação entre contagem de células somáticas (CCS) e nitrogênio uréico no leite (NUL).

Wolfschoon-Pombo (1981) relatou que a mastite pode influenciar a concentração de uréia na amostra do quarto infectado. Harmeyer \& Martens (1980) observaram menores concentrações de uréia no leite em quartos de caprinos com elevada CCS. Um estudo no Canadá, realizado por Ng-Kwai-Hang et al. (1985), reportou uma associação positiva entre CCS e proteína verdadeira do leite. Os pesquisadores ainda relataram pequena, mas significativa, associação positiva entre CCS e teores de nitrogênio não-protéico do leite.

DePeters \& Ferguson (1992), em revisão de estudos prévios, também relataram que o leite de glândulas mastíticas apresentou menor percentagem de caseína e maior de proteína não-caseína. Eles sugerem que os produtos da ruptura da caseína contribuem para a fração de proteína do soro no leite mastítico. Entretanto, Eicher et al. (1999) não observaram influência da contagem de células somáticas (medida, indiretamente, com o uso do "California Matistis Test") sobre as concentrações de uréia no leite, nem mesmo quando as amostras foram coletadas de quartos diferentes.

Arunvipas et al. (2002) observaram que, a cada aumento de uma unidade no escore linear, a concentração de NUL diminui em 0,4 mg/dL. Godden et al. (2001a) também relataram uma associação negativa, mas não-linear, entre a uréia no leite e o escore linear da contagem de células somáticas das vacas. Segundo os pesquisadores, tal associação negativa pode não represent ar uma relação biológica entre esses dois parâmetros, mas, sim, ser um artefato do instrumento de calibração. Porém, esses autores não encontraram associação entre o escore linear médio da CCS dos rebanhos e a sua uréia média no leite. Desse modo, sugeriram que essa discrepância pode ser devida à perda de variação quando os escores lineares são interpretados no âmbito de rebanho.

Apesar da relação negativa entre uréia no leite e CCS das vacas, Godden et al. (2001a) postularam que os dados de uréia no leite devem ser interpretados no âmbito de 
grupo e não no de vacas individuais, como sugerido por outros pesquisadores (Oltner et al., 1985; Broderick \& Clayton, 1997; Cannas et al., 1998 (com ovelhas); Schepers \& Meijer, 1998). Portanto, a menos que uma grande proporção de vacas no grupo ou rebanho tenha alta CCS, a uréia média no leite do rebanho não deveria ser muito afetada pela CCS (Godden et al., 2001a).

\section{h) Outros}

Jonker et al. (1998) estudaram os efeitos da produção de leite, percentagem de gordura no leite, peso vivo do animal e ordem de partos sobre as concentrações de NUL. Esses pesquisadores observaram concentração média de NUL de 13,51 mg/dL para rebanhos com potencial de produção de $10.000 \mathrm{~kg}$ de leite/vaca/lactação (305 dias), sendo que esse valor poderia aumentar ou diminuir em $2,85 \mathrm{mg} / \mathrm{dL}$ para cada aumento ou diminuição, respectivamente, de $2.000 \mathrm{~kg}$ de leite/vaca/lactação, ou seja, uma variação entre 10,66 e 16,36 mg/dL. Entretanto, eles aceitam que o efeito da produção de leite sobre as concentrações de NUL é resultado do confundimento entre produção de leite e relação proteína/energia na dieta, uma vez que esses fatores são positivamente correlacionados.

Para a percentagem de gordura do leite, a alteração de 0,5 unidade percentual de gordura resulta em alteração da concentração de NUL de $1,70 \mathrm{mg} / \mathrm{dL}$, com maior concentração de NUL para maiores teores de gordura. Cada $50 \mathrm{~kg}$ de peso vivo representa uma variação de $0,42 \mathrm{mg} / \mathrm{dL}$ na concentração de NUL, sendo maior a concentração quanto maior for o peso da vaca. Também o número de partos alterou esse parâmetro, uma vez que mudanças nessa variável modificaram as concentrações de NUL em 0,45 mg/dL. Desse modo, primíparas apresentaram maiores valores que as multíparas. Em geral, a maior exigência de nitrogênio aumentou a concentração lactacional de NUL (Jonker et al.,1998).

Jonker et al. (1999), além de estudarem as variáveis citadas anteriormente, incluíram a percentagem de proteína do leite. Concluíram que o aumento de 0,3 unidade percentual de proteína bruta no leite diminui a concentração de NUL em 1,2 mg/dL. Esse efeito é explicado pelo fato de o aumento na percentagem de proteína no leite direcionar o 
nitrogênio consumido para proteína do leite. As concentrações-alvo médias estimadas pelo modelo desenvolvido por tais pesquisadores foram de 11,7, 12,8 e 13,0 mg/dL para as vacas de primeira, segunda e terceira lactações, respectivamente. Comparativamente, as concentrações médias reais de NUL foram de 16,3, 16,8 e 16,2 mg/dL. Essas concentrações de NUL ocorreriam quando a percentagem de PB estimada das dietas consumidas pelas vacas fosse, em média, de 17\% (aproximadamente) para todas as lactações, mas o NRC (1989) recomenda menores quantidades de PB, dependendo do número de lactações.

Tais autores relataram também que as diferenças nas concentrações-alvo de NUL, encontradas entre os números de lactações, eram devidas às maiores exigências, estimadas pelo NRC (1989), para as vacas de primeira e segunda lactações, a fim de permitir o crescimento. Os autores, ainda, afirmaram que a concentração lactacional média de NUL para seu modelo foi mais sensível ao nível de alimentação relativo às exigências e à produção de leite e menos ao peso corporal e número de lactações. Entretanto, Carlsson et al. (1995), Schepers \& Meijer (1998), Eicher et al. (1999) e Arunvipas et al. (2002) não reportaram diferenças na concentração de uréia no leite entre animais primíparos e multíparos.

Godden et al. (2001a) relataram associação positiva, mas não-linear, entre uréia no leite e produção de leite, produção de leite corrigida para 3,5\% de gordura e, também, corrigida para energia (3,5\% de gordura e 3,2\% de proteína). Eles propõem que, apesar de a relação parecer similar entre a uréia no leite e essas três medidas de produção de leite, o ajuste do modelo foi melhor quando a produção corrigida para energia foi usada.

Oltner \& Wiktorsson (1983), Oltner et al. (1985) e Broderick \& Clayton (1997) sugeriram que o efeito da produção de leite sobre as concentrações de NUL é causado pela forte correlação entre produção de leite e relação proteína/energia na dieta. Chalupa (1984) e Oldham (1984) atribuíram a associação positiva entre uréia no leite e produção de leite como resultado dos maiores teores de proteína dietária fornecidos. A proteína suplementar pode aumentar a produção de leite por fornecer mais aminoácidos para a síntese de proteína do leite, por aumentar a energia disponível pela deaminação dos aminoácidos ou por alterar a eficiência de utilização dos nutrientes absorvidos (Chalupa, 
1984). MacLeod et al. (1984) destacaram que o aumento nos teores de proteína na dieta teve o efeito de aumentar o consumo de matéria seca, resultando, assim, em um efeito indireto no aumento do consumo de energia.

Trevaskis \& Fulkerson (1999) observaram que a produção de leite de vacas em pastejo foi negativamente relacionada à concentração de uréia no leite e atribuem esse fato a um resultado de diluição. Uma outra possível explicação para essa relação negativa seria o fato de que a taxa energética, associada à conversão de quantidades excessivas de amônia em uréia, pode contribuir para diminuir a energia disponível para produção de leite (Nelson, 1995), desviando, assim, essa energia para detoxificação da amônia (Van Soest, 1994).

\subsubsection{Padrões de referência e tamanho da amostra}

Jonker et al. (1998) defendem que os padrões de referência das concentrações de NUL devem levar em conta o potencial de produção do rebanho, o número de partos médio, o peso vivo, a percentagem de gordura no leite e o número de dias em lactação. Defendem, também, que a produção do rebanho é o principal fator a influenciar esse parâmetro, uma vez que os valores médios de NUL foram iguais a 10,66, 13,51 e 16,36 $\mathrm{mg} / \mathrm{dL}$ para rebanhos, produzindo, respectivamente, $8.000,10.000$ e $12.000 \mathrm{~kg}$ de leite/vaca/lactação. Dessa forma, os padrões de referência podem variar entre 10 e 16 mg/dL, dependendo da produtividade do rebanho. Em virtude da variação observada, Jonker et al. (1998) recomendam que, pelo menos, 10 vacas sejam amostradas para produzir resultados acurados.

Broderick \& Clayton (1997), ao revisarem a literatura, observaram que a concentração média de NUL foi de 14,8 mg/dL e o desvio-padrão, de 2,07 mg/dL. Considerando um intervalo de confiança de $95 \%$, os autores propuseram que, para se obter variação de até $1,0 \mathrm{mg} / \mathrm{dL}$, deveriam ser amostradas 16 vacas, enquanto que, para se obter variação de até 2,0 mg/dL, 4 vacas amostradas seriam suficientes. Por sua vez, Ferguson (1997) recomendou que, pelos menos, 8 vacas sejam amostradas para produzir resultados 
confiáveis, uma vez que a concentração média de vários rebanhos dos Estados Unidos foi de $14 \mathrm{mg} / \mathrm{dL}$ e o desvio-padrão, de 4,03 mg/dL.

Quanto aos parâmetros reprodutivos, o valor de NUS que diminuiu a taxa de concepção entre os diferentes experimentos variou bastante. Em cinco experimentos em que a taxa de concepção foi diminuída (Kaim et al., 1983; Bruckental et al., 1989; Canfield et al., 1990; Elrod \& Butler, 1991; Larson et al., 1997), os valores de NUS excederam 16 mg/dL. Porém, em dois casos (Howard et al., 1987; Carroll et al., 1988) não foram observados efeitos deletérios sobre a concepção, mesmo com concentrações superiores a $16 \mathrm{mg} / \mathrm{dL}$. Por esse motivo, Staples et al. (1990) afirmaram que os valores de NUS não são indicadores confiáveis de risco potencial para ocorrência de desordens reprodutivas, embora valores acima de $16 \mathrm{mg} / \mathrm{dL}$ possam ser utilizados como sinal de alerta.

\subsubsection{Análise de leite do tanque de expansão}

Refsdal (1983) sugeriu que a concentração de uréia no leite do tanque de expansão poderia ser usada como um indicador da eficiência nutricional de uma dieta oferecida a um rebanho, pois encontrou uma boa correlação entre a média de uréia no plasma dos rebanhos e a uréia no leite dos tanques, levando-se em conta que esses tanques compreendiam o leite da ordenha da manhã e da tarde.

Carlsson et al. (1995) encontraram forte correlação ( $r=0,93)$ entre as concentrações de NUL analisadas de amostras coletadas do tanque de expansão e a concentração média de cada vaca, sendo que essa concentração foi calculada pela fórmula $\sum \mathrm{C} i^{*} \mathrm{Y} i$ / $\sum \mathrm{Y} i$, em que $\mathrm{C} i$ a concentração de uréia no leite de cada vaca $i$ e $\mathrm{Y} i$ a produção de leite da vaca $i$, sem correção para gordura. Eles sugerem que as concentrações de uréia no leite do tanque são uma medida satisfatória da concentração média de uréia do rebanho.

\subsection{Outros fatores que afetam a composição do leite}


Em virtude da nova legislação brasileira de qualidade do leite e do pagamento diferenciado pela indústria, a demanda dos produtores brasileiros por análises de leite é crescente. Assim, a amostragem de leite dos rebanhos vem sendo realizada mensalmente, para determinação da concentração de gordura, proteína, lactose e sólidos totais, contagem de células somáticas e, mais recentemente, nitrogênio uréico. Conseqüentemente, a indústria pode fazer um pagamento de leite adequado ao produtor e este, por sua vez, pode avaliar a situação sanitária e nutricional de seu rebanho. Entretanto, o procedimento de amostragem na fazenda, o transporte e a conservação do leite, até o momento de sua análise, são de extrema importância para garantir sua estabilidade física e química, de modo a gerar resultados confiáveis de seus componentes.

De acordo com Kroger (1985), o meio ideal de conservação das amostras de leite por vários dias, antes da análise, é a refrigeração, o mais próximo possível do ponto de congelamento, sem, no entanto, congelar as amostras. Isso previne o crescimento de bactérias e todas as mudanças físicas e químicas que o seguem. A formação de cristais de gelo, geralmente, leva à ruptura das estruturas físicas do leite, dificultando a retirada de subamostras representativas (alíquotas).

A conservação ideal também assume e assegura proteção da ruptura mecânica dos glóbulos de gordura, que resultaria na formação de gordura livre. O leite contendo gordura livre não é adequado para a retirada de subamostras acuradas e reproduzíveis. Desse modo, a quebra dos glóbulos de gordura é prevenida pela mínima agitação. Para o transporte das amostras, a mínima agitação é alcançada pelo enchimento completo dos frascos para coleta, sem inclusão de ar (Kroger, 1985).

Segundo Kroger (1985), quando a refrigeração da amostra não é possível ou praticável, deve-se recorrer à conservação química. A exigência mínima para que um conservante químico seja adequado é assegurar a reprodutibilidade das análises. Isso significa que a amostra de leite deve manter sua composição original, do momento da ordenha até a análise. 


\subsubsection{Tempo de armazenamento}

Read Jr. et al. (1969) congelaram amostras de leite a $-20^{\circ} \mathrm{C}$, armazenando-as por $3,7,14$ e 28 dias. Os resultados obtidos mostraram que o congelamento das amostras reduziu os valores do teste de mastite de Wisconsin (WMT), da contagem microscópica direta de células somáticas e da contagem eletrônica. Essas reduções variaram de 13 a 84\%, quando comparadas às leituras de $0 \mathrm{~h}$, antes do congelamento.

Amostras de leite de rebanhos também foram testadas com dicromato de potássio em concentrações de 0,3 a $0,4 \%$ por até 10 dias de refrigeração. Contudo, diferenças foram observadas entre diferentes raças. Com amostras de vacas Jersey, os decréscimos na gordura foram demonstrados mais rapidamente do que nas amostras de vacas Holandesas. A acidez se desenvolveu em amostras armazenadas em temperatura ambiente por um período prolongado (Minzner \& Kroger, 1974).

Em um estudo usando Milko-Tester MK-III ${ }^{\circledR}$ e conservando amostras de leite por 3 dias em temperatura ambiente, com dicromato de potássio, $\mathrm{HgCh}$ ou formaldeído, os resultados mostraram que, por períodos mais longos, apenas as amostras conservadas com dicromato produziram resultados satisfatórios (Wolfschoon-Pombo, 1978).

Ng-Kwai-Hang \& Hayes (1982) estudaram os efeitos do armazenamento das amostras de leite conservadas com dicromato de potássio sobre os resultados das análises de gordura, proteína e caseína. O conteúdo de gordura não foi alterado quando as amostras foram armazenadas por até 10 dias. Por outro lado, o conteúdo de proteína, analisado pelo "Milko-Scan 300®", mostrou aumento de 3,14 para 3,24\% entre os dias 1 e 4, diminuição de 3,24 para 3,04\% entre os dias 4 e 7 e outro aumento de 3,04 para 3,18\% entre os dias 7 e 10. A análise de proteína pelo procedimento "dye-binding" resultou em concentrações mais elevadas do que pelo método infravermelho. De acordo com os autores, essa diferença foi devida àreação do dicromato de potássio com a solução utilizada no procedimento. Os efeitos do armazenamento sobre a análise de proteína pelo método "dye-binding" mostraram menor 
variação do que pelo infravermelho, apesar da superestimação dos valores. Essa superestimação também foi relatada por Ashworth et al. (1960).

Entretanto, Kroger (1971) reportou depressões na gordura do leite de 0,03, 0,13, 0,18 e 0,39 unidade percentual, após 3, 5, 7 e 12 dias, respectivamente, de amostras conservadas com dicromato de potássio, analisadas pelo Milko-Tester Automatic ®. Concentrações de $0,08 \%$ até $0,8 \%$ de dicromato foram suficientes para manter o conteúdo de gordura do leite das amostras testadas em até 3 dias, quando armazenadas a 21-27 $\mathrm{C}$. Observa-se, então, que o decréscimo no conteúdo de gordura maior que 0,1 unidade percentual ocorreu após o 5 dia. Esse efeito se tornou mais pronunciado, à medida que o tempo de armazenamento aumentou. $\mathrm{O}$ autor acredita que seja devido a mudanças na estrutura física com o envelhecimento das amostras de leite. A concentração do conservante parece não ter influenciado os resultados de decréscimo de gordura.

Resultados conflitantes sobre o armazenamento das amostras para análise de NUL foram encontrados na literatura. Oltner \& Sjaunja (1982), Miettinen \& Juvonen (1990) e Carlsson \& Bergstrom (1994), usando métodos indiretos de análise química, relataram que as concentrações de uréia no leite não sofreram mudanças por até 7 dias, quando refrigeradas $\left(4^{0} \mathrm{C}\right)$. Entretanto, Eicher et al. (1999) observaram maiores concentrações de uréia após 1 semana de refrigeração (8,1\% de variação), em amostras analisadas por infravermelho.

\subsubsection{Método de armazenamento}

Em um estudo de Monardes et al. (1996), em condições de verão, foi comparado o desempenho de conservantes para leite em diferentes métodos de armazenamento. Os conservantes utilizados foram: a) dicromato de potássio em tabletes de $156 \mathrm{mg}$; b) microtabletes de bronopol (10 mg de bronopol); c) bronopol líquido (contendo inibidor de levedura e fungo). Os métodos de armazenamento foram: 1) sem refrigeração (amostras transportadas e armazenadas no laboratório à temperatura ambiente); 2) refrigeração no laboratório (amostras refrigeradas a $1-5^{\circ} \mathrm{C}$, da chegada ao laboratório até a 
análise); 3) transporte e refrigeração no laboratório (amostras permaneceram à temperatura ambiente na casa do coletor até o transporte (4-6h), foram transportadas refrigeradas a $1-5^{\circ} \mathrm{C}$ e, então, refrigeradas no laboratório até a análise); 4) refrigeração completa (amostras refrigeradas em até $3 \mathrm{~h}$ após a coleta, refrigeradas durante o transporte e no laboratório até a análise). As amostras foram armazenadas por 3 ou 7 dias. As análises de gordura e proteína foram realizadas pelo equipamento infravermelho "Multispec II ${ }^{\circledR}$ " (Foss Food Technology) e a CCS pelo "Fossomatic $21{ }^{\circledR} "$ ". Os resultados mostraram que, em geral, amostras conservadas com bronopol (líquido ou microtabletes) apresentaram valores maiores para conteúdo de gordura e proteína do que amostras conservadas com dicromato de potássio. Valores menores de gordura foram observados nas amostras armazenadas por mais tempo (7 dias) comparadas às analisadas com 3 dias. $\mathrm{O}$ decréscimo foi mais acentuado nas amostras nãorefrigeradas. Sob os métodos de manuseio das amostras de leite, a refrigeração, durante todo o processo (desde a amostragem até a análise), parece ideal para evitar reduções dos valores de gordura.

Chavez et al. (1991) relataram que amostras com conservantes químicos, quando refrigeradas, não apresentaram variações em sua composição com o decorrer dos dias, mas aquelas mantidas à temperatura ambiente ou a temperaturas elevadas apresentaram valores inferiores.

Godden et al. (2000) observaram que as concentrações de uréia no leite permaneceram inalteradas em amostras congeladas por até 3 dias, mas foram elevadas em amostras congeladas por 4 ou 7 dias $\left(-18^{\circ} \mathrm{C}\right)$. Desse modo, sugerem que o congelamento das amostras por curto período (exemplo, por uma noite), durante o transporte para o laboratório, não deve interferir na acurácia dos resultados de uréia no leite produzidos por análises por infravermelho. Por sua vez, Eicher et al. (1999) observaram maiores concentrações de uréia, após 1 mês de congelamento (26,7\% de variação), em amostras analisadas por infravermelho. 


\subsection{Estudo da curva de lactação}

As curvas de lactação, ao descreverem a produção de leite do animal, servem como importante ferramenta de tomada de decisão para o manejo de vacas em lactação. No entanto, considerando-se a possibilidade de serem alteradas por outros fatores, é importante conhecer tais efeitos, possibilitando que, no futuro, sejam desenvolvidas ferramentas computacionais de tomada de decisão para uso nas fazendas.

A curva de lactação é definida pelo gráfico da produção diária de leite ao longo do tempo (Kellogg et al., 1977). A produção de leite das vacas aumenta do parto até o pico de produção num período de poucas semanas; segue-se, então, um declínio gradual até a secagem (Batra, 1986). Assim, o estudo da curva de lactação permite conhecer melhor o desenvolvimento desse processo fisiológico, favorecendo a tomada de decisões com relação ao manejo das vacas lactantes, com base no estágio de lactação em que se encontram (Costa et al., 1982).

Segundo Keown \& Van Vleck (1973), a curva de lactação pode ser dividida em três segmentos:

1. do dia de parição até o pico da lactação, que é não-linear e aumenta a taxa declinante até o pico;

2. do pico até, aproximadamente, 270 dias de lactação, que é linear e declina a taxa constante;

3. ao final da lactação, em que a produção declina a taxa crescente.

As curvas de lactação podem ser geradas e estudadas por meio de modelos matemáticos. Vários modelos têm sido propostos, ao longo dos anos, para descrever a curva de lactação, entre eles, o modelo baseado na função gama incompleta, desenvolvido por Wood (1967). O modelo gama tem a habilidade de gerar curvas de muitos formatos e pode formar curvas de lactação afetadas por diferentes fatores biológicos e ambientais (Congleton \& Everett, 1980).

O modelo matemático é dado por: 
$y_{t}=A t^{b} e^{-c t_{i}}$

sendo que $y_{t}$ a produção diária na data $t ; A, b$ e $c$ os parâmetros da curva de lactação (constantes); $e$ a base dos logaritmos naturais.

As constantes são determinadas pelo método de quadrados mínimos. A constante $A$ é um fator de escala geral associado à produção de leite no início da lactação (Wood, 1967), responsável por abaixar ou elevar toda a curva de lactação, não alterando, entretanto, seu formato geral (Batra, 1986). O fator $b$ é um índice que mede a capacidade de a vaca utilizar energia para a produção de leite ou, matematicamente, representa a fase de ascensão da curva no início da lactação (Shanks et al., 1981), sendo o principal responsável pela determinação do formato da curva antes do pico de lactação (Congleton \& Everett, 1980). A constante $c$ representa a taxa de declínio da curva (Shanks et al., 1981).

Segundo Ali \& Schaeffer (1987), os parâmetros das curvas, geralmente, são estimados por regressão simples, o que ignora a covariância entre as produções diárias. Entretanto, esses autores, ao testarem o uso da covariância, concluíram que sua utilização não torna as predições mais acuradas.

As curvas de lactação que seguem o modelo gama são geradas pela regressão linear da transformação logarítmica da função gama incompleta.

A persistência da lactação é indicada por $\mathrm{c}^{-(\mathrm{b}+1)}$, a data do pico é dada por b/c e a produção no pico, por $\mathrm{A}(\mathrm{b} / \mathrm{c})^{\mathrm{b}} \mathrm{e}^{-\mathrm{b}}$.

Se a porção inicial da curva é curta ou falta informação nessa porção, a regressão linear da equação log-transformada estimará um $b$ negativo. Com valores positivos para $A$ e $c$, ambos os componentes da equação $t^{b}$ e $e^{-c t}$ declinarão com maiores valores de $t$. A curva resultante terá uma taxa negativa em todos os dias e a data do pico previsto de produção (b/c) ocorrerá antes da parição. Curvas com esse formato são responsáveis por grande parte da variação na produção de leite prevista para a primeira semana de lactação (Congleton \& Everett, 1980). 
Analisando 13 modelos matemáticos, Rook et al. (1993) concluíram que o modelo de Wood e o modelo Mitscherlich-Exponencial representavam melhor a curva de lactação que os outros modelos.

De acordo com Batra (1986), os fatores que afetam a forma da curva de lactação são: ambiente, ano de parição, estação de parição, idade ao parto e duração dos períodos seco, de serviço e de gestação. Além desses, o estado sanitário do animal, como a ocorrência de mastite e outros distúrbios, podem afetar a curva de lactação.

Em 1923, Sanders (citado por Batra, 1986) reportou que a diferença na forma da curva de lactação entre vacas é maior que a diferença entre as curvas da mesma vaca em diferentes parições, mostrando efeito genético sobre a curva. Touchberry (1974), citado por Costa et al. (1982), observou que o pico de produção e a própria forma da curva de lactação dependem da condição física da vaca no parto, de seu potencial genético, estado de saúde e regime alimentar nos vários estágios de lactação.

As estimativas da repetibilidade e herdabilidade de dados de produção mensal aumentam com o estágio de lactação até o quinto ou sexto mês e, a partir daí, declinam. Isso sugere que o início e o final da lactação são mais sujeitos à variação ambiental temporária que o meio da lactação, sendo esse último mais influenciado por fatores genéticos e alterações ambientais permanentes (Van Vleck \& Henderson, 1961a).

A idade da vaca e a estação do parto influenciaram significativamente as produções mensais e totais de leite (Van Vleck \& Henderson, 1961b; Miller et al., 1967; Costa et al., 1982 e Neto et al., 1998;). A curva de lactação de vacas mais jovens é caracterizada por menores produções ao longo da lactação, mas com decréscimos mensais reduzidos, o que garante elevada persistência (Miller et al., 1967; Costa et al., 1982 e Batra, 1986).

Matematicamente, o formato mais baixo e mais suave das curvas de lactação de animais primíparos é evidenciado por menores coeficientes $\log (a), b$, e $c$ da função gama (Batra, 1986). Os efeitos da idade sobre a curva de lactação diferem em função do estágio de 
lactação (Miller et al., 1967). Aparentemente, ocorre um maior efeito inibidor provocado pela gestação em animais mais velhos, devido às maiores produções (Costa et al., 1982). Com o aumento da produção total, de acordo com a idade da vaca no parto, a primeira fase de lactação é mais importante, por apresentar maior contribuição para a produção total de leite no período. Em consequiência, a contribuição dos últimos meses é bem menor, o que, de certa forma, está relacionado com a persistência, que tende a diminuir com a idade (Costa et al., 1982). Esses mesmos autores, ainda, citam que uma razão para o rápido declínio da produção de leite no final da lactação é o desenvolvimento do feto.

A introdução na função gama incompleta de lactações com períodos variáveis entre a parição e a primeira coleta de dados pode influenciar o formato da curva de lactação (Congleton \& Everett, 1980).

Estudos de curvas de lactação com dados de rebanhos comerciais são bastante problemáticos, uma vez que o intervalo entre controles é longo, gerando vícios nas estimativas dos parâmetros e nas estatísticas deles derivadas, principalmente, na fase anterior ao pico de lactação (Ribeiro et al., 1998a,b).

Ao introduzir observações mensais no modelo gama, o erro em prever a produção acumulada em 305 dias de lactação aumenta em torno de 247 a 300\%, quando comparado com as curvas que receberam produções diárias (Congleton \& Everett, 1980).

\subsection{Avaliação de modelos matemáticos}

A meta da avaliação de modelos matemáticos é determinar a acurácia, a precisão e a robustez das predições dos modelos e identificar pontos fracos que necessitem de pesquisa adicional. Segundo Kohn et al. (1998), a avaliação da metodologia deve ser altamente organizada e rigorosamente estruturada, para assegurar que todas as situações sejam bem representadas. Os resultados da avaliação devem ser bem documentados e auxiliar os usuários no entendimento das limitações e do poder do sistema. Também é indicado que a avaliação não seja coordenada pela mesma pessoa que coordena o desenvolvimento do 
modelo, mas que esses pesquisadores continuem a participar da avaliação para explicar o apropriado uso do modelo e suas suposições.

A acurácia e a precisão dos modelos são determinadas ao se comparar as predições com os dados observados. Os dados usados devem refletir os objetivos do modelo; se o modelo deve ser usado no campo, os dados devem ser obtidos de animais em condições para as quais o modelo é recomendado. Na avaliação da extensão de suas aplicações, o banco de dados para avaliação do modelo deve ser independente do banco de dados usado no seu desenvolvimento. Por exemplo, os mesmos dados não podem ser usados no desenvolvimento e na avaliação do modelo. A análise deve representar todas as situações possíveis para as quais o modelo deve ser recomendado (ex. níveis de produção, tipos de alimento, etc.) (Kohn et al., 1998).

\subsubsection{Hipótese}

Segundo Kohn et al. (1998), a avaliação do modelo inclui um componente estatístico rigoroso. Nos estágios iniciais de desenvolvimento do modelo, a hipótese de nulidade é aquela em que o modelo não prediz os resultados reais de campo. Qualquer relação positiva entre observações e predições garante a rejeição dessa hipótese e uma avaliação favorável do modelo. Avanços adicionais na pesquisa de modelagem necessitam de exame mais crítico do modelo. Uma segunda hipótese de nulidade é aquela em que o modelo prediz consistentemente os resultados observados. Uma rejeição dessa segunda hipótese indica vieses potenciais no modelo. Finalmente, os modelos que diferirem em complexidade devem ser comparados entre si, de forma a comprovar se uma complexidade maior é realmente necessária. Nesse caso, a hipótese nula testada seria que o erro da predição de um modelo não difere do erro de outro. A ausência em rejeitar essa hipótese garante o uso do modelo mais conveniente, ou seja, o mais simples para as condições de uso. 


\subsubsection{Análise de Sensibilidade}

Geralmente, os modelos que são relevantes em nutrição animal são avaliados por regressão das respostas observadas em função das respostas preditas, gerando, por exemplo, o coeficiente de determinação $\left(\mathrm{R}^{2}\right)$. Contudo, a informação fornecida por tal análise é ambígua e falta sensibilidade (Mitchell, 1997). Alternativamente, utiliza-se a raiz quadrada média do erro de predição (RQMEP), que é uma medida de quanto as predições se adequam bem aos dados observados (Bibby \& Toutenburg, 1977).

Para a avaliação de modelos, a acurácia, a precisão e a robustez são medidas. A acurácia e a precisão dos modelos são determinadas pela comparação dos dados preditos com os observados. A robustez é determinada pela comparação dos valores preditos menos os observados (vieses) com outros fatores estudados (Kohn et al., 1998).

A acurácia dos modelos é avaliada por meio do viés médio. $\mathrm{O}$ viés é a diferença entre o valor predito pelo modelo e o valor observado e representa a inacurácia média das predições do modelo. Portanto, o modelo mais acurado é aquele que possui um viés médio mais próximo do valor zero (Kohn et al., 1998). A acurácia é medida pela fórmula a seguir:

Viés médio $=\frac{\sum(\text { predito }- \text { observado })}{n^{o} \text { observações }}$

A precisão é uma medida de dispersão entre os valores preditos e observados, ou seja, a variabilidade média da distância entre o valor predito e o valor observado. Ela pode ser avaliada pela raiz quadrada média do erro de predição (RQMEP) ou pelo erro residual. A RQMEP ou "root mean square prediction error" (RMSPE) (Bibby \& Toutenburg, 1977) é uma medida de quanto as predições se adequam bem aos dados observados e é calculada pela seguinte fórmula:

$\mathrm{RQMEP}=\sqrt{\frac{\sum(\text { predito }- \text { observado })^{2}}{n^{o} \text { observações }}}$ 
Esse termo é a raiz quadrada da estimativa da variância dos valores preditos em função dos valores observados (Kohn et al., 1998).

Entretanto, toda vez que o viés médio for alto (falta de acurácia), há uma superestimativa da falta de precisão, ou seja, uma superestimativa da RQMEP, uma vez que a distância média entre o valor predito e o observado leva também ao aumento da variabilidade entre o predito e o observado. Portanto, a precisão é mais bem avaliada quando a RQMEP é corrigida para falta de acurácia (Rodrigues, $2002^{1}$ ). Esse novo valor é chamado de erro residual, que é definido como o erro restante no modelo de predição, excluindo-se o erro devido ao viés médio (Kohn et al., 1998). É também referido como o erro de predição, excluindo-se o viés médio, sendo obtido pela fórmula:

Erro residual $=\sqrt{\left[R Q M E P^{2}-(\text { viésmédio })^{2}\right.}$

A regressão dos vieses (valores preditos menos valores observados) contra os valores observados, gerando o viés linear, pode ser usada para identificar se a magnitude do viés aumenta, diminui ou não existe com a magnitude dos valores observados (Bibby \& Toutenburg, 1977).

A robustez é a caracterização do modelo que menos é influenciado por outros fatores selecionados. É obtida da regressão dos vieses (valores preditos menos valores observados) contra variáveis diferentes, passíveis de serem identificadas na experimentação (Rodrigues, 2002).

\subsubsection{Modelos para estimar as concentrações de nitrogênio uréico no leite}

Os modelos matemáticos de predição de NUL, encontrados na literatura e estudados neste trabalho, consideram a maioria dos fatores conhecidos capazes de afetar as suas concentrações, incluindo consumo de nitrogênio, produção de leite e percentagem de proteína do leite. Além disso, um dos modelos é ajustado para efeitos do peso corporal. Tais 
modelos foram derivados de um primeiro modelo, proposto por Jonker et al. (1998) para predição de nitrogênio urinário $(\mathrm{NU})$, como segue na equação 1 :

$\mathrm{NU}=($ IN x 0,83) - NLeite -97,

sendo NU = excreção de nitrogênio urinário (g/dia); IN = ingestão de nitrogênio e NLeite = nitrogênio no leite (g/dia). A digestibilidade verdadeira da fonte de nitrogênio de 0,83 e do nitrogênio metabólico fecal de $97 \mathrm{~g} /$ dia foram assumidos por Jonker et al. (1998), ao estudarem, previamente, uma grande variedade de dietas. Esse modelo defende que o nitrogênio retido usado para crescimento e reservas é ínfimo para vacas adultas. O NRC (2001) assume que o nitrogênio metabólico fecal é função do peso corporal, mas a complexidade adicionada ao modelo não foi justificada, baseada no banco de dados usado por Jonker et al. (1998) ao desenvolvê-lo.

A partir dessa primeira equação, Jonker et al. (1998) propuseram o modelo 1 de predição de NUL (NU/12,54). Esse modelo foi obtido da regressão linear do NU contra NUL. O coeficiente da regressão indica que $1.254 \mathrm{~L} /$ dia de sangue são completamente filtrados, representando a taxa de remoção renal de uréia. Esse valor foi usado para calcular NUL a partir de NU, assumindo que NUL se equilibra com a uréia no sangue. $\mathrm{O}$ fato de a uréia se difundir para dentro e fora das células secretoras da glândula mamária, se equilibrando com a uréia no sangue, a torna proporcional a NUS. Essa relação permite a NUL ser um excelente preditor de NU e vice-versa. Expresso em termos de peso vivo, a taxa de remoção da uréia foi de $1,45 \mathrm{~mL} / \mathrm{min}$ por $\mathrm{kg}$ de $\mathrm{PV}$.

Como o nitrogênio urinário foi usado para predizer NUL, o cálculo dos três modelos estudados para sua predição exige informação sobre o consumo de nitrogênio, a produção de leite e a percentagem de proteína do leite. As concentrações preditas de NUL dependeram do modelo usado, sendo o modelo 1 exposto abaixo:

- modelo 1: NUL = NU/12,54 (Jonker et al., 1998); em que: $\mathrm{NUL}=$ nitrogênio uréico no leite $(\mathrm{mg} / \mathrm{dL})$ e $\mathrm{NU}=$ nitrogênio urinário (g/animal/dia).

1 RODRIGUES, P.H.M. (Faculdade de Medicina Veterinária da Universidade de São Paulo, Pirassununga/SP). Comunicação pessoal, 2002. 
Entretanto, Kohn et al. (2002) relataram que, em setembro de 1998, foi descoberto um defeito de "hardware" nos equipamentos de análise de NUL, que estavam sendo usados pelos laboratórios do DHIA (Dairy Herd Improvement Association) nos EUA, para analisar as amostras de curva-padrão. Quando esse defeito foi corrigido, os padrões de NUL mudaram, de modo que os laboratórios do DHIA passaram a relatar menores valores de NUL. Com a intenção de corrigir as concentrações de NUL anteriores e solucionar esse problema, Kohn et al (2002) apresentaram a seguinte equação:

$\mathrm{NUL}_{\text {novo }}=0,83 \times \mathrm{NUL}_{\text {velho }}-1,84$;

sendo $\mathrm{NUL}_{\text {novo }}=$ nitrogênio uréico no leite após a correção e $\mathrm{NUL}_{\text {velho }}=$ nitrogênio uréico no leite antes da correção.

Desse modo, a interpretação dos valores de NUL que haviam sido desenvolvidos, anteriormente, fica comprometida. Então, Kauffman \& St-Pierre (2001) desenvolveram os modelos 2 e 3 após a correção desse defeito, na tentativa de gerar resultados mais confiáveis e próximos aos da realidade. Além disso, o modelo 3 foi ajustado para o efeito de peso vivo. Dessa forma, as concentrações preditas de NUL dependeram do modelo usado e foram obtidas das seguintes equações:

- modelo 2: NUL = NU/17,6 (Kauffman \& St-Pierre, 2001);

- modelo 3: NUL = NU/(0,0259 x PV) (Kauffman \& StPierre, 2001);

sendo: $\mathrm{NUL}=$ nitrogênio uréico no leite $(\mathrm{mg} / \mathrm{dL}) ; \mathrm{NU}$ = nitrogênio urinário (g/animal/dia) e PV = peso vivo $(\mathrm{kg})$.

A proposta desses modelos é identificar quando NUL desvia de um valor esperado, podendo, assim, indicar um problema potencial de manejo. Ao usar os 3 diferentes modelos, NUL esperado é predito a partir de parâmetros da dieta e de produção e esses valores devem ser comparados com os valores observados de NUL. 


\section{MÉTODOS E TEMPO DE ARMAZENAMENTO DAS AMOSTRAS DE LEITE SOBRE NITROGÊNIO URÉICO, CONTAGEM DE CÉLULAS SOMÁTICAS E CONCENTRAÇÕES DE GORDURA, PROTEÍNA, LACTOSE E SÓLIDOS TOTAIS.}

\section{Resumo}

Este experimento foi conduzido para avaliar métodos e tempos de armazenamento das amostras nos resultados da análise do leite. Uma amostra de leite foi coletada em uma única vez, diretamente do tanque de expansão e colocada em 210 frascos. As amostras foram designadas aleatoriamente a um arranjo fatorial de tratamentos $4 \times 5+1$. Um dos fatores estudados foi método de armazenamento: 1) refrigerado (R) $\left(4^{\circ} \mathrm{C}\right)$; 2) congelado $(\mathrm{C})\left(-10^{\circ} \mathrm{C}\right)$; 3) armazenado em temperatura controlada (TC) (mantido em ambiente com ar condicionado - com temperatura variando de $22,1^{\circ} \mathrm{C}$ a $30,9^{\circ} \mathrm{C}$ ) e 4) armazenado em temperatura variável (TV) [temperatura ambiente (mínima de $22,1^{\circ} \mathrm{C}$ ) e aquecido a $40^{\circ} \mathrm{C}$ por $4 \mathrm{~h} /$ dia]. $\mathrm{O}$ outro fator foi tempo de armazenamento: 3, 6, 9, 12 e 15 dias entre amostragem e análise, mais dia 0, como controle. Foram analisadas as concentrações de gordura, proteína, lactose e sólidos totais (ST), a contagem de células somáticas (CCS) e o nitrogênio uréico no leite (NUL). Análise de variância foi realizada e, subseqüentemente, análises de regressão até efeito quadrático, assim como contrastes ortogonais. Os contrastes ortogonais estudados foram: controle (dia 0) contra todos os demais tratamentos; resfriado vs. não-resfriado $[(\mathrm{R}+\mathrm{C})$ vs. $(\mathrm{TC}+\mathrm{TV})], \mathrm{R} v s . \mathrm{C}$ e TC $v s . \mathrm{TV}$, dentro de cada tempo. A CCS foi transformada em logaritmo natural (LCCS). Os resultados mostraram interação entre os 
métodos e o tempo armazenamento para gordura, proteína, lactose, sólidos totais (\%) e LCCS, mas não para a concentração de NUL, que foi afetada, independentemente, pelos dois fatores. Não ocorreram diferenças significativas para as concentrações de gordura, no decorrer do tempo, para os armazenamentos $\mathrm{R}$ e $\mathrm{C}$, enquanto para os armazenamentos TC e TV, o percentual de gordura sofreu diminuições lineares significativas, em função do tempo, de 0,008 e 0,058 unidade percentual/dia, respectivamente. A concentração de proteína não sofreu efeitos da refrigeração, à medida que o tempo de armazenamento aumentava, mas apresentou falta de ajuste das equações linear e quadrática para os armazenamentos $\mathrm{C}$ e $\mathrm{TC}$ e um efeito quadrático para o armazenamento TV. A concentração de lactose apresentou falta de ajuste para as equações linear e quadrática, em função do tempo, para todos os métodos de armazenamento. Para os sólidos totais, houve decréscimo linear, em função do tempo de armazenamento, de 0,007, 0,016, 0,013 e 0,058 unidade percentual/dia para R, C, TC e TV, respectivamente. O LCCS apresentou declínios lineares significativos, à medida que o tempo aumentava, para todos os métodos de armazenamento $(0,01,0,006,0,07,0,23$ LCCS/dia para R, C, TC e TV, respectivamente). O NUL apresentou falta de ajuste para as equações lineares e quadráticas, em função do tempo, para todos os métodos de armazenamento. Desse modo, as melhores opções para o armazenamento das amostras de leite foram a refrigeração e o congelamento. Contudo, as amostras devem ser analisadas até 3 dias após sua coleta, para assegurar que os resultados da análise de leite, principalmente, da contagem de células somáticas e da gordura, sejam confiáveis. 


\section{METHODS AND TIME OF STORAGE OF MILK SAMPLES ON UREA NITROGEN, SOMATIC CELLS COUNT AND CONCENTRATIONS OF FAT, PROTEIN, LACTOSE AND TOTAL SOLIDS.}

\section{Summary}

A trial was conducted to evaluate methods and time of storage of milk samples on the results of milk analysis. Milk was collected from a bulk tank and poured into 210 vials. Samples were used in a completely randomized design with a 4x5+1 factorial arrangement of treatments. One factor was storage method: 1) refrigerated (R) $\left(4^{\circ} \mathrm{C}\right)$, 2) frozen $\left.(\mathrm{F})\left(-10^{\circ} \mathrm{C}\right), 3\right)$ stored at controlled temperature (CT) (kept in airconditioned room with temperature varying from $22.1^{\circ} \mathrm{C}$ to $30.9^{\circ} \mathrm{C}$ ) and 4 ) stored at variable temperature (VT) [room temperature (minimum temperature $=22,1^{\circ} \mathrm{C}$ ) and warmed up to $40^{\circ} \mathrm{C}$ for $4 \mathrm{~h} /$ day]. The other factor was storage time (time between sampling and analysis): 3, 6, 9, 12 and 15 days after sampling, plus day 0, used as control. Samples were analyzed for fat, protein, lactose and total solids (TS) concentration, somatic cells count (SCC) and milk urea nitrogen (MUN). Analysis of variance was done and, subsequently, regression analysis up to quadratic effect, as well as orthogonal contrasts. The orthogonal contrasts studied were: control (day 0) against all treatments; cold vs. not cold $[(\mathrm{R}+\mathrm{F}) v s .(\mathrm{CT}+\mathrm{VT})], \mathrm{R} v s . \mathrm{F}$ and $\mathrm{CT} v s$. VT, within each time. Somatic cells count was analyzed as natural log transformation (LSCC). Results showed interaction between storage method and time for fat, protein, lactose, TS and LSCC, but not for MUN, which was affected by storage method and time, independently. Fat was not affected by $\mathrm{R}$ and $\mathrm{F}$, but showed significant linear decreases, in function of time, for CT and VT and slopes were -0.008 and -0.058 percentile unit/day, respectively. Protein concentration was not affected by $\mathrm{R}$, as storage time increased, but showed lack of fit for linear and quadratic equations for F and CT and a quadratic effect for VT. Lactose had lack of fit for linear and quadratic effects for all storage methods, through time. There were significant linear effects through time for TS 
and slopes were, respectively, $-0.007,-0.016,-0.013,-0.058$ percentile unit/day for $\mathrm{R}, \mathrm{F}$, CT and VT. There were also linear decreases for LSCC of 0.01, 0.006, 0.069 and 0.226 LSCC/day for R, F, CT and VT, respectively, in function of time. Milk urea nitrogen showed lack of fit for linear and quadratic effects, through time, for all storage methods. Thus, the best options to store milk samples were refrigeration and freezing. Nevertheless, samples should be analyzed up to 3 days after collection to ensure that the results, mainly somatic cells count and fat concentration, are reliable.

\subsection{Introdução}

A demanda dos produtores brasileiros por análises de leite, seja de gordura e proteína ou da contagem de células somáticas, é crescente, em virtude da nova legislação brasileira de qualidade do leite e do pagamento diferenciado pela indústria. Dessa forma, a amostragem correta do leite e o procedimento adequado de conservação, até o momento de sua análise, são de extrema importância para garantir sua estabilidade física e química, de modo a gerar resultados confiáveis de seus componentes.

Marshall (1985) relatou que um erro de apenas 0,01 unidade percentual na gordura do leite teria um enorme impacto financeiro anual sobre os produtores. Entretanto, muitos fatores contribuem para a variação dos resultados obtidos com análises de gordura, proteína e contagem de células somáticas do leite. Entre eles, estariam o recipiente de transporte das amostras (Bertrand, 1996), o tipo de conservante (Bertrand, 1996; Monardes et al., 1996), o método de transporte e conservação, bem como o tempo entre a coleta das amostras e sua análise (Monardes et al., 1996).

Desse modo, as condições e o tempo de transporte e armazenamento das amostras de leite até sua análise no laboratório devem assegurar a conservação da composição do leite. A Federação Leiteira Internacional (International Dairy Federation, 1984) estipulou que as amostras para contagem de células somáticas deveriam ser analisadas com não mais de três dias após a coleta, presumidamente para prevenir problemas de deterioração do número de células durante o armazenamento. Todavia, foi 
provado que amostras quimicamente conservadas e refrigeradas podem ser armazenadas por mais de 10 dias e ainda proporcionar resultados acurados da análise do leite (Clarke et al., 1995).

Uma vez que as condições climáticas de calor intenso são frequientes no Brasil ( $35^{\circ} \mathrm{C}$ durante o verão), as amostras de leite sofrem o risco de coagulação. Assim, a refrigeração das amostras de leite, utilizada no programa americano de melhoria dos rebanhos leiteiros (DHI) ou em esquemas de pagamento de leite, tem sido recomendada para aumentar a confiabilidade das análises nos laboratórios automatizados e para reduzir a atividade microbiana e as reações químicas nesse alimento (Van de Voort et al., 1987). Também, as longas distâncias entre as fazendas leiteiras e os laboratórios têm despertado a possibilidade de se congelar as amostras de leite. Além disso, tem-se discutido sobre qual seria o tempo máximo de armazenamento até sua análise, sem alterar sua composição. Assim, surge a necessidade de se reavaliar os efeitos dos métodos de armazenamento e tempo decorrido desde a amostragem do leite até sua análise sobre as determinações da composição do leite.

Para responder essas questões, um experimento foi conduzido para avaliar se diferentes métodos de armazenamento e o tempo decorrido entre amostragem e análise afetariam os resultados da análise das concentrações de nitrogênio uréico no leite (NUL), gordura, proteína, lactose e sólidos totais e da contagem de células somáticas (CCS).

\subsection{Material e Métodos}

\subsubsection{Coleta de dados}

A amostra de leite foi coletada, em uma única vez, diretamente do tanque de expansão do rebanho leiteiro do Departamento de Zootecnia da Escola Superior de Agricultura "Luiz de Queiroz" da Universidade de São Paulo/Campus de Piracicaba, em março de 2001. Antes de realizar a coleta da amostra, procedeu-se à homogeneização do 
leite, mantendo-se o agitador do tanque ligado por, no mínimo, 5 minutos. Após esse procedimento, uma amostra (12,5 L) foi coletada diretamente da válvula de saída para um galão e, em seguida, transportada para o Laboratório de Fisiologia da Lactação da Clínica do Leite (ESALQ/USP).

No momento da chegada, o leite foi transferido de um balde para outro, procedimento repetido dez vezes consecutivas, até sua completa homogeneização e, logo a seguir, despejado em 210 recipientes plásticos $(60 \mathrm{~mL})$, cada um contendo duas pastilhas de bronopol (largo espectro) como conservante. Os recipientes foram preenchidos até a marca superior e, em seguida, tampados e tombados por, pelo menos, 5 vezes. Esse último procedimento foi repetido após 15 minutos, para assegurar que o leite foi bem homogeneizado com o conservante. Os recipientes foram alocados em caixas e designados a um arranjo fatorial de tratamentos $4 \times 5+1$.

Os fatores estudados foram: 4 diferentes métodos de armazenamento e 5 tempos entre amostragem e análise do leite, além de 1 tratamento controle. Os métodos de armazenamento foram: 1) refrigerado (R) (a $\left.4^{\circ} \mathrm{C}\right)$, 2) congelado (C) $\left.\left(-10^{\circ} \mathrm{C}\right), 3\right)$ armazenado à temperatura ambiente (TC) (mantido em ambiente com ar condicionado variando de $22,1^{\circ} \mathrm{C}$ a $30,9^{\circ} \mathrm{C}$ ) e 4 ) armazenado à temperatura variável (TV) (mantido à temperatura mínima de $22,1^{\circ} \mathrm{C}$ e aquecido a $40^{\circ} \mathrm{C}$ por $4 \mathrm{~h} /$ dia). Esse último procedimento incluiu a colocação das amostras em estufa $\left(40^{\circ} \mathrm{C}\right)$ por 4 horas, diariamente, das $10 \mathrm{~h}$ até as $14 \mathrm{~h}$. No momento da análise, a temperatura dessas amostras era de $35^{\circ} \mathrm{C}$, em média. A razão desse tratamento foi para simular uma condição em que as amostras tivessem sido deixadas dentro de um veículo sob o sol, em um país tipicamente tropical, como é o Brasil. Essa é uma situação muito comum onde o experimento foi conduzido, seja causada pelo controlador de leite ou pela transportadora.

$\mathrm{O}$ outro fator estudado foi o tempo de armazenamento (tempo decorrido entre a amostragem do leite e sua análise), sendo 3, 6, 9, 12 e 15 dias após a coleta. No dia 0 (dia da amostragem), foram analisadas 10 amostras como tratamento controle, enquanto nos dias 3, 6, 9, 12, 15 após a amostragem, 10 amostras foram analisadas para cada método de armazenamento. Entretanto, por um equívoco no momento da análise, para o nitrogênio uréico no leite (NUL), em vez de 10, foram analisadas apenas 2 
amostras do armazenamento com temperatura variável (TV) no dia 15. Antes da análise, as amostras foram aquecidas a $60^{\circ} \mathrm{C}$ por 15 minutos, utilizando-se banho-maria. Mas, previamente a esse procedimento, as amostras congeladas foram deixadas à temperatura ambiente por 30 minutos e, em seguida, descongeladas em banho-maria.

As concentrações de gordura, proteína, lactose e sólidos totais foram determinadas por absorção infravermelha, utilizando-se o equipamento Bentley $2000^{\circledR}$ (Bentley Instruments, 1995a); a contagem de células somáticas (x $10^{3}$ células $/ \mathrm{mL}$ ), por citometria de fluxo, com o equipamento Somacount $300^{\circledR}$ (Bentley Instruments, 1995b) e o nitrogênio uréico no leite $(\mathrm{mg} / \mathrm{dL})$, por método enzimático e espectrofotométrico de trans-reflectância, por meio do equipamento ChemSpeck $150^{\circledR}$ (Bentley Instruments, 1998).

\subsubsection{Análise estatística}

Os dados foram analisados usando o procedimento PROC GLM do SAS (1999). A análise de variância foi realizada considerando-se o modelo para esse delineamento (consistindo de métodos de armazenamento, tempo entre amostragem e análise do leite e interação entre os fatores principais). Subseqüentemente, foi testada a existência de efeito do tempo dentro de cada método de armazenamento, realizando-se, também, análises de regressão até o efeito quadrático.

Para maior detalhamento da análise, contrastes ortogonais foram realizados. O primeiro deles foi "controle vs. demais" (controle versus todos os outros tratamentos). Posteriormente, para estudar a interação entre os fatores principais, outros contrastes ortogonais foram realizados dentro de cada tempo de armazenamento, sendo: "resfriado vs. não-resfriado" $[(\mathrm{R}+\mathrm{C}) v s$. $(\mathrm{TC}+\mathrm{TV})]$; "refrigerado $v s$. congelado" ( $\mathrm{R} v s$. C); "temperatura controlada $v s$. temperatura variável" (TC vs. TV), totalizando assim 15 contrastes. A contagem de células somáticas (CCS) (x $10^{3}$ células $/ \mathrm{mL}$ ) foi transformada em logaritmo natural (LCCS), pois não possui distribuição normal (Godden et al., 2001b). Para todas as análises, utilizou-se nível de significância de 5\%. 


\subsection{Resultados e Discussão}

A composição média do leite amostrado para análise (dia 0) foi: 3,31\% de gordura, 2,95\% de proteína, 4,58\% de lactose e 11,53\% de sólidos totais. A contagem média de células somáticas foi de 546,9 (amplitude de 524 a 585 x $10^{3}$ células $/ \mathrm{mL}$ ) e a concentração média de nitrogênio uréico no leite (NUL) foi de 5,66 mg/dL.

As médias da concentração de gordura, proteína, lactose e sólidos totais, o logaritmo natural da contagem de células somáticas (LCCS) e o nitrogênio uréico no leite estão apresentados na Tabela 1. 
Tabela 1. Médias de gordura, proteína, lactose e sólidos totais do leite, logaritmo natural da contagem de células somáticas e nitrogênio uréico no leite para os métodos de armazenamento, em função do tempo decorrido entre amostragem e análise

\begin{tabular}{|c|c|c|c|c|c|c|}
\hline \multirow[t]{2}{*}{ Métodos de armazenamento } & \multicolumn{6}{|c|}{ Tempos de armazenamento (dias) } \\
\hline & $\mathbf{0}$ & 3 & 6 & 9 & 12 & 15 \\
\hline & \multicolumn{6}{|c|}{ Gordura (\%) } \\
\hline Refrigerado & \multirow{4}{*}{3,31} & 3,29 & 3,26 & 3,24 & 3,29 & 3,26 \\
\hline Congelado & & 3,23 & 3,29 & 3,21 & 3,20 & 3,25 \\
\hline Temperatura controlada & & 3,24 & 3,25 & 3,21 & 3,18 & 3,19 \\
\hline Temperatura variável & & 3,14 & 3,06 & 2,88 & 2,61 & 2,46 \\
\hline & \multicolumn{6}{|c|}{ Proteína (\%) } \\
\hline Refrigerado & \multirow{4}{*}{2,95} & 2,95 & 2,94 & 2,93 & 2,94 & 2,94 \\
\hline Congelado & & 2,93 & 2,94 & 2,89 & 2,91 & 2,89 \\
\hline Temperatura controlada & & 2,94 & 2,94 & 2,90 & 2,90 & 2,96 \\
\hline Temperatura variável & & 2,93 & 2,93 & 2,92 & 2,93 & 2,95 \\
\hline & \multicolumn{6}{|c|}{ Lactose (\%) } \\
\hline Refrigerado & \multirow{4}{*}{4,58} & 4,61 & 4,57 & 4,56 & 4,58 & 4,53 \\
\hline Congelado & & 4,62 & 4,53 & 4,56 & 4,61 & 4,46 \\
\hline Temperatura controlada & & 4,62 & 4,56 & 4,56 & 4,60 & 4,52 \\
\hline Temperatura variável & & 4,63 & 4,59 & 4,60 & 4,60 & 4,59 \\
\hline & \multicolumn{6}{|c|}{ Sólidos totais (\%) } \\
\hline Refrigerado & \multirow{4}{*}{11,53} & 11,55 & 11,46 & 11,42 & 11,50 & 11,42 \\
\hline Congelado & & 11,47 & 11,44 & 11,34 & 11,41 & 11,25 \\
\hline Temperatura controlada & & 11,50 & 11,45 & 11,36 & 11,37 & 11,36 \\
\hline \multirow[t]{2}{*}{ Temperatura variável } & & 11,40 & 11,27 & 11,09 & 10,83 & 10,69 \\
\hline & \multicolumn{6}{|c|}{ Logaritmo natural da contagem de células somáticas } \\
\hline Refrigerado & \multirow{4}{*}{6,30} & 6,22 & 6,25 & 6,20 & 6,22 & 6,11 \\
\hline Congelado & & 6,21 & 6,29 & 6,24 & 6,20 & 6,19 \\
\hline Temperatura controlada & & 6,08 & 5,98 & 5,84 & 5,50 & 5,22 \\
\hline \multirow[t]{2}{*}{ Temperatura variável } & & 5,79 & 5,41 & 4,47 & 3,43 & 3,17 \\
\hline & \multicolumn{6}{|c|}{ Nitrogênio uréico no leite (mg/dL) } \\
\hline Refrigerado & \multirow{4}{*}{5,66} & 5,99 & 5,77 & 5,96 & 5,88 & 6,21 \\
\hline Congelado & & 6,38 & 5,89 & 5,83 & 5,93 & 6,34 \\
\hline Temperatura controlada & & 5,97 & 5,82 & 5,86 & 6,07 & 6,26 \\
\hline Temperatura variável & & 6,27 & 5,86 & 6,00 & 6,08 & $6,50^{*}$ \\
\hline
\end{tabular}

Pela Tabela 2, nota-se que os tratamentos influenciaram todas as variáveis estudadas, excluindo-se a lactose, uma vez que os resultados das análises do dia 0 (controle) diferiram $(\mathrm{P}<0,01)$ dos demais tratamentos. Observa-se também interação $(\mathrm{P}<0,01)$ entre os métodos e os tempos de armazenamento para gordura, proteína, 
lactose, sólidos totais (\%) e contagem de células somáticas (LCCS), mas não para a concentração de nitrogênio uréico no leite, sendo essa afetada, independentemente, pelos dois fatores principais (Tabela 2).

Tabela 2. Análise de variância para gordura, proteína, lactose e sólidos totais do leite (\%), contagem de células somáticas (LCCS) e nitrogênio uréico no leite $(\mathrm{mg} / \mathrm{dL})$

\begin{tabular}{lccccccc}
\hline Causas de variação & $\mathbf{G L}^{\mathbf{7}}$ & \multicolumn{6}{c}{$\mathbf{Q M}^{\mathbf{6}}$} \\
& & Gordura & Proteína & Lactose & ST $^{\mathbf{8}}$ & LCCS $^{\mathbf{9}}$ & NUL $^{\mathbf{1 0}}$ \\
\hline Controle $v \boldsymbol{s}$. demais $^{1}$ & 1 & $0,29^{* *}$ & $0,004^{* *}$ & 0,0003 & $0,401^{* *}$ & $4,05^{* *}$ & $1,417^{* *}$ \\
Armazenamento $^{2}$ & 3 & $2,11^{* *}$ & $0,007^{* * *}$ & $0,02^{* *}$ & $1,721^{* *}$ & $34,48^{* *}$ & $0,249^{*}$ \\
Tempo (dias) $^{3}$ & 4 & $0,28^{* *}$ & $0,008^{* *}$ & $0,049^{* *}$ & $0,546^{* *}$ & $6,16^{* *}$ & $1,132^{* *}$ \\
Armazenamento x tempo $^{4}$ & 12 & $0,19^{* *}$ & $0,003^{* *}$ & $0,005^{* *}$ & $0,161^{* *}$ & $2,88^{* *}$ & 0,104 \\
Resíduo & $189^{*}$ & 0,017 & 0,0003 & 0,0002 & 0,014 & 0,015 & 0,069 \\
Total & $209^{*}$ & & & & & & \\
CV $(\%)^{5}$ & & 4,08 & 0,54 & 0,34 & 1,03 & 2,14 & 4,37 \\
\hline
\end{tabular}

1 contraste entre controle $v s$. demais tratamentos; ${ }^{2}$ efeito do método de armazenamento; ${ }^{3}$ efeito do tempo de armazenamento; ${ }^{4}$ interação entre método e temp o de armazenamento; ${ }^{5}$ coeficiente de variação; ${ }^{6}$ quadrado médio; ${ }^{7}$ graus de liberdade; ${ }^{8}$ sólidos totais; ${ }^{9}$ logaritmo natural da contagem de células somáticas; ${ }^{10}$ nitrogênio uréico no leite; $* \mathrm{P}<0,05 ; * * \mathrm{P}<0,01 ;{ }^{*}$ o número de graus de liberdade do resíduo para a concentração de nitrogênio uréico no leite é de 181, pois apenas 2 amostras foram analisadas para o armazenamento com temperatura variável (TV) no dia $15 ;^{*}$ o número de GL total para NUL é de 201 , pelo mesmo motivo citado anteriormente.

\subsubsection{Gordura do leite}

A concentração de gordura do leite sofreu influência dos tratamentos, que, em média, diferiram do controle (dia 0), como pode ser observado pela significância $(\mathrm{P}<0,01)$ do contraste "controle vs. demais" (Tabela 2). Porém, ao longo do tempo, não foi afetada pelo armazenamento refrigerado $(\mathrm{R})$ e congelado $(\mathrm{C})$. Entretanto, sofreu diminuições lineares significativas (Tabela 3), ao longo do tempo, para os armazenamentos com temperatura controlada $(\mathrm{TC})(\mathrm{P}<0,05)$ e temperatura variável (TV) $(\mathrm{P}<0,01)$. As inclinações das retas indicam que as amostras mantidas em TC tiveram um declínio de 0,008 unidade percentual de gordura do leite por dia, enquanto que as amostras mantidas em TV apresentaram um declínio bem maior, de 0,058 unidade percentual de gordura por dia. 
Tabela 3. Análise do efeito do tempo (dias decorridos entre amostragem e análise) dentro de cada método de armazenamento (resfriado, congelado, temperatura controlada e temperatura variável)

\begin{tabular}{|c|c|c|c|c|c|c|c|}
\hline \multirow[t]{2}{*}{$\mathbf{C V}^{1}$} & \multirow[t]{2}{*}{$\mathbf{G L}^{10}$} & \multicolumn{6}{|c|}{ Quadrado médio } \\
\hline & & Gordura & Proteína & Lactose & $\mathrm{ST}^{11}$ & $\mathrm{LCCS}^{12}$ & $\mathbf{N U L}^{13}$ \\
\hline \multicolumn{8}{|l|}{ Refrigerado $^{2}$} \\
\hline Tempo $^{3}$ & 5 & 0,007 & 0,0006 & $0,006^{* *}$ & $0,031 *$ & $0,040 *$ & $0,364 * *$ \\
\hline Linear $^{4}$ & 1 & 0,012 & 0,0005 & $0,016^{* *}$ & $0,084 *$ & $0,143 * *$ & $0,970 * *$ \\
\hline Quadrático 5 & 1 & 0,008 & 0,0009 & $0,003^{* *}$ & 0,003 & 0,004 & 0,033 \\
\hline F.A. $^{6}$ & 3 & 0,005 & 0,0005 & $0,004 * *$ & 0,022 & 0,018 & $0,273^{* *}$ \\
\hline \multicolumn{8}{|l|}{ Congelado $^{7}$} \\
\hline Tempo & 5 & 0,019 & $0,006^{* *}$ & $0,033 * *$ & $0,098 * *$ & 0,024 & $0,853 * *$ \\
\hline Linear & 1 & 0,033 & $0,0239 * *$ & $0,052^{* *}$ & $0,403 * *$ & $0,058 *$ & $0,580 * *$ \\
\hline Quadrático & 1 & 0,016 & 0,00003 & $0,016^{* *}$ & 0,0004 & 0,0007 & 0,077 \\
\hline F.A. & 3 & 0,015 & $0,0027 * *$ & $0,033 * *$ & 0,029 & 0,021 & $1,202 * *$ \\
\hline \multicolumn{8}{|c|}{$\mathbf{T}^{0} \mathrm{C}$ controlada ${ }^{8}$} \\
\hline Tempo & 5 & 0,024 & $0,008^{* *}$ & $0,012^{* *}$ & $0,062 * *$ & $1,561^{* *}$ & $0,450 * *$ \\
\hline Linear & 1 & $0,099 *$ & $0,0012 *$ & $0,017 * *$ & $0,271 * *$ & $7,516^{* *}$ & $1,607 * *$ \\
\hline Quadrático & 1 & 0,006 & $0,0149 * *$ & $0,003 * *$ & 0,018 & 0,176 & 0,092 \\
\hline F.A. & 3 & 0,004 & $0,0077 * *$ & $0,013^{* *}$ & 0,007 & 0,038 & $0,184 *$ \\
\hline
\end{tabular}

\begin{tabular}{llllllll}
$\begin{array}{l}\text { T}^{\mathbf{0}} \text { C variável } \\
\text { Tempo }\end{array}$ & 5 & $1,063^{* *}$ & $0,002^{* *}$ & $0,003^{* *}$ & $1,087^{* *}$ & $16,505^{* *}$ & $0,585^{* *}$ \\
$\quad$ Linear & 1 & $5,203^{* *}$ & 0,00002 & 0,00005 & $5,363^{* *}$ & $80,216^{* *}$ & $0,843^{* *}$ \\
Quadrático & 1 & 0,056 & $0,0069^{* *}$ & $0,001^{*}$ & 0,036 & 0,235 & 0,053 \\
F.A. & 3 & 0,019 & 0,0003 & $0,004^{* *}$ & 0,011 & 0,692 & $0,676^{* *}$ \\
\hline
\end{tabular}

'causas de variação; ${ }^{2}$ armazenamento: refrigerado; ${ }^{3}$ tempo de armazenamento; ${ }^{4}$ regressão linear;

${ }^{5}$ regressão quadrática; ${ }^{6}$ falta de ajuste; ${ }^{7}$ armazenamento: congelado; ${ }^{8}$ armazenamento: temperatura controlada; ${ }^{9}$ armazenamento: temperatura variável; ${ }^{10}$ graus de liberdade; ${ }^{11}$ sólidos totais (\%); ${ }^{12}$ logaritmo natural da contagem de células somáticas; ${ }^{13}$ nitrogênio uréico no leite $(\mathrm{mg} / \mathrm{dL}) ; * \mathrm{P}<0,05 ; * * \mathrm{P}<0,01$.

O contraste "resfriado $v s$. não-resfriado" $[(\mathrm{R}+\mathrm{C})$ vs. $(\mathrm{TC}+\mathrm{TV})]$ foi significativo $(\mathrm{P}<0,01)$ nos dias 6 (3,28 vs. 3,16\%), 9 (3,23 vs. 3,05\%), 12 (3,25 vs. $2,90 \%)$ e 15 (3,26 vs. 2,83\%) (Tabela 4). Esses resultados indicam que a gordura das amostras que sofreram resfriamento diferiu das que não sofreram (que permaneceram em temperatura ambiente) a partir do $6^{\circ}$ dia após a amostragem até o $15^{\circ}$ dia. As amostras não-resfriadas apresentaram menor concentração de gordura, em relação às resfriadas, sendo que essas diferenças foram se acentuando, à medida que o tempo de armazenamento aumentava. 
Tabela 4. Estimativas dos contrastes para comparação dos métodos de armazenamento (resfriado, congelado, temperatura controlada e temperatura variável) dentro de cada tempo (dias)

\begin{tabular}{|c|c|c|c|c|c|c|}
\hline \multirow[t]{2}{*}{ Tempo $^{1}$} & \multicolumn{6}{|c|}{$\begin{array}{l}\text { Estimativa dos contrastes } \\
\end{array}$} \\
\hline & Gordura & Proteína & Lactose & $\mathbf{T S}^{5}$ & $\mathrm{LCCS}^{6}$ & $\mathbf{N U L}^{7}$ \\
\hline \multicolumn{7}{|l|}{3 dias } \\
\hline$[(\mathrm{R}+\mathrm{C}) v s .(\mathrm{TC}+\mathrm{TV})]^{2}$ & 0,137 & 0,007 & $-0,027 * *$ & 0,109 & $0,555^{* *}$ & 0,127 \\
\hline $\mathrm{R} v s . \mathrm{C}^{3}$ & 0,060 & $0,019 * *$ & $-0,007$ & 0,074 & 0,009 & $-0,387 * *$ \\
\hline $\mathrm{TC} v s . \mathrm{TV}^{4}$ & 0,099 & 0,004 & $-0,008$ & 0,101 & $0,289^{* *}$ & $-0,300 *$ \\
\hline \multicolumn{7}{|l|}{6 dias } \\
\hline$[(\mathrm{R}+\mathrm{C}) v s .(\mathrm{TC}+\mathrm{TV})]$ & $0,237 * *$ & 0,009 & $-0,049 * *$ & $0,186^{*}$ & $1,141 * *$ & $-0,017$ \\
\hline $\mathrm{R} v s . \mathrm{C}$ & $-0,024$ & 0,001 & $0,043 * *$ & 0,025 & $-0,045$ & $-0,121$ \\
\hline TC vs. TV & $0,193 * *$ & 0,014 & $-0,032 * *$ & $0,177^{* *}$ & $0,568 * *$ & $-0,046$ \\
\hline \multicolumn{7}{|l|}{9 dias } \\
\hline$[(\mathrm{R}+\mathrm{C}) v s .(\mathrm{TC}+\mathrm{TV})]$ & $0,353 * *$ & 0,004 & $-0,035 * *$ & $0,319 * *$ & $2,138 * *$ & $-0,068$ \\
\hline $\mathrm{R} v s . \mathrm{C}$ & 0,031 & $0,036 * *$ & 0,007 & 0,082 & $-0,040$ & 0,131 \\
\hline TC vs. TV & $0,330 * *$ & $-0,020 * *$ & $-0,036 * *$ & $0,271^{* *}$ & $1,373 * *$ & $-0,141$ \\
\hline \multicolumn{7}{|l|}{12 dias } \\
\hline$[(\mathrm{R}+\mathrm{C}) v s .(\mathrm{TC}+\mathrm{TV})]$ & $0,703 * *$ & 0,017 & $-0,013$ & $0,714 * *$ & $3,485^{* *}$ & $-0,334 *$ \\
\hline $\mathrm{R} v s . \mathrm{C}$ & 0,087 & $0,033^{* *}$ & $-0,025 * *$ & 0,089 & 0,223 & $-0,049$ \\
\hline TC vs. TV & $0,566^{* *}$ & $-0,038 * *$ & 0,000 & $0,533^{* *}$ & $2,065^{* *}$ & $-0,019$ \\
\hline \multicolumn{7}{|l|}{15 dias } \\
\hline$[(\mathrm{R}+\mathrm{C}) v s .(\mathrm{TC}+\mathrm{TV})]$ & $0,857 * *$ & $-0,083 * *$ & $-0,127 * *$ & $0,622 * *$ & $3,905^{* *}$ & $-0,217$ \\
\hline $\mathrm{R} v s . \mathrm{C}$ & 0,012 & $0,054 * *$ & $0,072 * *$ & $0,162 * *$ & $-0,082$ & $-0,135$ \\
\hline TC vs. TV & $0,733 * *$ & 0,011 & $-0,069 * *$ & $0,672 * *$ & $2,062 * *$ & $-0,236$ \\
\hline
\end{tabular}

${ }^{1}$ tempo de armazenamento (dias); ${ }^{2}$ contraste resfriado $v s$. não-resfriado [(R + C) $\left.v s .(\mathrm{TC}+\mathrm{TV})\right]{ }^{3}{ }^{3}$ contraste entre armazenamento refrigerado vs. congelado ( $\mathrm{R} v s . \mathrm{C}$ ); ${ }^{4}$ contraste entre armazenamento com temperatura controlada $v s$. temperatura variável (TC vs. TV); ${ }^{5}$ sólidos totais $(\%) ;{ }^{6}$ logaritmo natural da contagem de células somáticas; ${ }^{7}$ nitrogênio uréico no leite (mg/dL); $* \mathrm{P}<0,05 ; * * \mathrm{P}<0,01$.

Os resultados encontrados concordam com os obtidos por Kroger (1971), que reportou depressões na gordura do leite de 0,03,0,13 e 0,18 unidade percentual, respectivamente, após 3, 5 e 7 dias de armazenamento, sem resfriamento. O autor acredita que essa depressão seja devida a mudanças na estrutura física do glóbulo de gordura com o envelhecimento das amostras de leite. Contudo, Chavez et al. (1991) relataram que a gordura do leite não variou quando as amostras do leite foram refrigeradas por vários dias, mas diminuiu quando mantidas à temperatura ambiente ou em temperaturas elevadas. Ng-Kwai-Hang et al. (1988) também reportaram menor percentual de gordura em amostras transportadas em condições de temperatura variável, aos 3 dias após a coleta. 
O contraste "temperatura controlada $v s$. temperatura variável" (CT vs. VT) foi significativo $(\mathrm{P}<0,01)$ nos dias 6 (3,25 vs. 3,06\%), 9 (3,21 vs. 2,88\%), 12 (3,18 vs. $2,61 \%)$ e 15 (3,19 vs. 2,46\%) (Tabela 4). Observa-se que as amostras mantidas em ambiente com temperatura variável, ou seja, que sofreram aquecimento, apresentaram percentuais de gordura cada vez menores, à medida que o tempo de armazenamento aumentava, em relação às amostras que foram mantidas em ambiente controlado (com uso de ar condicionado).

A depressão na gordura do leite, com o aumento do tempo entre a coleta e a análise da amostra, está de acordo com os resultados de outros pesquisadores (Kroger, 1971 e Van de Voort et al., 1987) e tem sido atribuída à lipólise (Van de Voort et al., 1987 e Ng-Kwai-Hang et al., 1988), devido à atividade das lipases durante o armazenamento (Andersson, 1980). Celestino et al. (1996) relataram atividade de lipases mesmo em amostras refrigeradas por 2 dias, resultando em alta concentração de ácidos graxos livres durante o armazenamento. As lipases liberam os ácidos graxos dos triglicerídios, levando à redução nas ligações éster, que são, geralmente, medidas pelos instrumentos de leitura por infravermelho (Van de Voort et al., 1987).

Monardes et al. (1996) observaram que amostras que sofreram refrigeração completa (desde a amostragem, durante o transporte e até momento de sua análise), quando comparadas àquelas que sofreram refrigeração somente após a chegada ao laboratório, apresentaram maior concentração de gordura. Sugeriram, então, que a refrigeração das amostras (desde sua amostragem até sua análise) parece ser um método ideal para evitar reduções significativas nos valores de gordura do leite.

De acordo com Kroger (1985), o método ideal de conservação das amostras de leite por vários dias antes da análise é a refrigeração, o mais próximo possível do ponto de congelamento, sem congelá-las. Isso previne o crescimento de bactérias e todas as mudanças físicas e químicas que o seguem. A formação de cristais de gelo, geralmente, rompe as estruturas físicas do leite, dificultando a retirada de subamostras representativas (alíquotas).

Entretanto, o contraste "resfriado vs. congelado" não foi significativo em nenhum dos tempos, sugerindo que não há diferenças entre a concentração de gordura 
do leite das amostras resfriadas ou congeladas (Tabela 4). Outros estudos mostraram que o congelamento fez declinar a concentração de gordura do leite (Lee et al., 1986; Timms et al., 1987).

Os efeitos dos métodos de armazenamento, em função do tempo, sobre a gordura do leite (\%) estão apresentados na Figura 1.

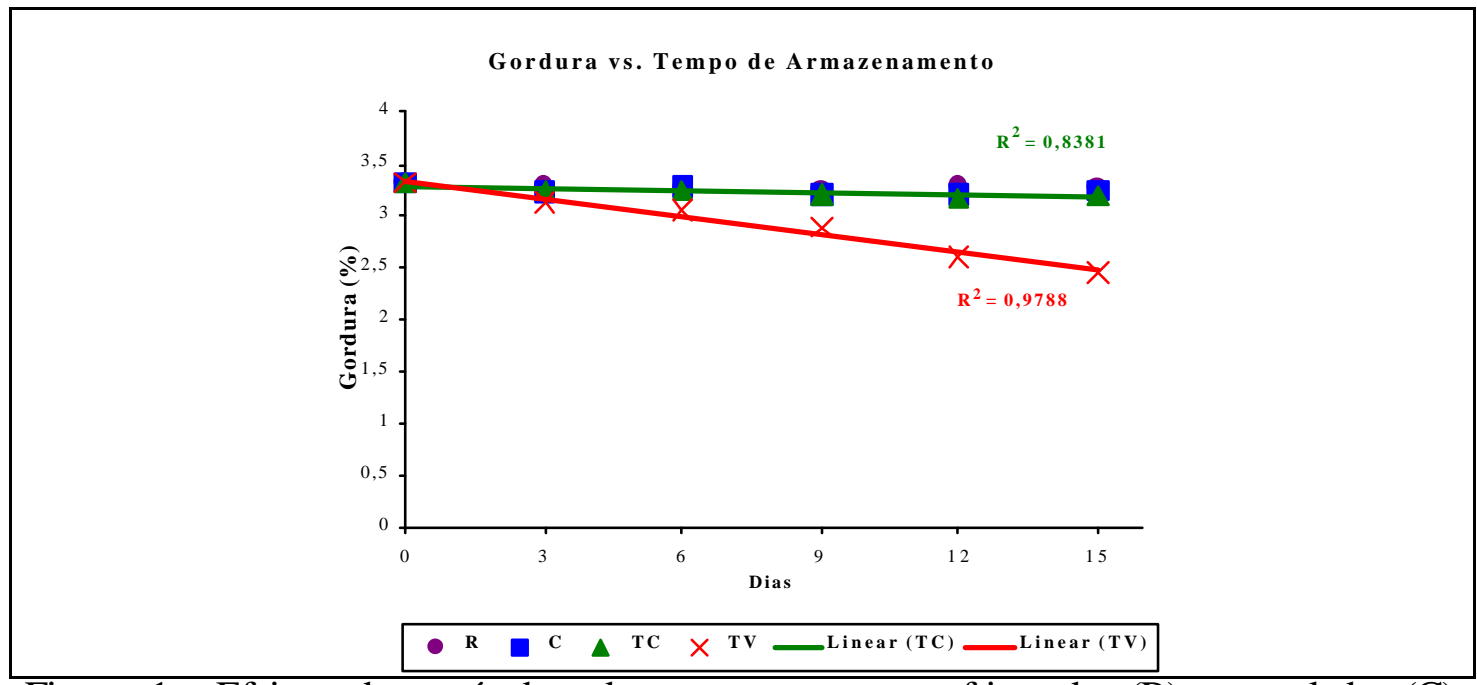

Figura 1- Efeitos dos métodos de armazenamento refrigerado (R), congelado (C), temperatura controlada (TC) e temperatura variável (TV), em função do tempo, sobre a concentração de gordura do leite

\subsubsection{Proteína do leite}

Observa-se que a concentração de proteína do leite foi influenciada pelos tratamentos, como mostra o contraste "controle vs. demais" $(\mathrm{P}<0,01)$, diferindo, em média, do controle (dia 0) (Tabela 2).

A proteína não foi afetada pelo tempo de armazenamento das amostras quando sofreram refrigeração (Tabela 3). Mas apresentou falta de ajuste para as equações linear e quadrática $(\mathrm{P}<0,01)$, para o armazenamento congelado (C) e com temperatura controlada $(\mathrm{TC})$, e efeito quadrático $(\mathrm{P}<0,01)$ para o armazenamento com temperatura variável (TV) (Tabela 3). O contraste "resfriado vs. não-resfriado" $[(\mathrm{R}+\mathrm{C})$ $v s .(\mathrm{TC}+\mathrm{TV})]$ foi significativo $(\mathrm{P}<0,01)$ apenas no dia $15(2,92$ vs. 2,96\%) (Tabela 4). 
Ng-Kwai-Hang \& Hayes (1982) relataram que o conteúdo de proteína de amostras mantidas em temperatura ambiente sofreu aumento de 3,14 para 3,24\% entre os dias 1 e 4, diminuição de 3,24 para 3,04\% entre os dias 4 e 7 e outro aumento de 3,04 para 3,18\% entre os dias 7 e 10, apresentando efeito cúbico. Entretanto, Chavez et al. (1991) reportaram que a proteína do leite variou quando as amostras do leite foram armazenadas à temperatura ambiente ou em temperaturas elevadas, mas não variou quando sofreram refrigeração.

Para essa variável, o contraste "refrigerado vs. congelado" ( $\mathrm{R} v s$. C) foi significativo $(\mathrm{P}<0,01)$ em quase todos os tempos, excetuando-se o $6^{\circ}$ dia (Tabela 4). Também, o contraste "temperatura controlada vs. temperatura variável" (TC vs. TV) apresentou significância $(\mathrm{P}<0,01)$ nos dias 9 (2,90 vs. 2,92\%) e $12(2,90$ vs. 2,93\%) (Tabela 4). De acordo com Monardes et al. (1996), a proteína do leite não sofreu efeito do tempo, nem interação entre o tipo e o tempo de armazenamento.

\subsubsection{Lactose}

A concentração de lactose, em média, não sofreu influência dos tratamentos, uma vez que o contraste "controle $v s$. demais" não foi significativo (Tabela 2). Entretanto, essa variável apresentou falta de ajuste para as equações linear e quadrática $(\mathrm{P}<0,01)$, no decorrer do tempo, para todos os métodos de armazenamento (Tabela 3). O contraste "resfriado vs. não-resfriado" $[(\mathrm{R}+\mathrm{C}) v s .(\mathrm{TC}+\mathrm{TV})]$ foi significativo $(\mathrm{P}<0,01)$ para todos os tempos, excetuando-se o $12^{\circ}$ dia: dia $3(4,62$ vs. 4,63\%), dia 6 (4,55 vs. 4,58\%), dia 9 (4,56 vs. 4,58\%) e dia 15 (4,50 vs. 4,56\%) (Tabela 4).

Da mesma forma, o contraste "refrigerado vs. congelado" ( $\mathrm{R} v s . \mathrm{C})$ foi significativo $(\mathrm{P}<0,01)$ nos dias $6(4,57$ vs. 4,53\%), 12 (4,58 vs. 4,61\%) e $15(4,53$ vs. 4,46\%) (Tabela 4). O contraste "temperatura controlada $v s$. temperatura variável" (TC vs. TV) foi significativo $(\mathrm{P}<0,01)$ nos dias 6 (4,56 vs. 4,59\%), 9 (4,56 vs. 4,60\%) e 15 (4,52 vs. 4,59\%) (Tabela 4). 
Não foram encontrados na literatura trabalhos que avaliassem a influência do armazenamento das amostras de leite sobre a concentração de lactose, dificultando, assim, a discussão e a comparação dessa variável.

\subsubsection{Sólidos totais do leite}

Nota-se, no contraste "controle vs. demais" $(\mathrm{P}<0,01)$, que os sólidos totais da amostra controle diferiram dos demais tratamentos, revelando que houve influência dos tratamentos sobre essa variável (Tabela 2).

Para os sólidos totais do leite, houve efeito linear significativo, em função do tempo, para o armazenamento refrigerado $(\mathrm{R})(\mathrm{P}<0,05)$, congelado $(\mathrm{C})$, temperatura controlada (TC) e temperatura variável $(\mathrm{P}<0,01)$ (Tabela 3), com inclinações das retas ("slopes") de, respectivamente, -0,007, -0,016, -0,013 e -0,058 unidade percentual/dia. Tais resultados indicam que os armazenamentos R, C, TC e TV apresentaram declínios de 0,007, 0,016, 0,013 e 0,058 unidade percentual de sólidos totais por dia, mostrando que as amostras mantidas em temperatura variável, ou seja, sofrendo aquecimento, apresentaram a maior queda na percentagem de sólidos totais.

Essa maior variação no armazenamento com temperatura variável fez com que os sólidos totais diminuíssem, aproximadamente, 0,84 unidade percentual entre os dias 0 e 15 (11,53\% no dia 0 e 10,69\% no dia 15$)$, o que equivale a uma diminuição de 7,3\%. Entretanto, pode-se sugerir que a queda nos sólidos totais do leite, em função do tempo e, principalmente, para as amostras armazenadas sem resfriamento, foi devida à queda na gordura do leite, reportada anteriormente.

O contraste "resfriado vs. não-resfriado" $[(\mathrm{R}+\mathrm{C}) v s$. $(\mathrm{TC}+\mathrm{TV})]$ se apresentou significativo nos dias 6 (11,45 vs. 11,36\%) ( $\mathrm{P}<0,05), 9$ (11,38 vs. 11,23\%), $12(11,46$ vs. $11,10 \%)$ e $15(11,34$ vs. $11,03 \%)(\mathrm{P}<0,01)$ (Tabela 4). Nota-se que as amostras mantidas sem resfriamento apresentaram menores valores de sólidos totais, em relação às resfriadas, e que as diferenças foram se acentuando, à medida que o tempo de armazenamento aumentava. Porém, o contraste "refrigerado vs. congelado" (R vs. C) foi 
apenas significativo $(\mathrm{P}<0,01)$ no dia 15 (11,42 vs. 11,25\%) (Tabela 4), ou seja, as concentrações de sólidos totais só diferiram entre as amostras refrigeradas e congeladas após 15 dias da amostragem do leite.

Por sua vez, o contraste "temperatura controlada $v s$. temperatura variável" (TC vs. TV) foi significativo $(\mathrm{P}<0,01)$ no dia $6(11,45$ vs. 11,27\%), dia 9 (11,36 vs. 11,09\%), dia 12 (11,37 vs. 10,83\%) e dia 15 (11,36 vs. 10,69\%) (Tabela 4). Percebe-se, à medida que o tempo de armazenamento avança, um aumento na diferença entre os sólidos totais das amostras mantidas em temperatura controlada e variável, podendo-se sugerir que seja devido à queda na gordura do leite, como discutida anteriormente.

A discussão e comparação da influência do armazenamento das amostras de leite sobre a concentração de sólidos totais também se tornam difíceis pela ausência de trabalhos na literatura.

Os efeitos dos métodos de armazenamento, em função do tempo, sobre os sólidos totais do leite estão apresentados na Figura 2.

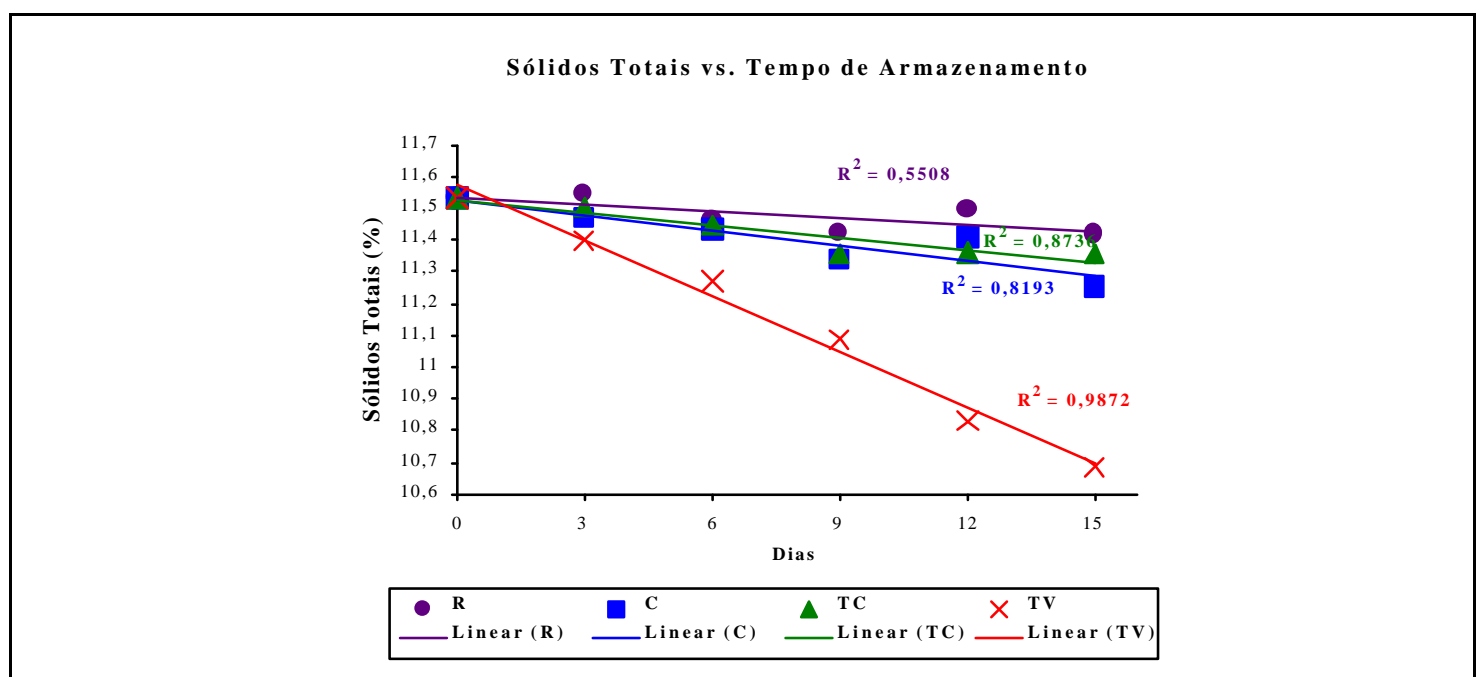

Figura 2- Efeitos dos métodos de armazenamento refrigerado (R), congelado (C), temperatura controlada (TC) e temperatura variável (TV), em função do tempo, sobre a concentração de sólidos totais do leite 


\subsubsection{Contagem de células somáticas}

A contagem de células somáticas ( $\mathrm{x} 10^{3}$ células $/ \mathrm{mL}$ ), transformada em logaritmo natural (LCCS), foi influenciada pelos tratamentos, diferindo assim do LCCS da amostra "controle", como pode ser observado pelo contraste "controle vs. demais" $(\mathrm{P}<0,01)$ (Tabela 2).

Foi observado efeito do tempo para os armazenamentos refrigerado $(\mathrm{P}<0,05)$, com temperatura controlada e temperatura variável $(\mathrm{P}<0,01)$, mas não para $\mathrm{O}$ congelado (Tabela 3). Entretanto, a contagem de células somáticas (LCCS) apresentou declínios lineares significativos (Tabela 3), no decorrer do tempo, para todos os métodos de armazenamento e as inclinações das retas foram -0,01 para armazenamento $R$ $(\mathrm{P}<0,001),-0,07$ para TC $(\mathrm{P}<0,001),-0,23$ para TV $(\mathrm{P}<0,001)$ e $-0,006 \mathrm{LCCS} /$ dia para $\mathrm{C}$ $(\mathrm{P}<0,005)$. Para facilitar o entendimento da magnitude do efeito dos armazenamentos sobre a CCS, sua queda, sem transformação logarítmica, foi significativamente linear, sendo, respectivamente, de 3,15, 4,67, 22,86 e 34,61 CCS (x 10³ células/dia) para C, R, TC e TV.

Vale salientar que a CCS (sem transformação logarítmica) no dia 0 (controle) foi 546.900 e, ao final do experimento (dia 15) foi de 488.600, 450.700, 189.600 e 24.400 células, respectivamente, para os armazenamentos C, R, TC e TV. Observa-se que a maior queda da CCS foi apresentada pelas amostras mantidas sob temperatura variável. Entretanto, Monardes et al. (1996) não demonstraram interferência do tempo de armazenamento (3 ou 7 dias após a coleta) sobre a CCS. A deterioração da contagem de células somáticas com o tempo é esperada em condições de falta de resfriamento das amostras (Monardes et al., 1996). Kroger (1985) comenta que, apesar do uso de conservantes químicos nas amostras de leite, o DHIA (Dairy Herd Improvement Association) analisa 90\% das suas amostras dentro de 3 dias após a coleta, a fim de prevenir esse tipo de problema.

Para o LCCS, o contraste "resfriado vs. não-resfriado" $[(\mathrm{R}+\mathrm{C}) v s .(\mathrm{TC}+$ TV)] foi significativo $(\mathrm{P}<0,01)$ em todos os tempos: dia $3(6,22$ vs. 5,94\%), dia $6(6,27$ vs. 5,70\%), dia 9 (6,22 vs. 5,16\%), dia 12 (6,21 vs. 4,47\%) e dia $15(6,15$ vs. 4,20\%) 
(Tabela 4). Porém, Chavez et al. (1991) não relataram variação na CCS das amostras, quando refrigeradas, mas houve variação quando mantidas à temperatura ambiente ou em temperaturas elevadas.

Entretanto, no presente experimento, não houve diferença entre LCCS das amostras submetidas à refrigeração e ao congelamento (contraste "refrigerado vs. congelado") (Tabela 4). Desse modo, pode-se inferir que, quanto à contagem de células somáticas, não há diferença entre refrigerar ou congelar as amostras. Trabalhos conflitantes sobre congelamento foram encontrados na literatura. Timms et al. (1987) reportaram um aumento na CCS, enquanto uma diminuição foi reportada por Barkema et al. (1997) e por Gonzalo et al. (1993), esses últimos analisando leite de ovelha. Read Jr. et al. (1969) congelaram amostras de leite a $-20^{\circ} \mathrm{C}$ e as armazenaram por 3, 7, 14 e 28 dias. As amostras evidenciaram variação de 13 a $84 \%$, quando comparadas às leituras de Oh, antes do congelamento.

Farrant (1980) relatou que as taxas de sobrevivência das células somáticas foram maiores para amostras congeladas a $-80^{\circ} \mathrm{C}$ do que para as congeladas a $-20^{\circ} \mathrm{C}$. Também observaram que o congelamento e o descongelamento lentos, como ocorre em freezer comercial, resultaram em mais danos às células. Para explicar tal diminuição na CCS com o congelamento, Barkema et al. (1997) propuseram que essa diminuição pode ter sido causada pela degeneração nuclear após o congelamento, resultando em uma absorção menor do corante específico para DNA durante o processo de leitura do equipamento de infravermelho. Eles, ainda, propõem que o congelamento do leite, logo após a sua amostragem, seria interessante por diminuir a probabilidade de supercrescimento de microorganismos e por desacelerar ou deter os componentes autolíticos que mudam a composição do leite.

O contraste "temperatura controlada vs. temperatura variável" (TC vs. TV) também mostrou significância $(\mathrm{P}<0,01)$ em todos os tempos. Nota-se que a queda no LCCS foi muito mais acentuada quando as amostras foram mantidas em temperatura variável do que em temperatura controlada.

O efeito do tempo entre amostragem e análise do leite na redução da contagem de células somáticas foi mais severo sob condições não-resfriadas, mas ainda 
esteve presente nas amostras submetidas ao resfriamento (refrigeração e congelamento). Tal observação sugere que o conservante empregado nas amostras (bronopol), sem uso de inibidores de leveduras e fungos, não seria tão efetivo para ser usado em amostras não-resfriadas em condições climáticas muito quentes, como postulado por Monardes et al. (1996). Esses pesquisadores observaram maiores valores de CCS (278.000 células $/ \mathrm{mL}$ ) para amostras que sofreram refrigeração completa (logo após a coleta, durante transporte e no laboratório) em relação às amostras não-refrigeradas (243.000 células $/ \mathrm{mL})$.

Os efeitos dos métodos de armazenamento, em função do tempo, sobre a contagem de células somáticas, transformada em logaritmo natural ou sem transformação, estão apresentados na Figura 3.

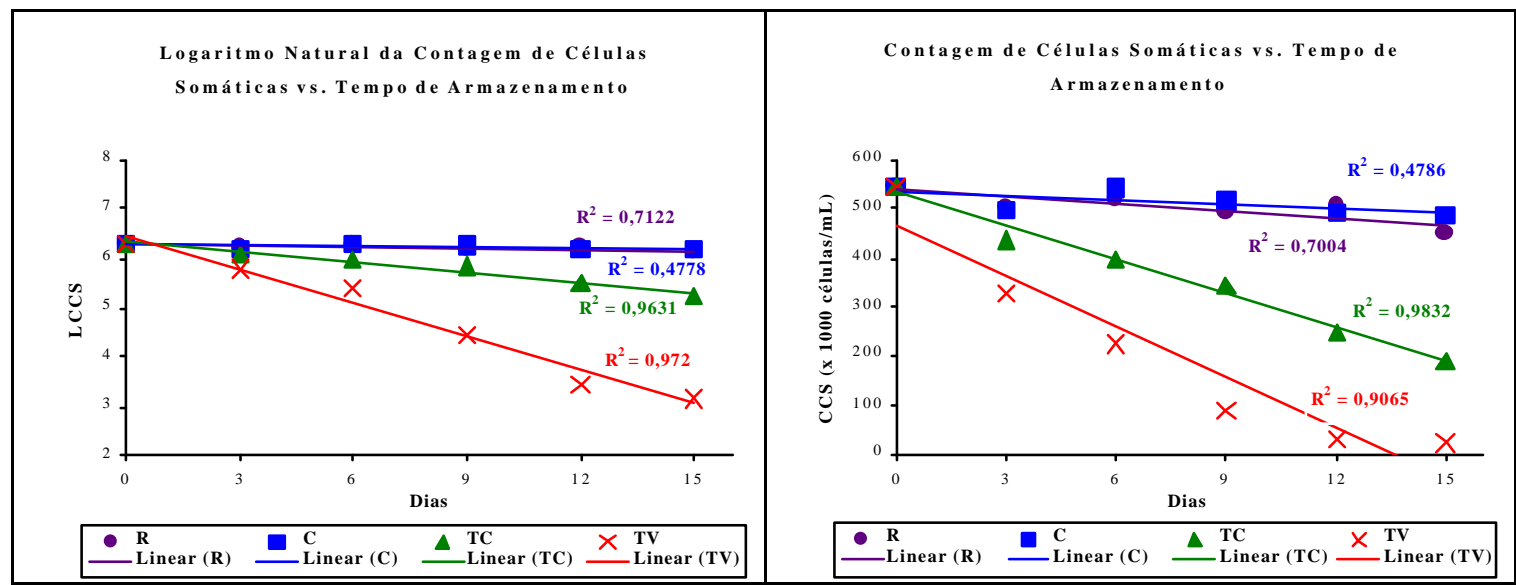

Figura 3- Efeitos dos métodos de armazenamento refrigerado (R), congelado (C), temperatura controlada (TC) e temperatura variável (TV), em função do tempo, sobre a contagem de células somáticas transformada em logaritmo natural (LCCS) ou sem transformação (CCS x $10^{3}$ células $/ \mathrm{mL}$ )

\subsubsection{Nitrogênio uréico no leite}

Observa-se, por intermédio do contraste "controle vs. demais" (Tabela 2), que a concentração de nitrogênio uréico no leite (NUL) foi afetada $(\mathrm{P}<0,01)$ pelos tratamentos, diferindo do controle. 
O NUL apresentou falta de ajuste para as equações linear e quadrática, em função do tempo, para todos os métodos de armazenamento (Tabela 3). Apesar de não ser significativa a interação entre método e tempo de armazenamento, o contraste "resfriado vs. não-resfriado" $[(\mathrm{R}+\mathrm{C})$ vs. $(\mathrm{TC}+\mathrm{TV})](\mathrm{P}<0,05)$ foi significativo apenas no dia 12 (5,91 vs. 6,08 mg/dL). O contraste "refrigerado vs. congelado" (R vs. C) foi significativo $(\mathrm{P}<0,01)$ no dia $3 \quad(5,99$ vs. $6,38 \mathrm{mg} / \mathrm{dL})$, assim como o contraste "temperatura controlada $v s$. temperatura variável" (TC vs. TV) $(\mathrm{P}<0,05)$ no mesmo dia (5,97 vs. 6,27mg/dL) (Tabela 4). Entretanto, pode-se notar que, no $3^{\mathrm{o}}$ dia após a amostragem, as leituras de NUL apresentam valores mais elevados em relação ao dia 0 e aos dias subseqüentes.

Isso pode ser devido a algum problema relacionado ao equipamento no momento da análise; entretanto, não se pode fazer tal assertiva, pois não houve constatação de irregularidades no momento. Caso não houvesse ocorrido tal elevação nas concentrações de NUL no referido dia, talvez fosse possível observar um aumento em sua concentração, para todos os métodos de armazenamento, iniciando com 5,66 no dia 0 e finalizando, em média, com $6,33 \mathrm{mg} / \mathrm{dL}$ no dia 15 . Uma possível explicação para esse aumento poderia ser a presença de bactérias proteolíticas produzindo amônia, o que poderia interferir na reação enzimática (Oltner \& Sjaunja, 1982).

Resultados conflitantes sobre o armazenamento das amostras foram encontrados na literatura. Oltner \& Sjaunja (1982), Miettinen \& Juvonen (1990) e Carlsson \& Bergstrom (1994), usando métodos indiretos de análise química, relataram que as concentrações de uréia no leite não sofreram mudanças por até 7 dias, quando refrigeradas $\left(4^{\circ} \mathrm{C}\right)$. Entretanto, Eicher et al. (1999) observaram maiores concentrações de uréia após 1 semana de refrigeração ( $8,1 \%$ de variação), em amostras analisadas por infravermelho.

Por sua vez, Godden et al. (2000) observaram que as concentrações de uréia no leite permaneceram inalteradas em amostras congeladas por até 3 dias, mas foram elevadas em amostras congeladas por 4 ou 7 dias $\left(-18^{\circ} \mathrm{C}\right)$. Sendo assim, sugerem que o congelamento por um curto período (por exemplo, durante o transporte para o laboratório) não deve interferir na acurácia dos resultados de uréia no leite. Eicher et al. 
(1999) observaram maiores concentrações de uréia, após 1 mês de congelamento $(26,7 \%$ de variação), em amostras analisadas por infravermelho.

Essas diferenças observadas entre os estudos podem ser, parcialmente, atribuídas a mudanças no conteúdo de outros componentes do leite, conhecidamente afetados pelo congelamento. Variações nas concentrações de cada componente do leite interferem, até certo ponto, na leitura dos outros componentes. Uma mudança na conceentração de um componente sólido do leite, enquanto a concentração dos outros permanece inalterada, é equivalente a um deslocamento de água. Visto que a absortividade da água é alta na região infravermelha, isso, geralmente, resulta em um sinal decrescido, fazendo com que as absortividades líquidas dos componentes interferentes sejam, principalmente, negativas (Biggs, 1967).

Os efeitos dos métodos de armazenamento, em função do tempo, sobre as concentrações de nitrogênio uréico no leite (mg/dL) estão apresentados na Figura 4.

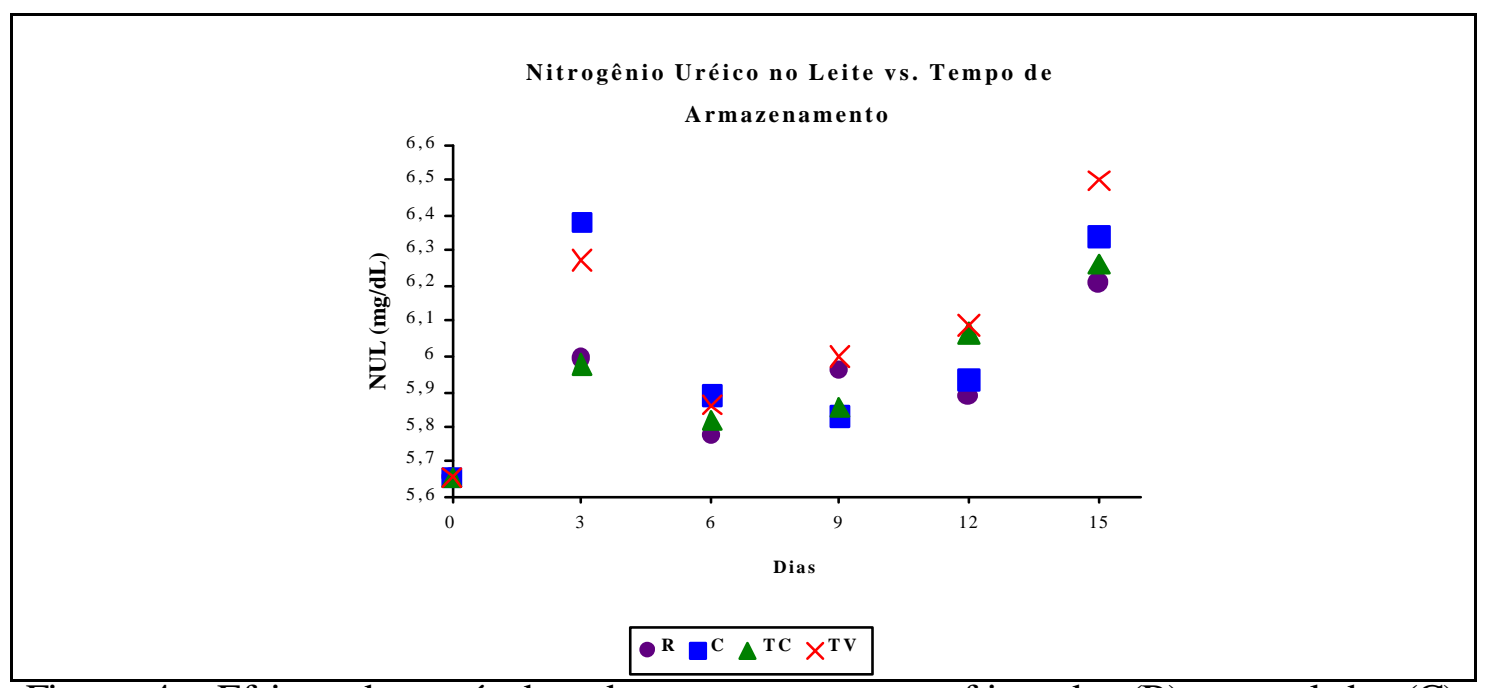

Figura 4- Efeitos dos métodos de armazenamento refrigerado (R), congelado (C), temperatura controlada (TC) e temperatura variável (TV), em função do tempo, sobre a concentração de nitrogênio uréico no leite (NUL) em mg/dL 


\subsection{Conclusões}

A refrigeração e o congelamento foram as melhores opções para o armazenamento das amostras de leite. Contudo, as amostras devem ser analisadas até 3 dias após sua coleta, para assegurar que os resultados da análise de leite, principalmente, da contagem de células somáticas e da gordura sejam confiáveis. 


\section{ESTUDO DOS FATORES NÃO-NUTRICIONAIS QUE AFETAM AS CONCENTRAÇÕES DE NITROGÊNIO URÉICO NO LEITE}

\section{Resumo}

O presente estudo teve por objetivo investigar a influência de fatores nãonutricionais sobre as concentrações de nitrogênio uréico no leite (NUL), com o intuito de contribuir para a sua avaliação como um indicador da eficiência da utilização das dietas para as vacas leiteiras. Foram utilizadas 7.006 observações, provenientes de 855 vacas da raça Holandesa, pertencentes a um rebanho comercial do estado de São Paulo, referentes ao período compreendido entre setembro de 2000 e janeiro de 2002. Dados zootécnicos sobre produção de leite, peso vivo do animal, número de dias em lactação (DEL) e número de lactações (NL) foram coletados no dia da amostragem de leite. Amostras de leite foram coletadas mensalmente, na ordenha da manhã, e encaminhadas ao laboratório, para determinação das concentrações de gordura, proteína, lactose, sólidos totais e nitrogênio uréico no leite, bem como contagem de células somáticas (CCS). Foram também criadas as variáveis produção de leite $(\mathrm{kg})$ corrigida para $4 \%$ de gordura, produção $(\mathrm{kg})$ de gordura, proteína, lactose e sólidos totais e relação gordura/proteína. Foram realizadas análises de regressão linear simples, usando os dados coletados como variáveis independentes e as concentrações de nitrogênio uréico no leite como variável dependente, assim como análises de correlação linear simples. A concentração média de NUL foi de $13,3 \mathrm{mg} / \mathrm{dL}$ e a produção de leite média foi de 35,8 $\mathrm{kg} /$ dia, com 3,2\% de gordura, 3,1\% de proteína, 4,7\% de lactose e 11,9\% de sólidos totais. A concentração de gordura, proteína, lactose e sólidos totais e o LCCS 
$(\ln (\mathrm{CCS}+1))$ apresentaram associação negativa, enquanto a produção $(\mathrm{kg})$ de leite, de lactose e de sólidos totais $(\mathrm{kg})$ apresentaram associação positiva e significativa com a concentração de NUL. A produção de leite corrigida para $4 \%$ de gordura, DEL, NL e produção $(\mathrm{kg})$ de gordura e proteína afetaram a concentração de NUL, porém não houve ajuste da equação linear para explicar tais associações. Entretanto, o peso vivo e a relação gordura/proteína não afetaram as concentrações de NUL. Dentre os fatores nãonutricionais, a produção de leite, a concentração de proteína do leite e a produção em kg de lactose foram os fatores que mais afetaram as concentrações de nitrogênio uréico no leite.

\section{STUDY OF NON-NUTRITIONAL FACTORS THAT AFFECT MILK UREA NITROGEN CONCENTRATIONS}

\section{Summary}

The objective of this study was to investigate further the influence of nonnutritional factors on milk urea nitrogen (MUN) concentrations, aiming to contribute to MUN assessment as an indicator of the utilization efficiency of diets for dairy cows. It was used 7,006 observations, coming from 855 Holstein cows, belonging to a commercial herd in Sao Paulo State (Brazil), from September/2000 to January/2002. Milk production, body weight, days in milk and lactation number were collected on the milk sampling days. Milk was sampled monthly, during morning milking, for analyses of milk fat, protein, lactose and total solids concentrations, milk urea nitrogen and somatic cells count (SCC). Variables were also created: $4 \%$ fat corrected milk, milk components production $(\mathrm{kg})$ (fat, protein, lactose and total solids) and fat/protein ratio. Simple linear regression analyses, using all other collected data as independent variable and MUN as dependent variable, were made, as well as, simple linear correlation analyses. Mean MUN was $13.3 \mathrm{mg} / \mathrm{dL}$ and mean milk production was $35.8 \mathrm{~kg} / \mathrm{day}$, with 
$3.2 \%$ of fat, $3.1 \%$ of protein, $4.7 \%$ of lactose and $11.9 \%$ of total solids. Fat, protein, lactose and total solids concentration and SCC $(\ln (\operatorname{SCC}+1))$ showed negative association, whereas production $(\mathrm{kg})$ of milk, lactose and total solids showed significant positive association with MUN concentration. Fat and protein production $(\mathrm{kg}), 4 \%$ fat corrected milk production ( $\mathrm{kg}$ ), days in milk and lactation number affected MUN concentration, however there was lack of fit for the linear equation to explain those associations. Nevertheless, body weight and fat/protein ratio did not affect MUN concentrations. Among the non-nutritional factors, milk production, milk protein and lactose production were the factors that most affected milk urea nitrogen concentrations.

\subsection{Introdução}

A uréia é a principal forma de excreção de nitrogênio nos mamíferos. Desde longo tempo, sabe-se que a concentração de nitrogênio uréico no sangue reflete o uso ineficiente da proteína bruta dietária pelos ruminantes (Lewis, 1957). A concentração de nitrogênio uréico no leite (NUL) apresenta alta correlação com a concentração de nitrogênio uréico no plasma ou no sangue. Desse modo, a concentração de NUL vem sendo proposta como indicador para o monitoramento da nutrição protéica (Jonker et al., 1999; Kohn, 2000), principalmente da adequação da relação entre nitrogênio (ou proteína) e energia da dieta de vacas em lactação (Oltner \& Wiktorsson, 1983; Oltner et al., 1985; Broderick \& Clayton, 1997).

Para a determinação da concentração de NUL, as amostras são coletadas de forma não-invasiva e direta, por meio da amostragem de leite durante as ordenhas, representando, assim, um indicador simples, rápido e barato de avaliação do "status" nutricional de vacas em lactação (Roseler et al., 1993; Butler et al., 1995). Esse indicador, então, vem sendo usado como ferramenta auxiliar no ajuste da dieta de vacas em lactação.

Contudo, para interpretar os dados de concentração de nitrogênio uréico no leite corretamente é importante levar em consideração outros fatores que vêm apresentando resultados conflitantes entre as mais diversas pesquisas, além da dieta das 
vacas: produção de leite (Oltner et al., 1985; Carlsson et al., 1995), idade da vaca (Carlsson et al., 1995), estágio da lactação (Carlsson et al., 1995) e peso vivo (Oltner et al., 1985; Jonker et al., 1998). As concentrações de proteína (Jonker et al., 1999) e gordura do leite (Jonker et al., 1998) também podem alterar a concentração de NUL. Variações diurnas da concentração de NUL foram encontradas por alguns pesquisadores (Carlsson \& Bergström, 1994; Gustafsson \& Palmquist, 1993; Roseler et al., 1993), assim como variações sazonais também foram relatadas por Carlsson \& Pehrson (1993).

Ademais, a maioria dos estudos mencionados acima foi conduzida sob condições experimentais. Entretanto, a associação entre NUL e outras variáveis deveria ser determinada sob condições de campo, usando procedimentos de rebanhos comerciais. Em face de resultados conflitantes sobre quais fatores afetam as concentrações de nitrogênio uréico no leite, o objetivo deste estudo foi avaliar, mais profundamente, a influência de fatores não-nutricionais sobre NUL, em condições de rebanho comercial.

\subsection{Material e Métodos}

\subsubsection{Coleta de dados}

Neste estudo, foram utilizadas 7.006 observações, provenientes de 855 vacas da raça Holandesa, pertencentes ao rebanho da Fazenda Colorado, situada no município de Araras, estado de São Paulo. Essas observações foram coletadas no período compreendido entre setembro de 2000 e janeiro de 2002.

Os animais foram confinados em estábulo do tipo "free-stall", dotado de ventiladores e aspersores, acionados automaticamente quando a temperatura ultrapassava $23^{\circ} \mathrm{C}$. Após o parto, os animais eram ordenhados em sala do tipo "espinha de peixe", 2 x 12, linha baixa, com sistema de coleta de dados AFIMILK® - SAE AFIKIM, em que cada animal é identificado e tem sua produção de leite registrada 
diariamente. Os dados diários de produção de leite eram automaticamente lançados em um software de controle leiteiro para avaliação gerencial do rebanho.

Os animais eram alimentados 7 vezes ao dia, sendo o primeiro fornecimento às $5 \mathrm{~h}$ e o último, às $21 \mathrm{~h}$; recebiam dieta total e única, composta de silagem de milho, silagem pré-secada de gramínea, farelo de soja, gérmen de milho, silagem de grão úmido de milho, farelo de glúten de milho, polpa cítrica e mistura mineral, em que o volumoso correspondeu a $48 \%$ da dieta em MS. Para alimentação do rebanho, foi utilizado vagão de mistura total (TMR) de 10 m, com desensilador e balança eletrônica. A composição estimada média da dieta foi $50,2 \%$ de matéria seca (MS), 16,9\% de proteína bruta (\% MS), 4,5\% de extrato etéreo (\% MS), 18,6\% de fibra em detergente ácido (\% MS), 31,4\% de fibra em detergente neutro (\% MS), 40,2\% de carboidratos não-estruturais (\% MS), 6,6\% de matéria mineral (\% MS) e 1,75 Mcal/kg de energia líquida para lactação, sendo o consumo projetado de matéria seca de $23,0 \mathrm{~kg} /$ dia.

Das 8.844 observações coletadas, foram utilizadas 7.006, abrangendo vacas com 5 lactações ou menos, com até 305 dias em lactação e concentrações de NUL inferiores a $25 \mathrm{mg} / \mathrm{dL}$. Dados zootécnicos sobre produção de leite $(\mathrm{kg})$, peso vivo do animal (kg), número de dias em lactação (DEL) e número de lactações (NL) foram coletados no dia da amostragem de leite.

A produção de leite corrigida para $4 \%$ de gordura (LCG4\%) foi calculada pela seguinte equação: $(0,4 * \mathrm{~kg}$ de leite produzido $)+\left(15^{*} \mathrm{~kg}\right.$ de gordura produzida), de acordo com NRC (1989). A produção, em kg, dos componentes do leite (gordura, proteína, lactose e sólidos totais) foi obtida da multiplicação da produção de leite pela respectiva percentagem do componente do leite, dividindo-se esse número por 100. A relação gordura/proteína (rel. G/P) foi obtida da divisão entre a percentagem de gordura pela de proteína do leite.

Amostras de leite foram coletadas mensalmente, sempre na ordenha da manhã, transferidas diretamente do medidor para os frascos de coleta $(60 \mathrm{~mL})$, cada um contendo duas pastilhas de bronopol (largo espectro) como conservante e homogeneizadas por, no mínimo, 15 segundos. Foram, então, encaminhadas à Clínica do Leite do Departamento de Zootecnia da Escola Superior de Agricultura "Luiz de 
Queiroz"/ Universidade de São Paulo, para determinação das concentrações de gordura, proteína, lactose, sólidos totais (ST) (\%) e NUL (mg/dL), bem como contagem de células somáticas (CCS) (x $10^{3}$ células $\left./ \mathrm{mL}\right)$.

As concentrações de gordura, proteína, lactose e sólidos totais foram determinadas por leitura de absorção infravermelha pelo equipamento Bentley $2000 \AA$ (Bentley Instruments, 1995a) e a CCS foi executada por citometria fluxométrica pelo equipamento Somacount $300 \AA$ (Bentley Instruments, 1995b). As concentrações de NUL foram determinadas utilizando-se o equipamento ChemSpeck 150ß, por um método enzimático e espectrofotométrico de trans-reflectância (Bentley Instruments, 1998).

\subsubsection{Análise estatística}

Primeiramente, foi realizada a análise descritiva de todas as variáveis estudadas, apresentando o número amostral (n), média e erro-padrão da média.

A contagem de células somáticas (x $10^{3}$ células $/ \mathrm{mL}$ ) foi transformada em logaritmo natural (LCCS) pela equação $\ln (\mathrm{CCS}+1)$, pois não possui distribuição normal (Godden et al., 2001b).

Análises de correlação linear simples foram realizadas entre as variáveis estudadas, por meio do PROC CORR do SAS (1999), a partir do qual foram utilizadas as correlações entre a concentração de NUL ou de produção de leite e as outras variáveis estudadas.

Análises de regressão linear simples foram realizadas pelo PROC REG do SAS (1999), usando os dados coletados como variáveis independentes e as concentrações de NUL como variável dependente. Entretanto, ao se considerar que existem repetições das variáveis estudadas, os modelos só poderiam explicar os valores médios de cada variável. Portanto, os coeficientes de determinação $\left(\mathrm{R}^{2}\right)$ foram recalculados para exprimir melhor os efeitos das variáveis sobre as concentrações de NUL. Para esses cálculos, foram realizadas análises de regressão linear simples, considerando as variáveis independentes como variáveis classificatórias, ou seja, cada valor se torna uma classe, que é o máximo possível de se explicar considerando tal 
variável. A partir daí, a soma de quadrados do modelo de regressão foi dividida pela soma de quadrados do modelo analisado com a variável classificatória para obtenção do coeficiente de determinação $\left(\mathrm{R}^{2}\right)$ correto (Coldebella $\left.{ }^{1}, 2002\right)$. O teste de falta de ajuste da equação linear foi realizado de acordo com Neter et al. (1996) e Souza (1998).

\subsection{Resultados e Discussão}

Os dados relativos às médias encontradas no experimento estão apresentados na Tabela 1. A média geral de concentração de nitrogênio uréico no leite encontrada foi de 13,30 mg/dL (amplitude de 2,22 a 24,92). Os animais apresentaram produção média diária de leite de $35,81 \mathrm{~kg}$ e produção de leite corrigida para $4 \%$ de gordura de 31,29 kg, com média de 2,19 lactações e 153,70 dias em lactação, pesando 646,30 kg, em média. A composição do leite apresentou, em média, 3,20\% de gordura, $3,07 \%$ de proteína, $4,74 \%$ de lactose e $11,86 \%$ de sólidos totais. As produções médias diárias de gordura, proteína, lactose e sólidos totais foram de 1,13, 1,09, 1,70 e 4,22 kg, respectivamente. A contagem média de células somáticas foi de 266 mil células $/ \mathrm{mL}$ e transformada em logaritmo natural foi de 4,25 (LCCS). A relação gordura/proteína média foi de 1,05 .

\footnotetext{
${ }^{1}$ COLDEBELla, A. (EMBRAPA Suínos e Aves, Concórdia/SC). Comunicação pessoal, 2002.
} 
Tabela 1. Análise descritiva das variáveis estudadas

\begin{tabular}{lrrr}
\hline Variável & n & \multicolumn{1}{c}{ média } & EPM \\
\hline Nitrogênio uréico no leite (mg/dL) & 7.006 & 13,30 & 0,0410 \\
Produção de leite (kg/dia) & 7.000 & 35,81 & 0,1041 \\
Leite corrigido para 4\% de gordura (kg/dia) & 7.000 & 31,29 & 0,0962 \\
Peso corporal (kg) & 3.868 & 646,30 & 1,4595 \\
Número de lactações & 7.006 & 2,19 & 0,0148 \\
Dias em lactação & 7.006 & 153,70 & 0,9755 \\
Gordura (\%) & 7.006 & 3,20 & 0,0098 \\
Proteína (\%) & 7.006 & 3,07 & 0,0039 \\
Lactose (\%) & 7.006 & 4,74 & 0,0038 \\
Sólidos totais (\%) & 7.006 & 11,86 & 0,0122 \\
Produção de gordura (kg/dia) & 7.000 & 1,13 & 0,0043 \\
Produção de proteína (kg/dia) & 7.000 & 1,09 & 0,0029 \\
Produção de lactose (kg/dia) & 7.000 & 1,70 & 0,0051 \\
Produção de sólidos totais (kg/dia) & 7.000 & 4,22 & 0,0117 \\
LCCS (ln (CCS+1)) & 7.006 & 4,25 & 0,0179 \\
Relação gordura/proteína & 7.006 & 1,05 & 0,0033 \\
\hline n = número amostral; EPM = erro-padrão da média; LCCS= logaritmo natural (contagem de células \\
somáticas +1).
\end{tabular}

Por meio da análise de correlação linear simples (Tabela 2), observa-se que a variável mais correlacionada positivamente com NUL foi a produção de leite $(\mathrm{r}=0,2670)$. Outras variáveis também apresentaram coeficientes de correlação positivos bem próximos aos da produção de leite; entre elas, estão: a produção de lactose $(\mathrm{r}=0,2337)$ e de sólidos totais $(\mathrm{r}=0,2132)$ e produção de leite corrigida para $4 \%$ de gordura $(\mathrm{r}=0,2036)$. Entretanto, a percentagem de proteína apresentou um coeficiente de correlação negativo ( $\mathrm{r}=-0,2016)$, o que significa que, ao aumentar a concentração de NUL, a percentagem de proteína do leite diminui, ou vice-versa.

Pela análise de correlação entre a produção de leite e as outras variáveis estudadas (Tabela 2), observa-se uma alta correlação positiva entre aquela variável e a produção de lactose $(\mathrm{r}=0,9649)$ e sólidos totais $(\mathrm{r}=0,9323)$. Isso explica porque a concentração de NUL está correlacionada positivamente com a produção de leite e, conseqüentemente, com a produção de lactose e de sólidos totais, uma vez que essas últimas estão altamente correlacionadas com a produção de leite. Portanto, entre essas variáveis, pode-se afirmar que a concentração de NUL está positivamente correlacionada com a produção de leite e não se faz necessário preocupar-se com sua correlação com a 
produção de lactose e sólidos totais, pois essas estão altamente correlacionadas com a produção de leite.

Tabela 2. Análise de correlação linear simples entre a concentração de nitrogênio uréico no leite e produção de leite e as outras variáveis estudadas

\begin{tabular}{lcccccc}
\hline NUL & NUL & leite & lactkg & STkg & LCG4\% & prot \\
r & 1,0000 & 0,2670 & 0,2337 & 0,2132 & 0,2036 & $-0,2016$ \\
Prob. & & 0,0001 & 0,0001 & 0,0001 & 0,0001 & 0,0001 \\
& protkg & ST & DEL & gordkg & NL & LCCS \\
r & 0,1925 & $-0,1697$ & $-0,1472$ & 0,1302 & 0,1275 & $-0,1266$ \\
Prob. & 0,0001 & 0,0001 & 0,0001 & 0,0001 & 0,0001 & 0,0001 \\
& lact & gord & peso & rel. g/p & & \\
r & $-0,0938$ & $-0,0826$ & 0,0216 & $-0,0085$ & & \\
Prob. & 0,0001 & 0,0001 & 0,1794 & 0,4789 & & \\
& & & & & & \\
leite & & & & & & \\
& leite & lactkg & STkg & protkg & LCG4\% & gordkg \\
r & 1,0000 & 0,9649 & 0,9323 & 0,9009 & 0,8436 & 0,6077 \\
Prob. & & 0,0001 & 0,0001 & 0,0001 & 0,0001 & 0,0001 \\
& prot & ST & NUL & NL & DEL & LCCS \\
r & $-0,4232$ & $-0,3150$ & 0,2670 & 0,2477 & $-0,2465$ & $-0,2096$ \\
Prob. & 0,0001 & 0,0001 & 0,0001 & 0,0001 & 0,0001 & 0,0001 \\
& gord & peso & rel. g/p & lact & & \\
r & $-0,2072$ & 0,1421 & $-0,0375$ & 0,0221 & & \\
Prob. & 0,0001 & 0,0001 & 0,0017 & 0,0640 & &
\end{tabular}

NUL= nitrogênio uréico no leite $(\mathrm{mg} / \mathrm{dL}) ; \mathrm{r}=$ coeficiente de correlação; Prob. = probabilidade estatística; leite = produção de leite $(\mathrm{kg} / \mathrm{dia})$; lactkg = produção de lactose em $\mathrm{kg} / \mathrm{dia} ; \mathrm{STkg}$ = produção de sólidos totais em $\mathrm{kg} / \mathrm{dia}$; $\mathrm{LCG} 4 \%$ = produção de leite corrigida para $4 \%$ de gordura (kg/dia); prot = proteína do leite $(\%) ;$ protkg = produção de proteína em $\mathrm{kg} /$ dia; $\mathrm{ST}=$ sólidos totais (\%); DEL = dias em lactação; gordkg = produção de gordura em $\mathrm{kg} / \mathrm{dia} ; \mathrm{NL}=$ número de lactações; LCCS = ln (contagem de células somáticas +1$)$; lact $=$ lactose $(\%) ;$ gord $=$ gordura do leite $(\%) ;$ peso = peso corporal $(\mathrm{kg}) ;$ rel. $\mathrm{g} / \mathrm{p}=$ relação gordura/proteína.

Ferguson et al. (1997) obtiveram coeficientes de correlação entre NUL e as variáveis estudadas de: 0,178 para produção de leite, -0,136 para número de dias em lactação, 0,0135 para concentração de gordura no leite, -0,138 para concentração de proteína no leite e -0,240 para escore linear de CCS. Nota-se que os coeficientes de correlação entre as variáveis encontrados por tais autores foram menores que os do 
presente estudo, excetuando-se para a CCS, que foi o dobro. Cabe, ainda, apontar que, apesar de os coeficientes serem diferentes, o sentido das associações (positivo ou negativo), encontrado por Ferguson et al. (1997) e pelo presente estudo, foi similar.

Os efeitos individuais das variáveis estudadas sobre as concentrações de nitrogênio uréico no leite, analisados por regressão linear simples, estão apresentados na Tabela 3.

Tabela 3. Equações, coeficientes de determinação da análise de regressão linear simples e probabilidades, usando as concentrações de nitrogênio uréico no leite como variável independente

\begin{tabular}{llrll}
\hline Variável & \multicolumn{1}{c}{ Equação } & $\mathbf{R}^{2}$ & Prob(1) & Prob(2) \\
\hline Leite $(\mathrm{kg} /$ dia) & $\mathrm{NUL}=9,52+0,1054$ leite & 0,6502 & $<0,0001$ & 0,2120 \\
LCG4\% (kg/dia) & $\mathrm{NUL}=10,58+0,0896 \mathrm{LCG} 4 \%$ & 0,3322 & $<0,0001$ & $<0,0001$ \\
Peso $(\mathrm{kg})$ & $\mathrm{NUL}=13,46+0,00079$ peso & 0,0040 & 0,1794 & 0,4270 \\
DEL & $\mathrm{NUL}=14,25-0,0062$ DEL & 0,2384 & $<0,0001$ & $<0,0001$ \\
NL & $\mathrm{NUL}=12,52+0,3537 \mathrm{NL}$ & 0,5310 & $<0,0001$ & $<0,0001$ \\
Gordura $(\%)$ & $\mathrm{NUL}=14,41-0,3466$ gordura & 0,0952 & $<0,0001$ & 0,8428 \\
Proteína $(\%)$ & $\mathrm{NUL}=19,73-2,0976$ proteína & 0,6000 & $<0,0001$ & 0,6684 \\
Lactose $(\%)$ & $\mathrm{NUL}=18,05-1,0022$ lactose & 0,1967 & $<0,0001$ & 0,0556 \\
ST $(\%)$ & $\mathrm{NUL}=20,05-0,5696$ ST & 0,2564 & $<0,0001$ & 0,3786 \\
Gordkg & $\mathrm{NUL}=11,90+1,2330$ gordkg & 0,2853 & $<0,0001$ & 0,0029 \\
Protkg & $\mathrm{NUL}=10,30+2,7571$ protkg & 0,5562 & $<0,0001$ & 0,0077 \\
Lactkg & $\mathrm{NUL}=10,07+1,8976$ lactkg & 0,6191 & $<0,0001$ & 0,7590 \\
STkg & $\mathrm{NUL}=10,13+0,7510$ STkg & 0,3680 & $<0,0001$ & 0,3238 \\
LCCS & $\mathrm{NUL}=14,53-0,2902$ LCCS & 0,1994 & 0,0001 & 0,9000 \\
Rel. G/P & $\mathrm{NUL}=13,41-0,1063$ rel G/P & 0,0020 & 0,4775 & 0,0145
\end{tabular}

$\mathrm{R}^{2}$ = coeficiente de determinação; Prob(1) = probabilidade estatística de o coeficiente angular da reta ("slope") diferir de zero; $\operatorname{Prob}(2)=$ probabilidade estatística da falta de ajuste da equação linear; Leite = produção de leite; LCG4\% = produção de leite corrigida para 4\% de gordura; DEL = dias em lactação; NL = número de lactações; Gordkg = produção de gordura em kg; Protkg = produção de proteína em kg; Lactkg = produção de lactose em $\mathrm{kg} ; \mathrm{STkg}=$ produção de sólidos totais em $\mathrm{kg} ; \mathrm{LCCS}=\ln$ (contagem de células somáticas +1$)$; Rel. G/P = relação gordura/proteína; NUL= nitrogênio uréico no leite (mg/dL). 
Pelo coeficiente de determinação $\left(\mathrm{R}^{2}=0,6502\right)$, constatou-se que a produção de leite foi a variável que mais afetou a concentração de nitrogênio uréico no leite (Tabela 3). Não foi observada falta de ajuste da equação linear para essa variável ( $\mathrm{P}=0,2120$ ), ou seja, a equação linear explica bem o seu efeito sobre NUL (Figura 1). Assim, observa-se que a cada aumento de $1 \mathrm{~kg}$ na produção de leite, há um aumento de 0,10 mg/dL na concentração de NUL ( $<<0,0001)$. Entretanto, Arunvipas et al. (2002) relataram que, a cada aumento de um litro na produção de leite/vaca/dia, há um aumento de $0,05 \mathrm{mg} / \mathrm{dL}$ na concentração de NUL, em que a média de NUL foi de $11,17 \mathrm{mg} / \mathrm{dL}$.

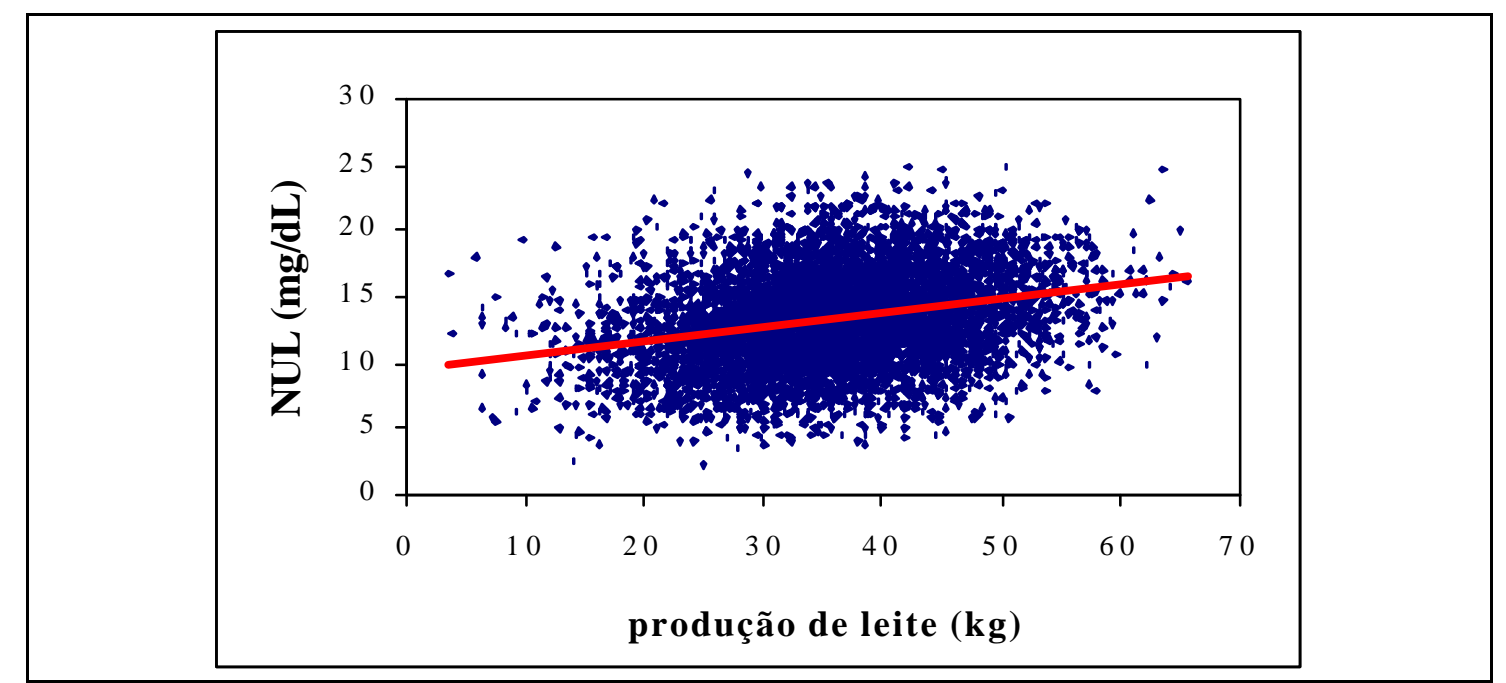

Figura 1 Efeito da produção de leite $(\mathrm{kg})$ sobre as concentrações de nitrogênio uréico no leite

Oltner et al. (1985) também observaram correlação positiva entre produção de leite e concentração de uréia no leite. Kaufmann (1982) encontrou uma relação similar, atribuindo-a ao aumento no conteúdo de proteína na dieta e ao aumento da produção de leite, em vez de apenas ao efeito da produção de leite. Por sua vez, a associação entre uréia no leite e produção, encontrada por Godden et al. (2001a), foi positiva, mas não-linear.

Oltner \& Wiktorsson (1983), Oltner et al. (1985) e Broderick \& Clayton (1997) sugeriram que o efeito da produção de leite sobre as concentrações de NUL é causado pela forte correlação entre produção de leite e relação proteína/energia na dieta. 
Chalupa (1984) e Oldham (1984) atribuíram tal associação positiva ao maior teor de proteína dietária consumido. A proteína suplementar pode aumentar a produção de leite por fornecer mais aminoácidos para a síntese de proteína do leite, aumentar a energia disponível a partir da deaminação dos aminoácidos ou alterar a eficiência de utilização dos nutrientes absorvidos (Chalupa, 1984).

MacLeod et al. (1984) reportaram que o aumento nos teores de proteína na dieta aumentou o consumo de matéria seca, resultando, indiretamente, em maior consumo de energia. Contudo, há um padrão de incrementos decrescentes, em que as respostas na produção de leite à proteína adicional, eventualmente, se tornam cada vez menores. Godden et al. (2001a) concluíram que a variabilidade na quantidade e qualidade dos alimentos pode explicar as diferenças na associação entre uréia no leite e produção de leite.

Entretanto, cabe ressaltar que, neste estudo, todas as vacas recebiam a mesma dieta, sem alterações relativas ao número de lactações, dias em lactação ou mesmo produção de leite. Desse modo, uma possível explicação para o aumento nas concentrações de NUL, em relação ao aumento na produção de leite, pode ser devido ao fato de que, o limitante para vaca de alta produção seria a energia. Assim, para ela alcançar a ingestão de energia necessária, aumentaria o consumo de matéria seca, ingerindo, assim, proteína em excesso, em relação à energia.

Os resultados de NUL do presente estudo estão de acordo com os estimados por Jonker et al. (1998) em que rebanhos produzindo entre 8.000 e $12.000 \mathrm{~kg}$ de leite/vaca/lactação apresentaram NUL variando entre 10 e 16 mg/dL, respectivamente. Dessa forma, tais pesquisadores defendem que os padrões de referência das concentrações de NUL devem levar em conta o potencial de produção de leite do rebanho e que esse é o principal fator a influenciar aquele parâmetro.

Entretanto, Trevaskis \& Fulkerson (1999) observaram que a produção de leite de vacas em pastejo foi negativamente relacionada à concentração de uréia no leite e atribuem esse fato a um resultado de diluição. Uma outra possível explicação para a relação negativa entre uréia no leite e produção seria que a taxa energética associada à conversão de quantidades excessivas de amônia em uréia pode contribuir para diminuir a 
energia disponível para produção de leite (Nelson, 1995). Entretanto, Gustafsson \& Carlsson (1993) e Eicher et al. (1999) não encontraram associações entre uréia no leite e produção de leite.

A produção de leite corrigida para $4 \%$ de gordura apresentou um coeficiente de determinação $\left(\mathrm{R}^{2}\right)$ de 0,3320 , valor esse igual à metade do $\mathrm{R}^{2}$ referente à produção de leite sem correção, explicando, assim, 33\% da variação de NUL. Apesar de ter sido observado que o coeficiente angular da reta difere de $0(\mathrm{P}<0,0001)$, nota-se falta de ajuste da equação linear para essa variável $(\mathrm{P}<0,0001)$ (Tabela 3). Godden et al. (2001a) também relataram associação positiva, mas não-linear, entre uréia no leite e a produção de leite corrigida para 3,5\% de gordura e também para a produção de leite corrigida para energia (3,5\% de gordura e 3,2\% de proteína). Eles propõem que, apesar de a relação parecer similar entre a uréia no leite e essas medidas de produção de leite, o ajuste do modelo foi melhor quando a produção corrigida para energia foi usada.

O peso corporal não afetou as concentrações de NUL ( $\mathrm{P}=0,1794)$, apesar da equação linear se ajustar bem para explicar as possíveis variações de NUL em função do peso corporal $(\mathrm{P}=0,4270)$ (Tabela 3$)$. $\mathrm{O}$ coeficiente de determinação também se apresentou baixo $\left(\mathrm{R}^{2}=0,0040\right)$, indicando que o peso corporal pouco explica a variação nas concentrações de NUL.

Esse resultado está em concordância com o Jonker et al. (1999), mostrando que menos de $3 \%$ da variação de NUL, em seu modelo, foi atribuída à variação no peso corporal. Eles complementam que a variação nas medições de peso corporal causada pelo enchimento gastrointestinal, o volume de leite na glândula mamária e os métodos de medições parece adicionar tanta variação nas predições de seu modelo original (Jonker et al., 1998) que sua inclusão não se justificou nesse modelo. Entretanto, Oltner et al. (1985) e Jonker et al. (1998) relataram que o peso corporal apresentou correlação negativa com as concentrações de NUL em vacas leiteiras em lactação.

Para as variáveis dias em lactação (DEL), número de lactações (NL) e relação gordura/proteína (rel. G/P), a equação linear não se adequou para explicar suas associações com NUL, pois apresentou falta de ajuste $(\mathrm{P}<0,02)$, como observada na 
Tabela 3. Entretanto, observou-se efeito significativo $(\mathrm{P}<0,001)$ dessas variáveis sobre NUL, excetuando-se a relação gordura/proteína $(\mathrm{P}=0,4775)$. Mas cabe observar que o coeficiente de determinação foi baixo para a relação gordura/proteína $\left(R^{2}=0,0020\right)$, enquanto, para dias em lactação e número de lactações, foram mais altos, de 0,2384 e 0,5310 , respectivamente.

Existem trabalhos conflitantes sobre a variação das concentrações de NUL entre os estágios de lactação. Bruckental et al. (1980), Emanuelson et al. (1993) e Carlsson et al. (1995) reportaram valores médios de uréia no leite mais baixos durante o primeiro mês de lactação em relação aos meses subseqüentes. Godden et al. (2001a) relataram uma associação positiva, mas não-linear entre uréia no leite e DEL, em que as concentrações de NUL foram mais baixas nos primeiros 60 dias, aumentando entre 60 e 150 e decrescendo após 150 dias em lactação. Diferenças em ingestão de matéria seca, adaptação microbiana do rúmen e capacidade absortiva podem ter contribuído para as diferenças na uréia no leite em diferentes estágios da lactação (Godden et al., 2001a). Arunvipas et al. (2002) relataram que a concentração de NUL foi baixa no 1 mês de lactação $(10,14 \mathrm{mg} / \mathrm{dL})$, elevou-se ao pico aos 4 meses de lactação $(11,80 \mathrm{mg} / \mathrm{dL})$ e decresceu ao fim da lactação $(10,56 \mathrm{mg} / \mathrm{dL})$.

Quanto ao número de lactações, os resultados do presente estudo concordam com os de alguns autores (Oltner et al., 1985; Canfield et al., 1990; Godden et al., 2001a), que sugeriram levar em consideração o número de lactações, pois vacas primíparas tiveram menor concentração de NUL do que as multíparas. Segundo os autores, isso pode ser devido ao fato de que os animais primíparos têm um direcionamento pronunciado para crescimento e podem, portanto, utilizar aminoácidos mais efetivamente.

Por sua vez, Jonker et al. (1998) observaram que vacas de primeira lactação apresentaram maiores concentrações estimadas de NUL, enquanto vacas multíparas apresentaram menores concentrações. Porém, Carlsson et al. (1995), Schepers \& Meijer (1998), Eicher et al. (1999) e Arunvipas et al. (2002) não reportaram diferenças na concentração de uréia no leite entre primíparas e multíparas. 
As concentrações de gordura, proteína, lactose e sólidos totais afetaram as concentrações de NUL ( $\mathrm{P}<0,0001)$. Observa-se pela Tabela 3 que a equação linear se ajusta bem para NUL em função da concentração de gordura $(\mathrm{P}=0,8428)$, proteína $(\mathrm{P}=0,6684)$ e sólidos totais $(\mathrm{P}=0,3786)$, mas quase há falta de ajuste para o efeito da lactose $(\mathrm{P}=0,0556)$. Pelo coeficiente de determinação, observa-se que, dentre os componentes do leite, a concentração de proteína foi a que mais explicou a variabilidade de NUL $\left(\mathrm{R}^{2}=0,6000\right)$ (Figura 2 ), sendo seguida pela percentagem de sólidos totais $\left(\mathrm{R}^{2}=0,2564\right)$, lactose $\left(\mathrm{R}^{2}=0,1967\right)$ e gordura $\left(\mathrm{R}^{2}=0,0952\right)$. A cada aumento de uma unidade percentual de proteína, sólidos totais, lactose e gordura do leite, observou-se um decréscimo na concentração de NUL de, aproximadamente, 2,10, 0,57, 1,0 e 0,35 $\mathrm{mg} / \mathrm{dL}$, respectivamente.

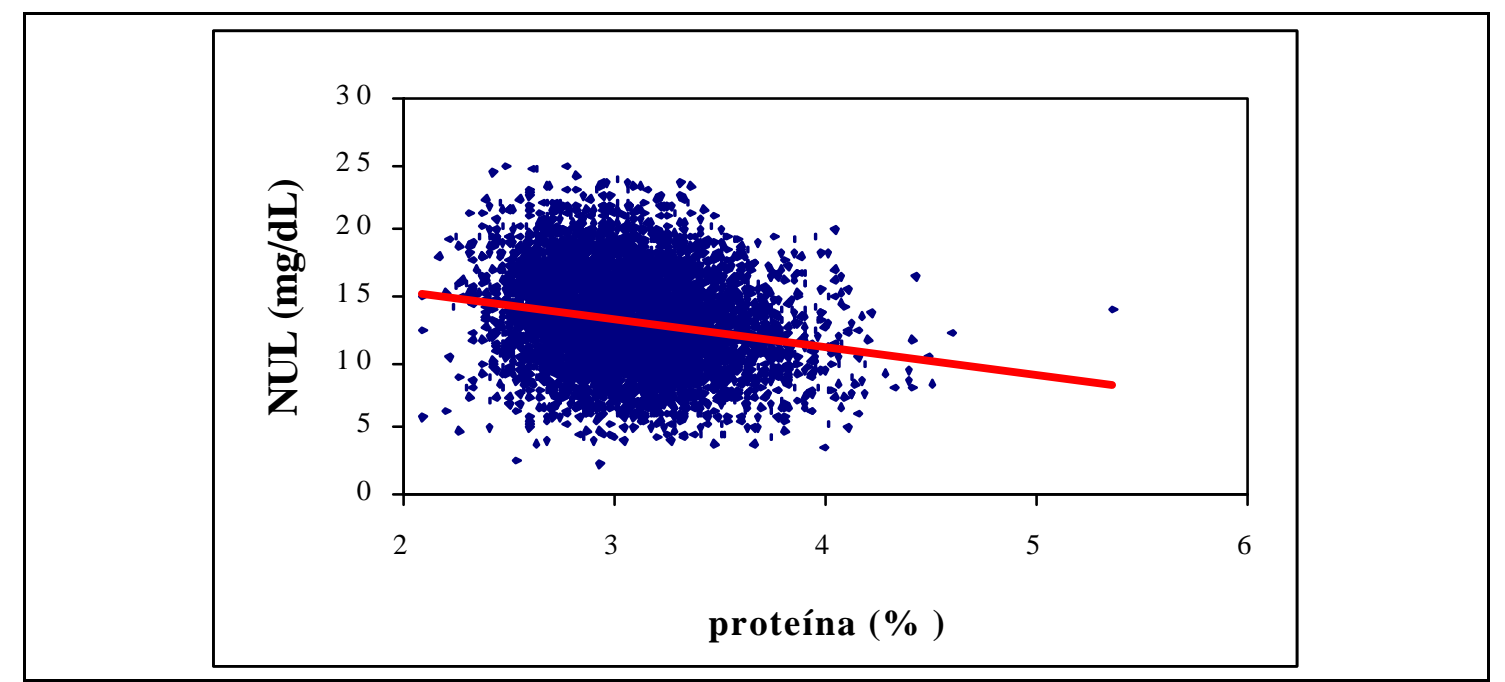

Figura 2 Efeito da percentagem de proteína sobre as concentrações de nitrogênio uréico no leite

Entretanto, Carlsson \& Perhson (1993) mostraram pequena relação entre a uréia no leite e as concentrações de proteína $(r=0,03)$ e gordura do leite $(r=0,06)$, utilizando, respectivamente, 1.709 e 1.724 amostras coletadas do tanque de expansão. Godden et al. (2001a) relataram associação negativa não-linear entre uréia no leite e as concentrações de gordura e proteína no leite, porém, numericamente muito pequena, pondo em questão a relevância biológica e econômica desse achado, segundo os autores. 
Jonker et al. (1999) simularam as concentrações-alvo de NUL e obtiveram média de NUL de 13,1 $\mathrm{mg} / \mathrm{dL}$ para uma vaca produzindo $10.000 \mathrm{~kg}$ de leite/lactação, 3,5\% de gordura do leite, 3,0\% de proteína do leite, $600 \mathrm{~kg}$ de peso corporal e estando na segunda lactação. Seus resultados mostraram que com o aumento ou diminuição de 0,5 unidade percentual na gordura do leite, a concentração estimada de NUL aumentou ou diminuiu, respectivamente, em 1,45 mg/dL. Porém, ao aumentar ou diminuir 0,3 unidade percentual na proteína do leite, a concentração estimada de NUL diminuiu ou aumentou, respectivamente, em 1,25 mg/dL, apontando que, ao aumentar a proteína do leite, a concentração de NUL diminui. Tal associação é explicada pelo fato que uma parte maior do nitrogênio ingerido é direcionado para a proteína do leite, diminuindo, assim, o NUL.

Arunvipas et al. (2002) relataram que, a cada aumento de 0,1 unidade percentual na proteína do leite, a concentração de NUL diminuiu em 0,2 mg/dL. Também observaram que baixas concentrações de NUL ocorreram em baixas e altas concentrações de gordura no leite. Porém, outros estudos não reportaram associação entre uréia no leite e percentagem de gordura e proteína verdadeira (Jaquette et al., 1986; Klusmeyer et al., 1990). Como, no presente estudo, não foram analisados os teores de proteína verdadeira no leite, comparações diretas não podem ser feitas com os trabalhos anteriores.

Dentre as produções dos componentes do leite, em $\mathrm{kg}$, observa-se pela Tabela 3 que a lactose e a proteína foram as que apresentaram os maiores coeficientes de determinação de, respectivamente, 0,6191 e 0,5562, sendo seguidas pela produção de sólidos totais e gordura, com $\mathrm{R}^{2}$ de 0,3680 e 0,2853 , respectivamente. Assim, nota-se que, dentre essas quatro variáveis, a produção de lactose e de proteína (kg) explicam 62 e 56\%, respectivamente, da variabilidade total de NUL. As inclinações das retas ("slopes"), para essas quatro variáveis, foram significativas $(\mathrm{P}<0,0001)$. Entretanto, houve falta de ajuste da equação linear para produção de gordura e proteína $(\mathrm{P}<0,01)$, enquanto que a equação linear apresentou um bom ajuste para produção de lactose $(\mathrm{P}=0,7590)$ e de sólidos totais $(\mathrm{P}=0,3238)$, revelando que a equação linear explica bem o efeito das produções de lactose e sólidos totais sobre as concentrações de NUL. Assim, 
observa-se que a cada aumento na produção de $1 \mathrm{~kg}$ de lactose ou de sólidos totais, há um aumento de 1,90 e $0,75 \mathrm{mg} / \mathrm{dL}$ de NUL, respectivamente.

Ao combinar as informações acima, observa-se que dentre a produção dos componentes do leite, a produção de lactose foi a que mais afetou NUL e mais explicou a variabilidade total desse. Mas é importante ressaltar que a produção de lactose foi também altamente correlacionada $(\mathrm{r}=0,9649)$ (discutido anteriormente) com a produção de leite (Tabela 2).

Entretanto, Godden et al. (2001b) não encontraram associação entre uréia média no leite do rebanho e produção de proteína média do rebanho $(\mathrm{kg})$, mas a associação foi positiva com a produção de gordura média do rebanho $(\mathrm{kg})$.

A contagem de células somáticas $(\mathrm{P}=0,0001)$ afetou as concentrações de NUL. A equação linear se ajustou bem para explicar os efeitos de LCCS sobre NUL $(\mathrm{P}=0,9000)$ e o coeficiente de determinação $\left(\mathrm{R}^{2}\right)$ foi de 0,1994 . Observa-se que, a cada aumento de uma unidade de LCCS, as concentrações de NUL diminuem em 0,29 $\mathrm{mg} / \mathrm{dL}$. Arunvipas et al. (2002) observaram que, a cada aumento de uma unidade no escore linear, a concentração de NUL diminui em $0,4 \mathrm{mg} / \mathrm{dL}$.

Wolfschoon-Pombo (1981) relatou que a mastite pode influenciar a concentração de uréia na amostra do quarto infectado da glândula mamária ao alterar a permeabilidade das membranas das células. Godden et al. (2001a) relataram uma associação negativa não-linear entre uréia no leite e o escore linear da contagem de células somáticas, mas relataram que tal associação pode não representar uma relação biológica entre esses dois parâmetros e pode, sim, ser um artefato do instrumento de calibração. Entretanto, no presente estudo, tal fato pode não ter ocorrido, pois a CCS encontrada não é considerada alta. Porém, Eicher et al. (1999) não observaram influência da contagem de células somáticas (medida, indiretamente, com o uso do CMT - "California Mastitis Test") sobre as concentrações de uréia no leite, nem mesmo quando as amostras foram coletadas de quartos diferentes.

Em uma discussão geral, Meyer et al. (2002) estudaram os efeitos de fatores não-nutricionais sobre NUL e obtiveram um modelo que incluía a produção de leite, proteína do leite, lactose, CCS, gordura do leite, dias em lactação e número de 
lactações, gerando um coeficiente de determinação $\left(\mathrm{R}^{2}\right)$ ajustado de 0,1271. Cabe discutir que tais autores utilizaram regressões múltiplas, usando o método Stepwise, que não permite a correção do $\mathrm{R}^{2}$, explicando, assim, o motivo desse valor ser tão baixo (como explanado anteriormente). Por isso, no presente estudo, foram realizadas regressões lineares, estudando-se, assim, os efeitos individuais das variáveis, mas permitindo o ajuste do coeficiente de determinação.

\subsection{Conclusões}

Dentre os fatores não-nutricionais, a produção de leite e a concentração de proteína do leite foram os fatores que mais afetaram as concentrações de nitrogênio uréico no leite, podendo auxiliar a utilização de NUL como indicador de avaliação nutricional de vacas em lactação. 


\section{MODELOS PARA ESTIMAR AS CONCENTRAÇÕES DE NITROGÊNIO URÉICO NO LEITE, EM FUNÇÃO DOS DIAS EM LACTAÇÃO, NÚMERO DE LACTAÇÕES E ÉPOCA DE PARIÇÃO DE VACAS HOLANDESAS}

\section{Resumo}

O objetivo do presente estudo foi desenvolver modelos para estimar as concentrações de nitrogênio uréico no leite (NUL), em função dos dias em lactação, número de lactações e época de parição, em condições de campo. Foram utilizadas 7.006 observações, provenientes de 855 vacas da raça Holandesa, pertencentes a um rebanho comercial do estado de São Paulo, referentes ao período compreendido entre setembro de 2000 e janeiro de 2002. Dados zootécnicos sobre produção de leite, número de dias em lactação e número de lactações foram coletados no dia da amostragem de leite. Amostras de leite foram coletadas mensalmente, na ordenha da manhã, para determinação da concentração de NUL. As épocas de parição foram divididas em verão (de novembro a abril) e inverno (de maio a outubro). Para estimar as concentrações de NUL, em função dos dias em lactação, foi utilizado o modelo proposto por Wood (1967), para descrever a curva de lactação das vacas, como segue: $y_{t}=A t^{b} e^{-c t_{i}}$, sendo: $y_{t}=$ concentração de nitrogênio uréico no dia $t$ em lactação; $A, b$ e $c=$ parâmetros da curva de lactação; $e=$ base dos logaritmos naturais. Posteriormente, foram acrescentados a esse modelo o efeito do número de lactações e a época de parição. Os modelos foram ajustados por quadrados mínimos. A concentração média de NUL foi de 13,3 mg/dL e a produção de leite média foi de $35,8 \mathrm{~kg} /$ dia. As concentrações de NUL apresentaram comportamento semelhante ao da curva de lactação, em função dos dias em lactação, e 
diferiram entre a primeira, segunda, terceira e quarta lactações, não diferindo entre a quarta e quinta lactações. O maior pico de NUL ocorreu na terceira lactação $(15,02$ $\mathrm{mg} / \mathrm{dL}$ ao $73^{\circ}$ dia em lactação), enquanto o pico de NUL das vacas primíparas (apesar de menor) ocorreu mais tardiamente, em relação às multíparas $\left(13,18 \mathrm{mg} / \mathrm{dL}\right.$ ao $113^{\circ}$ dia em lactação). Também foi observado que a época de parição influenciou as concentrações de NUL, dentro de cada número de lactação, não diferindo entre a 4 e $5^{\text {a }}$ lactações. As vacas paridas no verão iniciaram a lactação com maior concentração de NUL, aumentando pouco e gradativamente com o avanço da lactação, atingindo o pico bem mais tardiamente em relação às paridas no inverno e permanecendo assim, sem decrescer. Entretanto, para as vacas paridas no inverno, suas concentrações de NUL se assemelharam mais ao padrão convencional da curva de lactação.

\section{MODELS TO ESTIMATE MILK UREA NITROGEN CONCENTRATIONS, IN FUNCTION OF DAYS IN MILK, LACTATION NUMBER AND CALVING SEASON OF HOLSTEIN COWS}

\section{Summary}

The objective of this study was to develop models to estimate milk urea nitrogen concentrations (MUN), in function of days in milk, lactation number and calving season, for field conditions. In the study, 7,006 observations were used, coming from 855 Holstein cows, belonging to a commercial herd in Sao Paulo State (Brazil), from September/2000 to January/2002. Milk production (kg), days in milk (DIM) and lactation number (LN) were collected on the milk sampling days. Milk was sampled monthly for MUN analyses. Calving seasons (CS) were divided in summer (from November to April) and winter (from May to October). To estimate MUN concentrations, in function of DIM, a model, proposed by Wood (1967) to describe the lactation curve, was used, as shown: $y_{t}=A t^{b} e^{-c t_{i}}$, where: $y t=$ MUN concentration on 
day $t$ in milk; $A, b$ and $\mathrm{c}=$ parameters of lactation curve; $e=$ natural logarithm basis. Further, LN and CS were added to the model and the existence of coincidence was verified among curves. Models were adjusted by least square methodology. Mean MUN was $13.3 \mathrm{mg} / \mathrm{dL}$ and mean milk production was $35.8 \mathrm{~kg} /$ day. Concentrations of MUN showed similar pattern to the lactation curve, in function of DIM, and differed among $1^{\text {st }}, 2^{\text {nd }}, 3^{\text {d }}$ and $4^{\text {th }}$ lactations, not differing between $4^{\text {th }}$ and $5^{\text {th }}$ lactations. The highest peak of MUN occurred in the $3^{\text {d }}$ lactation $\left(15.0 \mathrm{mg} / \mathrm{dL}\right.$ on $73^{\text {rd }}$ day of lactation), while MUN peak of primiparous cows (in spite of being lower) occurred later $(13.2 \mathrm{mg} / \mathrm{dL}$ on $113^{\text {th }}$ day of lactation) in relation to multiparous. It was also observed that calving season influenced MUN concentrations inside of each LN, not differing between $4^{\text {th }}$ and $5^{\text {th }}$ lactations. Cows, which calved in the summertime, began lactation with higher MUN concentration, increasing little and gradually during lactation, reaching peak much later in relation to the ones that calved in the wintertime and remaining like that, with no decrease. However, MUN concentrations, for cows that calved in the wintertime, seemed more similar to the conventional pattern of lactation curve.

\subsection{Introdução}

A importância do suprimento adequado de nutrientes para vacas leiteiras, com a finalidade de manter elevada produção e adequada saúde, é bem reconhecida. Conseqüentemente, a perspectiva de encontrar parâmetros que poderiam ajudar em estimar a adequação da alimentação tem interesse prático. Um possível indicador é a uréia, uma vez que as concentrações de nitrogênio uréico no sangue de ruminantes são facilmente afetadas pelo consumo de proteína e energia na dieta (Lewis, 1957). Devido à forte relação entre nitrogênio uréico no sangue e no leite (Oltner \& Wiktorsson, 1983) e à rapidez nas análises para determinação de nitrogênio uréico no leite (NUL) (Oltner \& Sjaunja, 1982), as possibilidades para sua aplicação no campo devem ser consideradas. O leite tem a vantagem de ser obtido facilmente da vaca leiteira, evitando-se o estresse da coleta de sangue. 
Contudo, outros fatores, que não os nutricionais, têm sido revelados como capazes de afetar as concentrações de NUL. Entre eles estão: produção de leite (Oltner et al., 1985; Carlsson et al., 1995), idade da vaca (Carlsson et al., 1995), estágio de lactação (Carlsson et al., 1995), peso vivo (Oltner et al., 1985; Jonker et al., 1998). concentrações de proteína do leite (Jonker et al., 1999) e de gordura do leite (Jonker et al., 1998) e estação do ano (Carlsson \& Pehrson, 1993). Entretanto, antes de estender o uso de NUL como indicador da adequação nutricional de vacas leiteiras em condições nãoexperimentais, algumas condições devem ser levadas em consideração. Para tanto, esse estudo foi planejado para avaliar o comportamento de NUL em condições de campo, desenvolvendo modelos para estimar suas concentrações, em função dos dias em lactação, número de lactações e época de parição.

\subsection{Material e Métodos}

\subsubsection{Coleta de dados}

No estudo, foram utilizadas 7.006 observações, provenientes de 855 vacas da raça Holandesa, pertencentes ao rebanho da Fazenda Colorado, situada no município de Araras, estado de São Paulo. Essas observações foram coletadas no período compreendido entre setembro de 2000 e janeiro de 2002.

Os animais foram confinados em estábulo do tipo "free-stall", dotado de ventiladores e aspersores, acionados automaticamente quando a temperatura ultrapassava $23^{\circ} \mathrm{C}$. Após o parto, os animais foram ordenhados em sala do tipo "espinha de peixe", 2 x 12, linha baixa, com sistema de coleta de dados AFIMILK ${ }^{\circledR}$ - SAE AFIKIM, em que cada animal é identificado, bem como a sua produção de leite registrada diariamente. Os dados diários de produção de leite foram automaticamente lançados em um software de controle leiteiro para avaliação gerencial do rebanho.

Os animais foram alimentados 7 vezes ao dia, sendo o primeiro fornecimento às $5 \mathrm{~h}$ e o último, às $21 \mathrm{~h}$. Receberam dieta total e única, composta de 
silagem de milho, silagem pré-secada de gramínea, farelo de soja, gérmen de milho, silagem de grão úmido de milho, farelo de glúten de milho, polpa cítrica e mistura mineral, em que o volumoso correspondeu a $48 \%$ da dieta em MS. Para alimentação do rebanho, foi utilizado vagão de mistura total (TMR) de $10 \mathrm{~m}^{3}$, com desensilador e balança eletrônica. A composição estimada média da dieta foi 50,2\% de matéria seca (MS), 16,9\% de proteína bruta (\% MS), 4,5\% de extrato etéreo (\% MS), 18,6\% de fibra em detergente ácido (\% MS), 31,4\% de fibra em detergente neutro (\% MS), 40,2\% de carboidratos não-estruturais (\% MS), 6,6\% de matéria mineral (\% MS) e 1,75 Mcal/kg de energia líquida para lactação, sendo o consumo de matéria seca projetado de 23,0 $\mathrm{kg} / \mathrm{dia}$.

Das 8.844 observações coletadas, foram utilizadas 7.006, abrangendo vacas com 5 lactações ou menos, com até 305 dias em lactação e concentrações de nitrogênio uréico no leite inferiores a $25 \mathrm{mg} / \mathrm{dL}$. Dados zootécnicos sobre produção de leite $(\mathrm{kg})$, número de dias em lactação (DEL) e número de lactações (NL) foram coletados no dia da amostragem de leite. As épocas de parição foram divididas em verão (de novembro a abril) e inverno (de maio a outubro).

Amostras de leite foram coletadas mensalmente, sempre na ordenha da manhã, transferidas diretamente do medidor para os frascos de coleta $(60 \mathrm{~mL})$, cada um contendo duas pastilhas de bronopol (largo espectro) como conservante e homogeneizadas por, no mínimo, 15 segundos. Foram, então, encaminhadas para a Clínica do Leite do Departamento de Zootecnia da Escola Superior de Agricultura "Luiz de Queiroz"/ Universidade de São Paulo, para determinação das concentrações de nitrogênio uréico no leite (NUL) (mg/dL). Tal análise foi realizada utilizando-se $\mathrm{o}$ equipamento ChemSpeck 150®, por meio de método enzimático e espectrofotométrico de trans-reflectância (Bentley Instruments, 1998). 


\subsubsection{Análise estatística}

Para estimar as concentrações de NUL, em função dos dias em lactação, foi utilizado o modelo proposto por Wood (1967) para descrever a curva de lactação das vacas, como segue: $y_{t}=A t^{b} e^{-c t_{i}}$, sendo: $y_{t}=$ concentração de nitrogênio uréico $(\mathrm{mg} / \mathrm{dL})$ no dia $t$ em lactação; $A, b$ e $c=$ parâmetros da curva de lactação; $e=$ base dos logaritmos naturais. Posteriormente, foram acrescentados a esse modelo o efeito do número de lactações e época de parição, verificando-se a existência de coincidência entre as curvas para tais efeitos. O teste da razão de verossimilhança foi utilizado para verificar a significância do ajuste dos modelos e dos demais efeitos e, também, foi calculado o teste para falta de ajuste ("lack of fit"), conforme sugerido por Ratkowsky (1990), Neter et al. (1996) e Souza (1998). Os modelos foram ajustados por quadrados mínimos, sendo utilizado o procedimento NLIN do SAS (1999).

\subsection{Resultados e Discussão}

A concentração média de nitrogênio uréico no leite, encontrada neste estudo, foi de $13,3 \mathrm{mg} / \mathrm{dL}$ e a produção média de leite, de $35,8 \mathrm{~kg} / \mathrm{dia}$.

Para descrever a curva de NUL, em função dos dias em lactação, foi utilizado o modelo, proposto por Wood (1967), para descrever a curva de lactação das vacas. As estimativas dos parâmetros dessa curva estão apresentadas na Tabela 1. 
Tabela 1. Estimativas dos parâmetros da curva de Wood para as concentrações de NUL, erro-padrão da média e intervalo de confiança a 95\%

\begin{tabular}{cllll}
\hline Parâmetros & Estimativas & EPM & \multicolumn{2}{c}{ IC 95\% } \\
& & & \multicolumn{1}{c}{ LIC } & LSC \\
\hline A & 8,7237 & 0,3504 & 8,0367 & 9,4107 \\
b & 0,1409 & 0,0112 & 0,1189 & 0,1630 \\
c & 0,00169 & 0,000104 & 0,00149 & 0,00189
\end{tabular}

IC $95 \%$ = intervalo de confiança a $95 \%$; LIC = limite inferior de confiança; LSC $=$ limite superior de confiança; EPM = erro-padrão da média; $\mathrm{A}, \mathrm{b}, \mathrm{c}=$ parâmetros da curva.

Observa-se que a curva de nitrogênio uréico no leite, estimada pelo modelo de Wood, apresentou ajuste significativo para as concentrações de NUL $(\mathrm{P}<0,001)$ pelo teste da razão de verossimilhança e, além disso, o teste para falta de ajuste ("lack of fit") não foi significativo ( $\mathrm{P}=0,0576)$. O pico de NUL foi de 14,13 $\mathrm{mg} / \mathrm{dL}$, ocorrendo no $83^{\circ}$ dia de lactação. A curva de NUL, ajustada para o modelo de Wood, está ilustrada na Figura 1.

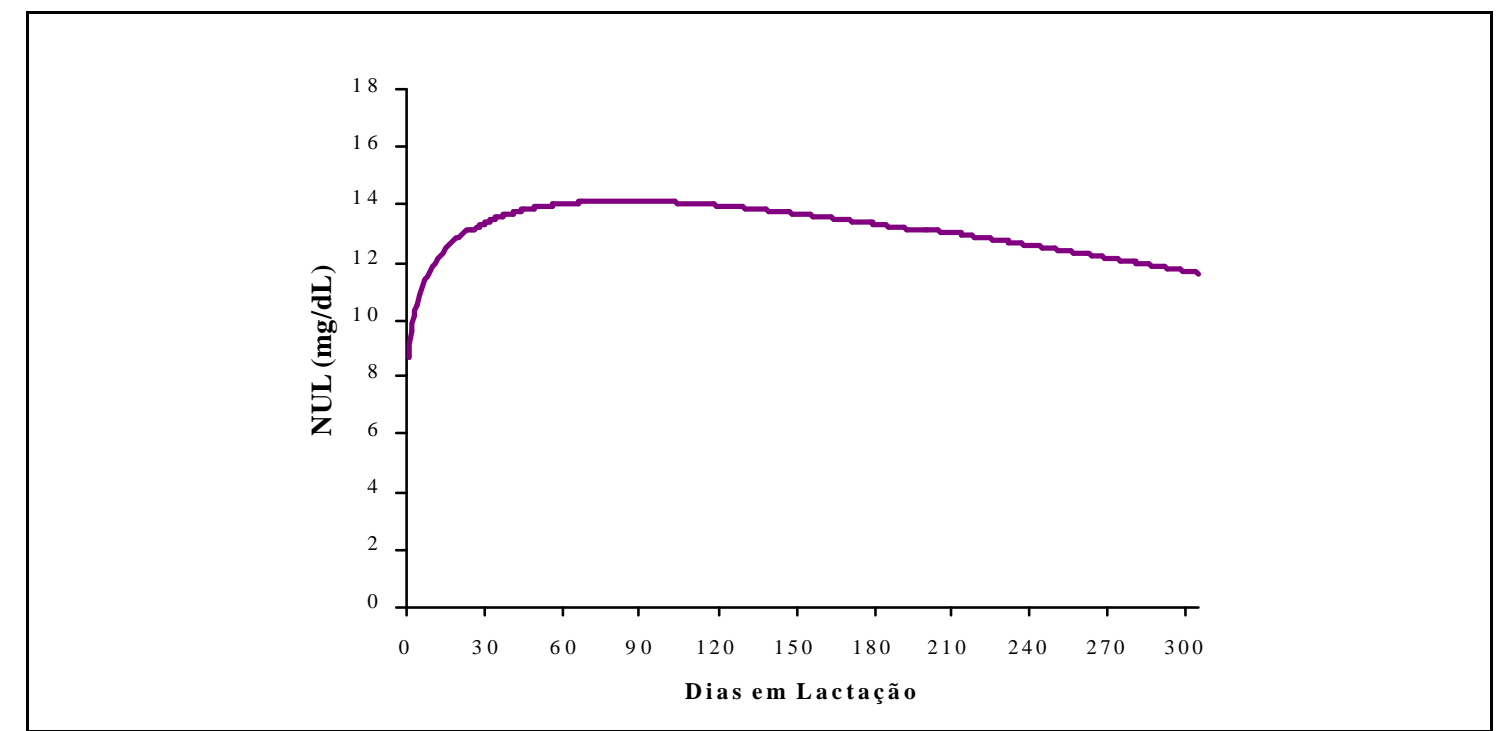

Figura 1- Curva de nitrogênio uréico no eite, segundo o modelo proposto por Wood (1967)

Nota-se que, sem considerar outras variáveis que podem influenciar as concentrações de NUL dos animais, como é o caso do número de lactações, o ajuste do modelo de Wood é significativo, apesar de baixo ( $\mathrm{P}=0,0576)$, e seu coeficiente de determinação $\left(R^{2}\right)$ foi de 0,0446 . Numa primeira observação, o $R^{2}$ pode parecer baixo; 
contudo, há de se considerar que existem repetições dos dias em lactação e, portanto, o modelo só pode explicar o ponto médio de NUL para cada dia em lactação. Mesmo assim, parece razoável uma única variável poder explicar 4,5\% das 7.006 observações de nitrogênio uréico no leite, dado que existem inúmeros fatores não-controlados, principalmente os nutricionais, que podem influenciar a concentração de NUL.

Em concordância com vários outros trabalhos (Bruckental et al., 1980; Gustafsson et al., 1987; Emanuelson et al., 1993; Carlsson et al., 1995), a concentração de NUL foi menor no início de lactação, considerando todos os números de lactações. Alguns fatores podem exercer efeitos para reduzir a concentração de uréia no início da lactação (Carlsson et al., 1995). Entre eles, estão a inabilidade das vacas em ingerir alimento suficiente no início da lactação, o que pode induzir - ou ser o resultado de uma função subótima da microbiota ruminal e o risco de distúrbios metabólicos durante o primeiro mês de lactação.

É interessante notar que Oldham (1984) discutiu a possibilidade de um mecanismo de conservação de nitrogênio no início da lactação. Contraditoriamente, a proposta de Kaufmann (1982) é que, nesse período, deveria se esperar alta concentração de NUL, em virtude da dificuldade que as vacas de alta produção têm de satisfazer suas exigências energéticas, levando à utilização de proteína corporal.

Godden et al. (2001a) relataram associação positiva, mas não-linear, entre uréia no leite e DEL, em que as concentrações de NUL foram mais baixas nos primeiros 60 dias, aumentando entre 60 e 150 e decrescendo após 150 dias em lactação. Por sua vez, os resultados de Carlsson et al. (1995) mostraram que, quando as vacas foram confinadas, a concentração média de uréia no leite decresceu durante os últimos 4 a 5 meses de lactação. A possível explicação dada pelos autores foi de que, na Suécia, recomenda-se fornecer dieta com relação energia/proteína mais alta no final da lactação do que nos estágios mais iniciais.

Como, no presente experimento, todos animais receberam a mesma dieta em todas as fases da lactação, nota-se que as concentrações de NUL se comportam de acordo com a curva de Wood (pico no $83^{\circ}$ dia de lactação). Considerando os resultados do estudo anterior da presente tese, em que a concentração de NUL está linearmente 
associada com a produção de leite, sugere-se que aquela segue o mesmo padrão da produção de leite, uma vez que a curva de Wood é uma das curvas utilizadas para descrever a lactação de vacas. Jonker et al. (1998) observaram que o pico das concentrações de NUL ocorreu no $63^{\circ}$ dia de lactação, enquanto o pico de produção de leite ocorreu no $35^{\circ}$ dia.

Para verificar a existência do efeito do número de lactações, construiu-se um modelo em que foram estimados os parâmetros da curva de Wood para cada um dos 5 números de lactação ao mesmo tempo. Procedeu-se, então, ao teste da razão de verossimilhança para comparar o modelo que continha uma única curva para todos os números de lactação com aquele com uma curva para cada número de lactação. $\mathrm{O}$ teste indicou que existe efeito de número de lactação $(\mathrm{P}<0,0001)$ na curva considerada, ou seja, pelo menos duas curvas de lactação diferem entre si.

No entanto, pela observação das estimativas dos parâmetros (Tabela 2), notou-se que para as lactações $4^{\mathrm{a}}$ e $5^{\mathrm{a}}$, as estimativas foram parecidas, sendo, então, testada a coincidência entre as curvas nesses dois números de lactação. Pelo teste da razão de verossimilhança, observou-se coincidência entre as curvas na $4^{\mathrm{a}}$ e na $5^{\mathrm{a}}$ lactação $(\mathrm{P}=0,6216)$. Testou-se, também, a coincidência entre as curvas nos números de lactação de 3 a 5, porém, o teste acusou diferenças $(\mathrm{P}<0,0108)$ entre, pelo menos, dois dos 3 números de lactação no modelo estudado. Em seguida, foi testada a coincidência entre as curvas na $2^{\mathrm{a}}$ e $3^{\mathrm{a}}$ lactação, observando-se que elas diferem entre si $(\mathrm{P}<0,0002)$. 
Tabela 2. Estimativas dos parâmetros da curva de Wood com efeito do número de lactações, erro-padrão da média e intervalo de confiança a $95 \%$

\begin{tabular}{lccllc}
\hline NL & Parâmetros & Estimativas & EPM & \multicolumn{2}{c}{ IC 95\% } \\
& & & & LIC & LSC \\
\hline 1 & A & 6,5016 & 0,4868 & 5,5474 & 7,4558 \\
& b & 0,1894 & 0,0207 & 0,1490 & 0,2299 \\
& c & 0,00167 & 0,000182 & 0,00131 & 0,00202 \\
2 & A & 10,0729 & 0,7385 & 8,6252 & 11,5206 \\
& b & 0,1258 & 0,0206 & 0,0854 & 0,1662 \\
& c & 0,00199 & 0,000191 & 0,00161 & 0,00236 \\
3 & A & 10,2769 & 0,8413 & 8,6277 & 11,9262 \\
& b & 0,1152 & 0,0233 & 0,0696 & 0,1609 \\
& c & 0,00157 & 0,000225 & 0,00113 & 0,00201 \\
4 e 5 & A & 9,5388 & 0,7945 & 7,9813 & 11,0962 \\
& b & 0,1234 & 0,0235 & 0,0774 & 0,1695 \\
& c & 0,00158 & 0,000224 & 0,00114 & 0,00202 \\
\hline
\end{tabular}

IC 95\% = intervalo de confiança a 95\%; NL = número de lactações; LIC = limite inferior de confiança; LSC = limite superior de confiança; EPM = erro -padrão da média; A, b, c = parâmetros da curva.

Portanto, pode-se afirmar que não existe diferença entre as curvas na quarta e na quinta lactação, isto é, necessita-se estimar apenas quatro curvas dos cinco números de lactação estudados (Figura 2). $O$ coeficiente de determinação $\left(R^{2}\right)$ do modelo de Wood para as $1^{\mathrm{a}}, 2^{\mathrm{a}}, 3^{\mathrm{a}}, 4^{\mathrm{a}}-5^{\mathrm{a}}$ lactações foi de 0,0878 . $O \mathrm{R}^{2}$ para a curva de NUL ajustada, em função dos números de lactação, foi superior ao $R^{2}$ do modelo que não foi ajustado. Cabe ressaltar que esse valor pode parecer baixo; contudo, há de se considerar que existem repetições dos dias em lactação e, assim, o modelo só pode explicar o ponto médio de NUL para cada dia em lactação. Desse modo, o modelo ajustado para os efeitos dos números de lactações melhor explicou as variações nas concentrações de NUL em relação ao não-ajustado. Os picos de concentração de NUL encontrados para as primeira, segunda, terceira e quarta/quinta lactações foram 13,18, 14,96, 15,02 e 14,44 mg/dL, respectivamente, nos $113^{\circ}, 63^{\circ}, 73^{\circ}$ e $78^{\circ}$ dias de lactação. 


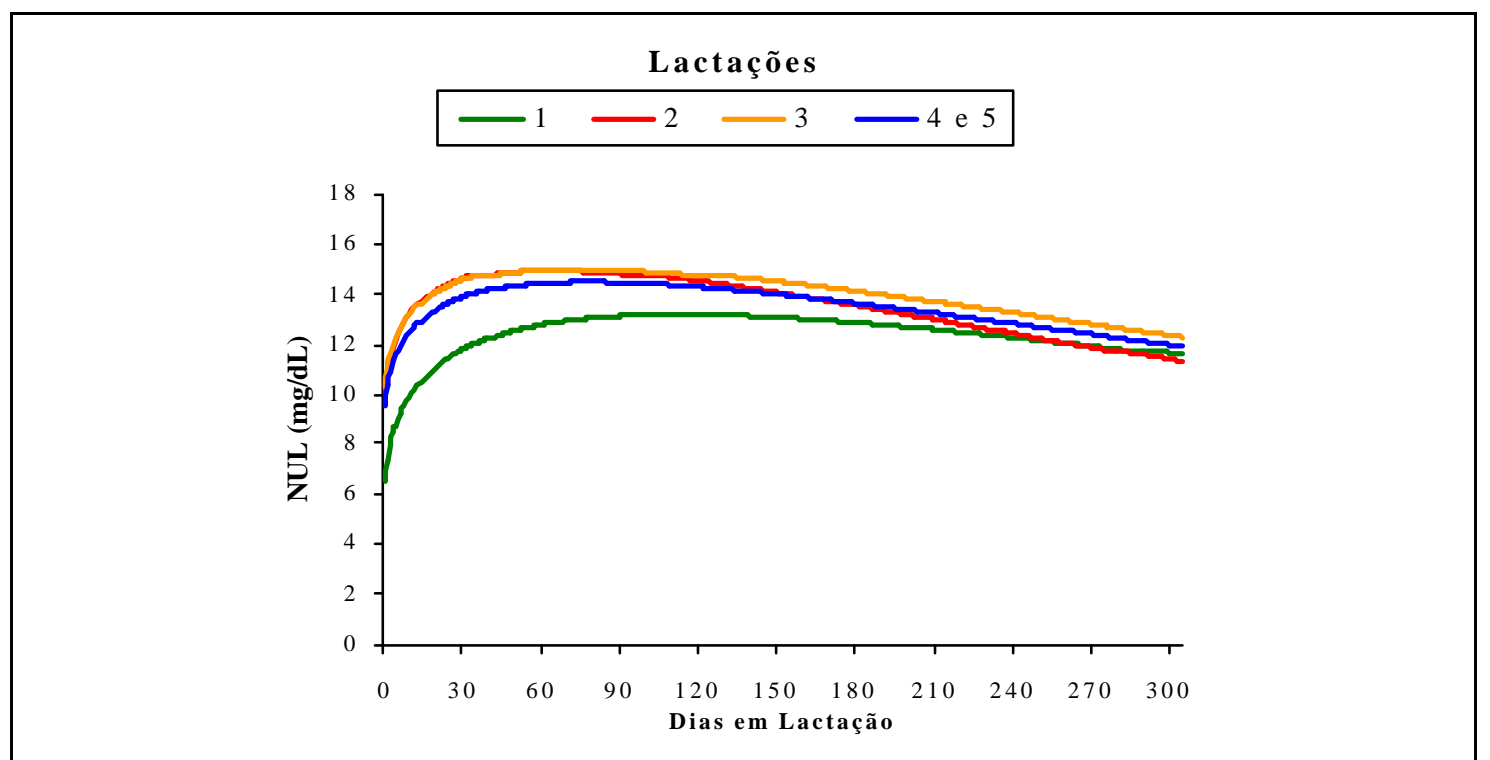

Figura 2- Curvas de nitrogênio uréico no leite ajustadas para efeito do número de lactações

Esses resultados concordam com os de Canfield et al. (1990) e Oltner et al. (1995), que explicitaram a importância de se considerar o número de lactações, pois vacas primíparas tiveram menor concentração de NUL do que as multíparas. Godden et al. (2001a) relataram interação entre número de lactações e dias em lactação, de modo que a taxa de declínio da uréia no leite do meio para o fim da lactação foi maior em animais com mais de duas lactações. Contudo, Schepers \& Meijer (1998) não encontraram interação entre número de lactações e dias em lactação, quando experimentos foram controlados para os fatores nutricionais. Eles sugerem que os fatores não-nutricionais são de menor importância para explicar a associação entre uréia no leite e número de lactações e/ou dias em lactação.

Entretanto, Jonker et al. (1998) observaram que vacas de primeira lactação apresentaram maiores concentrações estimadas de NUL, em relação às vacas multíparas, ou seja, cada mudança no número de lactações representou uma mudança estimada em 0,45 mg/dL nas concentrações médias de NUL. Esses autores relataram que, em geral, o aumento nas exigências de nitrogênio aumentou a concentração média estimada de NUL. Porém, Carlsson et al. (1985) não reportaram diferenças na concentração de uréia no leite entre vacas primíparas e multíparas. 
Outro fator a ser considerado, e que pode afetar a concentração de NUL dos animais, é a época de parição. Desse modo, foram inseridos mais parâmetros no modelo de Wood proposto, com o intuito de verificar se existiu efeito da época de parição (verão e inverno) sobre as curvas de lactação das vacas, isto é, se seria necessário construir uma curva de lactação para cada época de parição dentro dos números de lactação $\left(1^{\mathrm{a}}, 2^{\mathrm{a}}, 3^{\mathrm{a}}\right.$ e $\left.4^{\mathrm{a}}-5^{\mathrm{a}}\right)$. Sendo assim, esse modelo tem o dobro de parâmetros em relação àquele com os números de lactação apenas, pois foi estimada uma curva para cada combinação de época de parição com número de lactações. O teste da razão de máxima verossimilhança acusou diferenças significativas $(\mathrm{P}<0,0001)$ entre as épocas de parição em, pelo menos, um dos números de lactação, ou seja, as curvas ajustadas para época de parição não são coincidentes.

No entanto, pela observação das estimativas dos parâmetros (Tabela 3), notou-se que as curvas foram parecidas para a quarta e a quinta lactação, considerando as épocas de parição. Então, foi testada a coincidência entre as curvas, ajustadas para as épocas de parição, nesses dois números de lactações (4 e 5), indicando que continua existindo coincidência $(\mathrm{P}=0,1390)$ entre tais curvas. Testou-se, também, a coincidência entre as curvas nos números de lactação de 3 a 5 , considerando as épocas de parição. Porém, o teste acusou diferenças significativas $(\mathrm{P}<0,0057)$ entre, pelo menos, dois dos 3 números de lactação no modelo estudado. 
Tabela 3. Estimativas dos parâmetros da curva de Wood com efeitos do número de lactações e época de parição, erro-padrão da média e intervalo de confiança a $95 \%$

\begin{tabular}{|c|c|c|c|c|c|c|}
\hline \multirow[t]{2}{*}{$\mathbf{N L}$} & \multirow[t]{2}{*}{ Epoca } & \multirow[t]{2}{*}{ Parâmetros } & \multirow[t]{2}{*}{ Estimativas } & \multirow[t]{2}{*}{ EPM } & \multicolumn{2}{|c|}{ IC95\% } \\
\hline & & & & & LIC & LSC \\
\hline \multirow[t]{3}{*}{1} & verão & $\bar{A}$ & 5,6804 & 0,6892 & 4,3293 & 7,0314 \\
\hline & verão & $\mathrm{b}$ & 0,1957 & 0,0327 & 0,1316 & 0,2598 \\
\hline & verão & $\mathrm{c}$ & 0,000967 & 0,000264 & 0,000449 & 0,00149 \\
\hline \multirow[t]{3}{*}{2} & verão & A & 8,7931 & 1,1475 & 6,5436 & 11,0426 \\
\hline & verão & b & 0,1210 & 0,0357 & 0,0511 & 0,1909 \\
\hline & verão & $\mathrm{c}$ & 0,00114 & 0,000300 & 0,000557 & 0,00173 \\
\hline \multirow[t]{3}{*}{3} & verão & A & 12,5262 & 1,5453 & 9,4968 & 15,5555 \\
\hline & verão & b & 0,0239 & 0,0350 & $-0,0448$ & 0,0926 \\
\hline & verão & $\mathrm{c}$ & 0,000104 & 0,000326 & $-0,00053$ & 0,000743 \\
\hline \multirow[t]{3}{*}{4 e 5} & verão & A & 11,9115 & 1,2323 & 9,4957 & 14,3273 \\
\hline & verão & $\mathrm{b}$ & 0,0378 & 0,0295 & $-0,0200$ & 0,0955 \\
\hline & verão & $\mathrm{c}$ & 0,000310 & 0,000287 & $-0,00025$ & 0,000872 \\
\hline \multirow[t]{3}{*}{1} & inverno & A & 5,6722 & 0,5381 & 4,6173 & 6,7271 \\
\hline & inverno & b & 0,2591 & 0,0267 & 0,2067 & 0,3115 \\
\hline & inverno & $\mathrm{c}$ & 0,00318 & 0,000258 & 0,00267 & 0,00368 \\
\hline \multirow[t]{3}{*}{2} & inverno & A & 9,4467 & 0,8226 & 7,8342 & 11,0593 \\
\hline & inverno & $\mathrm{b}$ & 0,1736 & 0,0250 & 0,1246 & 0,2225 \\
\hline & inverno & $\mathrm{c}$ & 0,00308 & 0,000254 & 0,00258 & 0,00357 \\
\hline \multirow[t]{3}{*}{3} & inverno & A & 8,3093 & 0,8906 & 6,5634 & 10,0552 \\
\hline & inverno & $\mathrm{b}$ & 0,2014 & 0,0307 & 0,1412 & 0,2616 \\
\hline & inverno & $\mathrm{c}$ & 0,00298 & 0,000314 & 0,00236 & 0,00359 \\
\hline \multirow[t]{3}{*}{4 e 5} & inverno & A & 6,7479 & 0,8403 & 5,1006 & 8,3952 \\
\hline & inverno & b & 0,2400 & 0,0350 & 0,1713 & 0,3086 \\
\hline & inverno & $\mathrm{c}$ & 0,00313 & 0,000338 & 0,00246 & 0,00379 \\
\hline
\end{tabular}

IC 95\% = intervalo de confiança a 95\%; época = época de parição; $\mathrm{NL}=$ número de lactações; LIC $=$ limite inferior de confiança; LSC = limite superior de confiança; EPM = erro-padrão da média; $\mathrm{A}, \mathrm{b}, \mathrm{c}=$ parâmetros da curva.

Portanto, pode-se afirmar que não existe diferença entre as curvas na quarta e na quinta lactação, ajustadas para a época de parição, isto é, necessita-se estimar apenas oito curvas das dez possíveis (Figura 3). O R ${ }^{2}$ do modelo de Wood para as curvas de NUL, ajustadas pela época de parição, dentro das lactações $1^{\mathrm{a}}, 2^{\mathrm{a}}, 3^{\mathrm{a}}$ e $4^{\mathrm{a}}-5^{\mathrm{a}}$, aumentou para 0,1411 , em relação às curvas ajustadas para apenas $1^{\mathrm{a}}, 2^{\mathrm{a}}, 3^{\mathrm{a}}$ e $4^{\mathrm{a}}-5^{\mathrm{a}}$ 
lactações. Esse valor ainda parece baixo, contudo há de se considerar que existem repetições dos dias em lactação e, assim, o modelo só pode explicar o ponto médio de NUL para cada dia em lactação. Entretanto, esse modelo, ajustado para o efeito da época de parição, se apresenta melhor que o anterior.

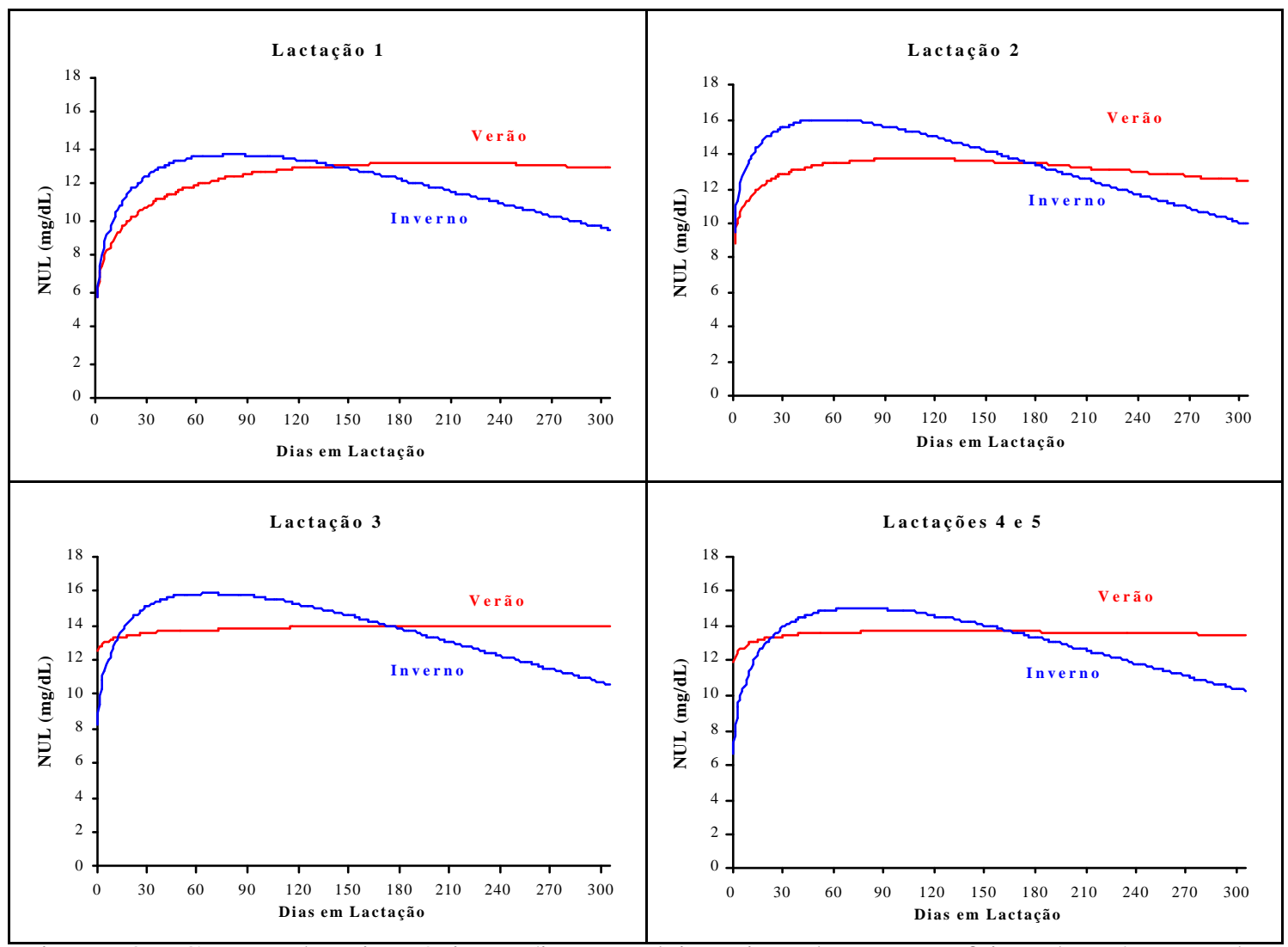

Figura 3- Curvas de nitrogênio uréico no leite ajustadas para efeito das épocas de parição dentro de cada número de lactação

Observa-se que, para vacas de primeira lactação que pariram no verão, o pico de NUL ocorreu aos 202 dias de lactação e foi de 13,20 mg/dL, enquanto para as que pariram no inverno, foi de 13,69 mg/dL aos 81 dias de lactação. Para vacas de segunda lactação, paridas no verão, o pico de NUL $(13,70 \mathrm{mg} / \mathrm{dL})$ ocorreu no $106^{\circ}$ dia e, para as vacas paridas no inverno, o pico ocorreu mais cedo, no $56^{\circ}$ dia, apresentando maior concentração $(15,99 \mathrm{mg} / \mathrm{dL})$. As vacas de terceira lactação, que pariram no verão, apresentaram pico de NUL de 13,92 mg/dL aos 230 dias de lactação, enquanto as 
paridas no inverno apresentaram maior pico $(15,87 \mathrm{mg} / \mathrm{dL}$ ) e mais antecipado (aos 68 dias de lactação). As vacas na $4^{\mathrm{a}}$ e $5^{\mathrm{a}}$ hctações, como suas curvas foram coincidentes, apresentaram pico de NUL de $13,75 \mathrm{mg} / \mathrm{dL}$ no $122^{\circ}$ dia em lactação, quando paridas no verão, e de $15,04 \mathrm{mg} / \mathrm{dL}$ ao $77^{\circ}$ dia em lactação, quando paridas no inverno.

Pelos resultados apresentados acima, pode-se inferir que as vacas paridas no inverno, sem considerar o número de lactações, apresentaram pico de concentração de NUL bem mais cedo na lactação do que as paridas no verão. Pela Figura 3, observase que, para as vacas que pariram no inverno, suas concentrações de NUL se assemelharam mais ao padrão convencional da curva de lactação, com ascensão até o pico e, a partir daí, com suave declínio até o fim da lactação, não importando o número de lactações.

Uma possível razão para tal observação é que as vacas paridas no inverno aumentam seu consumo gradativamente, no início da lactação, como se é esperado (NRC, 1989), estando nessa fase ingerindo menos do que sua exigência para produção de leite. Ao atingir o pico de lactação, sua concentração de NUL começa a declinar, provavelmente concomitante à produção de leite (de acordo com sua persistência de lactação), acrescendo, ainda, o fato de que nessa fase, as vacas estão no período do verão, quando a ingestão de matéria é ainda menor.

Porém, as vacas paridas no verão, começaram a lactação com maior ou igual concentração de NUL, aumentando pouco e gradativamente com o aumento nos dias em lactação, atingindo o pico bem mais tardiamente em relação às paridas no inverno e permanecendo assim, sem decrescer. Talvez, a razão para isso seja que, ao parirem no verão, além de apresentarem menor ingestão de matéria seca no início da lactação, ainda estão sofrendo de estresse térmico, o que diminuiu ainda mais sua produção. Assim, mesmo com baixa ingestão de matéria seca, a produção não é alta, sobrando, então, mais proteína em relação à energia ingerida para ser transformada em uréia.

Pode-se sugerir, ainda, que o não-decréscimo da concentração de NUL, à medida que aumenta o número de dias em lactação, seja devido ao fato de que o término da lactação dessas vacas coincide com o inverno. Nessa época, os animais aumentam a 
ingestão de matéria seca, em relação ao verão, apesar de a produção estar declinando, sobrando, assim, proteína ingerida para ser transformada em uréia. Entretanto, cabe lembrar que não há dados de consumo dos animais no presente estudo para confirmar tais suposições.

Carlsson et al. (1995) investigaram a estação do ano sobre as concentrações de uréia no leite, comparando os resultados obtidos quando as vacas estavam confinadas com os resultados obtidos quando as vacas estavam pastejando. Eles observaram que o formato das curvas foi mais regular quando as vacas estavam confinadas e as concentrações de uréia foram maiores no pico de lactação do que mais tardiamente durante a lactação. Durante a estação de pastejo, o padrão de concentração de uréia, nas primíparas, foi diferente, com aumento entre o $9^{\circ}$ e o $11^{\circ}$ mês da lactação. Quando confinadas, as vacas multíparas apresentaram maior concentração de uréia do que as primíparas, mas, durante a estação de pastejo, não foram observadas diferenças entre os números de lactações.

Por sua vez, Godden et al. (2001a) observaram que a concentração de uréia no leite foi maior no verão (julho a setembro) com vacas confinadas no Canadá. Tais autores sugeriram que a associação entre uréia no leite e estação do ano pode estar confundida com estágio de lactação e efeitos nutricionais. Arunvipas et al. (2002) também reportaram elevadas concentrações de NUL no final do inverno/início de verão (março e abril) no Canadá, com os maiores valores ocorrendo em julho e agosto (13,10 $\mathrm{mg} / \mathrm{dL})$.

\subsection{Conclusões}

As concentrações de nitrogênio uréico no leite apresentaram comportamento semelhante à curva de lactação, em função dos dias em lactação, diferindo entre as $1^{\mathrm{a}}, 2^{\mathrm{a}}, 3^{\mathrm{a}}$ e $4^{\mathrm{a}}-5^{\mathrm{a}}$ lactações, sendo influenciadas pela época de parição. 


\section{VALIDAÇÃO DE MODELOS DE PREDIÇÃO DAS CONCENTRAÇÕES DE NITROGÊNIO URÉICO NO LEITE DE VACAS LEITEIRAS}

\section{Resumo}

O objetivo do presente trabalho foi validar modelos de predição de nitrogênio uréico no leite (NUL), desenvolvidos a partir de dados experimentais americanos, para as condições de campo brasileiras, visando contribuir para avaliação da adequação nutricional de dietas de vacas leiteiras e predição da excreção de nitrogênio para o ambiente. Foram utilizadas 8.833 observações, provenientes de 855 vacas da raça Holandesa, de um rebanho comercial do estado de São Paulo, entre setembro de 2000 e janeiro de 2002. A produção de leite, o peso vivo, o número de dias em lactação e o número de lactações foram coletados no dia da amostragem do leite. Amostras de leite foram coletadas mensalmente, na ordenha da manhã, para determinação da gordura, proteína, lactose, sólidos totais, NUL e contagem de células somáticas. Os três modelos estudados são derivados de um modelo para predição de nitrogênio urinário (NU) (Jonker et al., 1998). O modelo 1 de predição de NUL (NU/ 12,54) foi desenvolvido por Jonker et al. (1998). Os modelos 2 (NU/17,6) e 3 (NU/(0,0259 x PV)) foram desenvolvidos por Kauffman \& St-Pierre (2001). Para a avaliação dos 3 modelos, foram medidas a acurácia, a precisão e a robustez. Ao usar o consumo de matéria seca (CMS) individual, estimado pelo NRC (2001), observa-se que o modelo 2, apesar de mais acurado (viés=0,94 $\mathrm{mg} / \mathrm{dL}$ ), foi menos preciso (erro residual=4,50 $\mathrm{mg} / \mathrm{dL}$ ) que o modelo 3 (viés $=1,41$ e erro residual $=4,11 \mathrm{mg} / \mathrm{dL}$ ), enquanto o modelo 1 foi o menos acurado (viés=6,94 $\mathrm{mg} / \mathrm{dL}$ ) e o menos preciso (erro residual=5,40 mg/dL). Os 3 modelos não se 
apresentaram robustos, pois foram influenciados por quase todas as variáveis estudadas. Ao utilizar o consumo real médio mensal do rebanho para estimar o CMS individual, observa-se que o modelo 3, apesar de mais acurado (viés=-0,21 $\mathrm{mg} / \mathrm{dL}$ ), foi menos preciso (erro residual=5,24 $\mathrm{mg} / \mathrm{dL}$ ) que o modelo 2 (viés=-1,72 e erro residual=4,90 $\mathrm{mg} / \mathrm{dL}$ ), enquanto o modelo 1 foi o menos acurado (viés=2,93 mg/dL) e o menos preciso (erro residual=5,99 mg/dL). Houve falta de robustez para os 3 modelos, pois foram afetados por quase todas as variáveis estudadas. A produção de leite foi a variável que mais explicou as variações nos modelos nesse estudo, podendo, assim, ser neles incluída. Ao usar o consumo real médio mensal de MS do rebanho para estimar NUL médio do rebanho, nota-se falta de acurácia para os modelos 1 (viés=2,60 mg/dL) e 2 (viés=-1,95 mg/dL), enquanto o modelo 3 foi acurado $(-0,89 \mathrm{mg} / \mathrm{dL}$ ). Contudo, os modelos 1, 2 e 3 não diferiram entre si quanto à precisão (erro residual=3,72, 2,68 e 2,64 $\mathrm{mg} / \mathrm{dL}$, respectivamente). Os modelos 1 e 2 não apresentaram robustez para o número de dias em lactação, tampouco o modelo 1 para a concentração de gordura. Considerando os três métodos de se estimar o consumo de MS, conclui-se que os três modelos de predição de NUL diferem entre si quanto à acurácia, precisão e robustez, apresentando uso questionável quando o objetivo for predizer NUL para vacas leiteiras ou predizer a excreção de nitrogênio urinário nas condições de campo estudadas.

\section{VALIDATION OF MODELS FOR PREDICTING MILK UREA NITROGEN CONCENTRATIONS}

\section{Summary}

The objective of this study was to validate prediction models for milk urea nitrogen (MUN), developed from American experimental database, using Brazilian field conditions, aiming to evaluate utilization efficiency of diets for dairy cows and to predict nitrogen excretion to the environment. It was used 8,833 observations, coming 
from 855 Holstein cows, belonging to a commercial herd in Sao Paulo State (Brazil), from September/2000 to January/2002. Milk production, body weight, days in milk and lactation number were collected on the milk sampling days. Milk was sampled monthly, during morning milking, for analyses of fat, protein, lactose and total solids, milk urea nitrogen and somatic cells count. The three models studied are derived from a first one to predict urinary nitrogen (UN) (Jonker et al., 1998). Model 1 for predicting MUN (UN/12.54) was developed by Jonker et al. (1998). Models 2 (UN/17.6) and 3 (UN/(0.0259 x BW)) were developed by Kauffman \& St-Pierre (2001), where this last one was adjusted for body weight (BW) effect. To evaluate models, accuracy, precision and robustness of those three models were tested. By using individual dry matter intake (DMI), estimated by NRC (2001), it was observed that model 2, despite being more accurate (mean bias=0.94 mg/dL), was less precise (residual error=4.50 mg/dL) than model 3 (mean bias $=1.41$ and residual error $=4.11 \mathrm{mg} / \mathrm{dL}$ ), while model 1 was the least accurate (mean bias=6.94 $\mathrm{mg} / \mathrm{dL}$ ) and the least precise (residual error=5.40 mg/dL). The three models were not robust, because were influenced by almost all the variables studied. By using mean monthly DMI of the herd to estimate individual DMI, it was observed that model 3 , despite more accurate (mean bias $=-0.21 \mathrm{mg} / \mathrm{dL}$ ), was less precise (residual error=5.24 mg/dL) than model 2 (mean bias=-1.72 and residual error=4.90 $\mathrm{mg} / \mathrm{dL}$ ), while model 1 was the least accurate (mean bias=2.93 $\mathrm{mg} / \mathrm{dL}$ ) and the least precise (residual error=5.99 $\mathrm{mg} / \mathrm{dL}$ ). There was lack of robustness for the three models, being influenced by almost all variables studied. Milk production showed the highest $\mathrm{R}^{2}$, indicating that this variable most explains the models variations and should be included in them. By using real mean DMI of the herd to estimate mean herd MUN, lack of accuracy was found for models 1 (mean bias=2.60 mg/dL) and 2 (mean bias=-1.95 $\mathrm{mg} / \mathrm{dL}$ ), while model 3 was accurate (mean bias $=-0.89 \mathrm{mg} / \mathrm{dL}$ ). However, precision among models 1, 2 and 3 did not differ (residual error=3.72, 2.68 and $2.64 \mathrm{mg} / \mathrm{dL}$, respectively). Models 1 and 2 did not show robustness for days in milk, nor model 1 for fat percentage. Considering those three methods to estimate DMI, it is concluded that the three models for predicting MUN differ among themselves relating to accuracy, precision and robustness, presenting questionable use when the objective is to predict 
MUN of dairy cows or to predict urinary nitrogen excretion in the field conditions studied.

\subsection{Introdução}

A concentração de nitrogênio uréico no leite (NUL) vem se apresentando uma ferramenta útil para avaliar se um rebanho de vacas (ou mesmo as vacas individualmente) está sendo alimentado com quantidades ótimas de proteína, se a relação entre proteína degradável e não-degradável na dieta está ideal ou, ainda, se o balanço entre o consumo de proteína e energia pelas vacas está adequado (Carlsson \& Pehrson, 1994).

De acordo com Atner et al. (1985), não é possível estimar com certeza, a partir de uma única determinação de uréia, o "status" nutricional de uma vaca. Mas quando as concentrações médias de uréia no leite são determinadas em grupos de animais ou em rebanhos, inferências diretas, com relação à adequação da alimentação, parecem ser possíveis. Contudo, é improvável que uma concentração específica de uréia no leite possa ser definida para que seja válida durante todos os estágios de lactação e sob todas as condições de alimentação e manejo. Fatores como a relação entre a capacidade de consumo de alimento e o potencial de produção de leite, o custo dos alimentos disponíveis e seu efeito geral sobre a saúde e fertilidade das vacas, afetarão, obviamente, a decisão de qual é a concentração de uréia adequada.

Desse modo, modelos matemáticos têm sido desenvolvidos na tentativa de predizer as concentrações-alvo de NUL e, dessa forma, facilitar seu uso na avaliação da adequação nutricional de dietas e na predição do nitrogênio excretado para o ambiente.

Os modelos matemáticos de predição de NUL, encontrados na literatura e que foram estudados neste trabalho, consideram a maioria dos fatores conhecidos em afetar as concentrações de NUL, incluindo consumo de nitrogênio, produção de leite e percentagem de proteína do leite. Adicionalmente, um dos modelos foi ajustado para 
efeitos do peso corporal. Os três modelos são derivados de um primeiro modelo, proposto por Jonker et al. (1998) para predição de nitrogênio urinário (NU). O modelo 1 de predição de NUL (NU/12,54) foi desenvolvido por Jonker e colaboradores em 1998. Os outros dois modelos são mais recentes (Kauffman \& St. Pierre, 2001).

Kohn et al. (2002) relataram que, em setembro de 1998, foi descoberto um defeito de "hardware" nos equipamentos de análise de NUL que estavam sendo usados pelos laboratórios do DHIA (Dairy Herd Improvement Association) nos EUA para analisar as amostras de curva-padrão. Quando esse defeito foi corrigido, os padrões de NUL mudaram, de modo que os laboratónios relataram valores menores. Torna-se, pois, difícil interpretar os valores de NUL nos modelos que haviam sido desenvolvidos anteriormente, como é o caso do modelo 1 (Jonker et al., 1998).

Outro fato importante a ser considerado é que esses modelos foram desenvolvidos a partir de dados experimentais americanos. Assim, para que suas futuras utilizações sejam possíveis, eles deverão ser avaliados nas condições de campo brasileiras, usando dados de rebanho comercial. Desse modo, poderão fornecer resultados acurados e confiáveis de predição das concentrações de nitrogênio uréico no leite, o que foi o objetivo do presente trabalho.

\subsection{Material e Métodos}

\subsubsection{Coleta de dados}

No estudo, foram utilizadas 8.833 observações, provenientes de 855 vacas da raça Holandesa, pertencentes ao rebanho da Fazenda Colorado, situada no município de Araras, estado de São Paulo. Essas observações foram coletadas no período compreendido entre setembro de 2000 e janeiro de 2002.

Os animais foram confinados em estábulo do tipo "free-stall", dotado de ventiladores e aspersores, acionados automaticamente quando a temperatura ultrapassava $23^{\circ} \mathrm{C}$. Após o parto, os animais foram ordenhados em sala do tipo "espinha 
de peixe", 2 x 12, linha baixa, com sistema de coleta de dados AFIMILK® - SAE AFIKIM, em que cada animal é identificado e sua produção de leite registrada, diariamente.

Os animais foram alimentados 7 vezes ao dia, sendo o primeiro fornecimento às $5 \mathrm{~h}$ e o último, às $21 \mathrm{~h}$. Receberam dieta total e única, composta de silagem de milho, silagem pré-secada de gramínea, farelo de soja, gérmen de milho, silagem de grão úmido de milho, farelo de glúten de milho, polpa cítrica e mistura mineral, em que o volumoso correspondeu a $48 \%$ da dieta em MS. Para a alimentação do rebanho, foi utilizado vagão de mistura total (TMR) de $10 \mathrm{~m}^{3}$, com desensilador e balança eletrônica. A dieta foi balanceada segundo NRC (1989) e sua composição estimada média está apresentada na Tabela 1.

Tabela 1. Composição estimada das dietas e consumo médio real de matéria seca do rebanho

\begin{tabular}{lcccccccc}
\hline Meses & \multicolumn{7}{c}{ Composição estimada da dieta } \\
& MS & PB & EE & FDN & FDA & CNF & MM & CMS \\
\hline set./2000 & 47,2 & 17,10 & 3,15 & 34,04 & 19,69 & 38,77 & 6,37 & 20,9 \\
out./2000 & 46,3 & 17,31 & 3,12 & 33,22 & 19,30 & 39,83 & 6,03 & 20,5 \\
nov./2000 & 46,8 & 17,67 & 3,09 & 32,72 & 19,40 & 39,69 & 6,28 & 20,3 \\
dez./2001 & 48,3 & 16,49 & 3,88 & 33,03 & 19,59 & 39,99 & 6,13 & 22,9 \\
jan./2001 & 49,8 & 15,91 & 4,20 & 31,04 & 18,52 & 42,27 & 6,08 & 19,3 \\
fev./2001 & 48,8 & 16,47 & 4,12 & 31,16 & 18,46 & 41,58 & 6,18 & 16,9 \\
abr./2001 & 49,2 & 16,48 & 4,06 & 29,83 & 17,89 & 43,02 & 6,12 & 16,8 \\
mai./2001 & 49,6 & 16,69 & 4,30 & 30,95 & 17,99 & 41,34 & 6,19 & 18,4 \\
jun./2001 & 50,1 & 16,80 & 5,34 & 32,88 & 19,24 & 37,97 & 6,37 & 19,1 \\
jul./2001 & 50,4 & 16,82 & 5,37 & 32,97 & 19,31 & 37,81 & 6,38 & 20,0 \\
ago./2001 & 50,4 & 16,90 & 4,26 & 33,48 & 19,66 & 38,55 & 6,22 & 23,2 \\
set./2001 & 50,4 & 16,90 & 4,26 & 33,48 & 19,66 & 38,55 & 6,22 & 22,6 \\
out./2001 & 49,7 & 17,11 & 4,19 & 33,02 & 19,63 & 37,70 & 7,21 & 23,3 \\
nov./2001 & 49,7 & 17,11 & 4,19 & 33,02 & 19,63 & 37,70 & 7,21 & 21,9 \\
dez./2001 & 50,1 & 17,11 & 4,19 & 33,02 & 19,63 & 37,70 & 7,21 & 22,9 \\
jan./2002 & 50,1 & 17,00 & 4,68 & 32,81 & 19,51 & 37,52 & 7,23 & 23,8 \\
\hline MS = matéria 5 seca (\%); PB = proteína bruta (\% MS); EE =extrato etéreo (\% MS); FDN = fibra em \\
detergente neutro (\% MS); FDA = fibra em detergente ácido (\% MS); CNF = carboidratos não-fibrosos \\
(\% MS); MM = matéria mineral (\% MS); CMS = consumo médio de matéria seca do rebanho \\
(kg/animal/dia).
\end{tabular}


Dados zootécnicos sobre produção de leite $(\mathrm{kg})$, peso vivo do animal (kg), dias em lactação (DEL) e número de lactações (NL) foram coletados no dia da amostragem do leite. As amostras de leite foram coletadas mensalmente, sempre na ordenha da manhã, transferidas diretamente do medidor para os frascos de coleta (60 $\mathrm{mL}$ ), cada um contendo duas pastilhas de bronopol (largo espectro) como conservante e homogeneizadas por, no mínimo, 15 segundos. Foram, então, encaminhadas à Clínica do Leite do Departamento de Zootecnia da Escola Superior de Agricultura "Luiz de Queiroz"/Universidade de São Paulo, para determinação das concentrações de gordura, proteína, lactose, sólidos totais (ST) (\%) e NUL (mg/dL), bem como de contagem de células somáticas $(\mathrm{CCS})\left(\mathrm{x} 10^{3}\right.$ células $\left./ \mathrm{mL}\right)$.

As concentrações de gordura, proteína, lactose e sólidos totais foram determinadas por leitura de absorção infravermelha pelo equipamento Bentley $2000 \AA$ (Bentley Instruments, 1995a) e a CCS foi executada por citometria fluxométrica pelo equipamento Somacount 300® (Bentley Instruments, 1995b). As concentrações de NUL foram determinadas utilizando-se o equipamento ChemSpeck $150 \AA$, por meio de método enzimático e espectrofotométrico de trans-reflectância (Bentley Instruments, 1998).

As épocas de parição e épocas do ano foram divididas em verão (de novembro a abril) e inverno (de maio a outubro). A relação gordura/proteína (rel. G/P) foi obtida pela divisão entre a percentagem de gordura e a de proteína do leite. A contagem de células somáticas (CCS x $10^{3}$ células $/ \mathrm{mL}$ ) foi transformada em logaritmo natural (LCCS) pela equação $\ln (\mathrm{CCS}+1)$, pois não possui distribuição normal (Godden et al., 2001b).

A produção de leite corrigida para $4 \%$ de gordura (LCG4\%) foi calculada pela seguinte equação: $(0,4 * \mathrm{~kg}$ de leite produzido $)+\left(15^{*} \mathrm{~kg}\right.$ de gordura produzida), de acordo com NRC (1989). O consumo de matéria seca foi estimado pela equação do NRC (2001), como segue:

$C M S=\left(\left(0,0968 * P V^{0,75}\right)+(0,372 * L C G 4 \%)-0,293\right) *\left(1-e^{(-0,192 *(S L+3,67))}\right)$, 
sendo: $\mathrm{CMS}$ = consumo de matéria seca $(\mathrm{kg} / \mathrm{animal} / \mathrm{dia})$; $\mathrm{LCG} 4 \%$ = produção de leite corrigida para $4 \%$ de gordura (kg/animal/dia); PV = peso vivo $(\mathrm{kg}) ; \mathrm{SL}=$ semana de lactação. A LCG4\% foi usada no cálculo de CMS (NRC, 2001) e esse último, usado indiretamente no cálculo dos modelos de predição de NUL, ao se calcular a ingestão de nitrogênio (IN).

\subsubsection{Modelos estudados}

Os três modelos foram derivados de um primeiro modelo, proposto por Jonker et al. (1998) para predição de nitrogênio urinário (NU), como segue:

$\mathrm{NU}=(\mathrm{IN} \times 0,83)-$ NLeite -97 ;

sendo $\mathrm{NU}=$ excreção de nitrogênio urinário (g/dia); $\mathrm{IN}=$ ingestão de nitrogênio (g/animal/dia) e NLeite = secreção de nitrogênio no leite $(\mathrm{g} / \mathrm{animal} / \mathrm{dia})$.

A digestibilidade verdadeira da fonte de nitrogênio de 0,83 e o nitrogênio metabólico fecal de $97 \mathrm{~g} / \mathrm{dia}$ foram assumidos por Jonker et al. (1998), ao estudarem, previamente, uma grande variedade de dietas. Esse modelo assume que o nitrogênio retido, usado para crescimento e reservas, é ínfimo para vacas multíparas. O NRC (2001) assume que o nitrogênio metabólico fecal é uma função do peso corporal; entretanto, Jonker et al. (1998) ao desenvolverem esse modelo, não o incluíram, pois consideraram que a complexidade adicionada ao modelo não se justificaria.

Para calcular a excreção de nitrogênio urinário, o consumo de matéria seca (CMS) foi usado especificamente na equação para o cálculo da ingestão de nitrogênio. Foram estudados 3 métodos de estimar o CMS: o primeiro foi estimar o CMS individual pelo NRC (2001); no segundo método, utilizourse o CMS real médio do rebanho como sendo o consumo de cada animal (consumo real médio mensal do rebanho para estimar o consumo de matéria seca individual); o terceiro utilizou os dados de CMS real médio mensal de todo o rebanho para predizer a concentração média de NUL do rebanho.

Por fim, o nitrogênio urinário foi usado para predizer NUL. Desse modo, o cálculo dos modelos 1, 2 e 3 para predição de NUL incluiu o consumo de nitrogênio, a 
produção de leite e a percentagem de proteína do leite. Adicionalmente, o modelo 3 foi ajustado para o efeito de peso vivo. As concentrações preditas de NUL dependeram do modelo usado e foram obtidas das seguintes equações:

- modelo 1: NUL = NU/12,54 (Jonker et al., 1998);

- modelo 2: NUL = NU/17,6 (Kauffman \& StPierre, 2001);

- modelo 3: NUL = NU/(0,0259 x PV) (Kauffman \& StPierre, 2001);

em que: $\mathrm{NUL}=$ nitrogênio uréico no leite $(\mathrm{mg} / \mathrm{dL}) ; \mathrm{NU}=$ nitrogênio urinário (g/animal/dia) e PV = peso vivo $(\mathrm{kg})$. $\mathrm{O}$ modelo 1 , como foi desenvolvido a partir de concentrações de NUL obtidas anteriormente à correção das curvas-padrão de NUL, será denominado antigo e os modelos 2 e 3 serão denominados recentes, por terem sido desenvolvidos com dados obtidos após a correção dos valores de NUL.

A proposta desses modelos é identificar quando NUL desvia de um valor esperado, podendo, assim, indicar problema potencial de manejo. Ao usar os 3 diferentes modelos, NUL esperado foi predito a partir de parâmetros da dieta e de produção, sendo esses valores comparados com os valores observados de NUL.

As 8.844 observações foram utilizadas nos modelos 1 e 2. Entretanto, para o modelo 3 , foram utilizadas apenas 4.749, pois foram as que continham o peso vivo dos animais. Para o cálculo do CMS, pelo NRC (2001), foram também usadas 4.749 observações, pelo mesmo motivo citado anteriormente.

\subsubsection{Avaliação dos modelos}

Para a avaliação dos modelos, foram medidas a acurácia, a precisão e a robustez dos 3 modelos testados. A acurácia e a precisão dos modelos foram determinadas pela comparação dos dados preditos com os observados. Por sua vez, a robustez foi determinada pela comparação dos valores preditos menos os observados (vieses) com outros fatores estudados (Kohn et al., 1998).

De acordo com Kohn et al. (1998), a acurácia dos modelos é avaliada por meio do viés médio. $\mathrm{O}$ viés é a diferença entre o valor predito pelo modelo e o valor observado de NUL e representa a inacurácia média das predições do modelo. Portanto, o 
modelo mais acurado é aquele que possui um viés médio mais próximo do valor zero. A acurácia é medida pela fórmula a seguir:

Viés médio $=\frac{\sum(\text { predito }- \text { observado })}{n^{o} \text { observações }}$

A precisão é uma medida de dispersão entre os valores preditos e observados, ou seja, é a variabilidade média da distância entre o valor predito e o valor observado. Ela pode ser avaliada pela raiz quadrada média do erro de predição (RQMEP) ou pelo erro residual. A RQMEP ou RMSPE ("root mean square prediction error”) (Bibby \& Toutenburg, 1977) é uma medida de quanto as predições se adequam bem aos dados observados e foi calculada pela seguinte fórmula:

$\mathrm{RQMEP}=\sqrt{\frac{\sum(\text { predito }- \text { observado })^{2}}{n^{o} \text { observações }}}$

Entretanto, segundo Rodrigues (2002) ${ }^{1}$, toda vez que o viés médio for alto (falta de acurácia), haverá superestimativa da falta de precisão, ou seja, superestimativa da RQMEP, uma vez que a distância média entre o valor predito e o observado leva também ao aumento da variabilidade entre o predito e o observado. Portanto, a precisão é mais bem avaliada quando a RQMEP é corrigida para falta de acurácia, gerando, assim, o erro residual, que é definido como o erro restante no modelo de predição, excluindo-se o erro devido ao viés médio. O ero residual é também referido como o erro de predição, excluindo-se o viés médio, sendo obtido pela fórmula:

Erro residual $=\sqrt{\left[R Q M E P^{2}-(\text { viésmédio })^{2}\right]}$

O viés linear para NUL foi derivado regredindo-se o viés (NUL predito NUL observado) versus NUL observado e pode ser usado para identificar se a magnitude do viés aumenta, diminui ou não existe com a magnitude dos valores observados de NUL (Bibby \& Toutenburg, 1977).

A robustez é a caracterização do modelo que menos é influenciado por outros fatores selecionados (número de lactação, dias em lactação, peso vivo, produção

\footnotetext{
${ }^{1}$ RODRIGUES, P.H.M. (Faculdade de Medicina Veterinária e Zootecnia da Universidade de São Paulo, Pirassununga/SP). Comunicação pessoal, 2002.
} 
de leite, concentração de gordura, proteína, lactose e sólidos totais do leite, logaritmo natural da contagem de células somáticas (LCCS), época de parição e época do ano). Para que o modelo se enquadre nesse conceito, deve possuir, em relação às retas de regressão do viés versus variáveis, pequenos coeficientes angulares ("slope") e de determinação $\left(\mathrm{R}^{2}\right)$ e, ainda, inexistência de inclinação da reta indicada por altas probabilidades estatísticas (Rodrigues, 2002) ${ }^{1}$.

\subsubsection{Análise estatística}

Para se comparar a acurácia entre os modelos, o viés médio foi submetido à análise de variância (teste $F$ ) e a comparação entre as médias foi realizada pelo teste de Tukey (5\%). Para determinação da significância do valor médio do viés, ou seja, se era significativamente diferente de 0 , foi utilizado o teste $T$ para média igual a 0 , pelo PROC UNIVARIATE (SAS, 1985). Para se comparar a precisão entre os modelos, os valores do erro residual foram submetidos ao teste de homogeneidade de variâncias (teste de Hartley), sendo comparados dois a dois, utilizando-se, para tal, o PROC TTEST (SAS, 1985), segundo Ott (1993).

O viés linear para NUL foi derivado regredindo-se o viés (NUL predito NUL observado) versus NUL observado pelo PROC REG (SAS, 1985). Por sua vez, a avaliação da robustez de cada modelo foi obtida regredindo-se o viés contra as variáveis selecionadas (número de lactação, dias em lactação, peso vivo, produção de leite, concentração de gordura, proteína, lactose e sólidos totais do leite, logaritmo natural da contagem de células somáticas (LCCS), época de parição e época do ano) pelo PROC REG (SAS, 1985). A comparação entre os coeficientes angulares das retas foi realizada pela metodologia de comparação de retas, cujo princípio é avaliar a interação entre a variável selecionada e os modelos, por meio de análise de variância (teste F) pelo PROC GLM do SAS (1985), sendo comparados dois a dois.

\footnotetext{
${ }^{1}$ RODRIGUES, P.H.M. (Faculdade de Medicina Veterinária e Zootecnia da Universidade de São Paulo, Pirassununga/SP). Comunicação pessoal, 2002.
} 


\subsection{Resultados e Discussão}

A concentração média de NUL, encontrada neste estudo, foi de 13,15 $\mathrm{mg} / \mathrm{dL}$. As vacas apresentaram, em média, $662 \mathrm{~kg}, 2,3$ números de lactações, 197 dias em lactação e produção de leite de 34,2 kg/dia.

6.3.1 Validação dos modelos usando o consumo individual de matéria seca estimado pelo NRC 2001

Os resultados da acurácia e precisão dos 3 modelos testados, utilizando-se o consumo individual de matéria seca estimado pelo NRC (2001), estão apresentados na Tabela 2. 
Tabela 2. Número amostral, viés médio (acurácia), erro residual (precisão), raiz quadrada média do erro de predição (RQMEP) e coeficiente de determinação $\left(R^{2}\right)$, para os modelos 1,2 e 3, e regressão entre viés e NUL observado, usando os dados de consumo individual de matéria seca estimado pelo NRC 2001

\begin{tabular}{|c|c|c|c|}
\hline & Modelo 1 & Modelo 2 & Modelo 3 \\
\hline Número amostral & 4.749 & 4.749 & 4.749 \\
\hline NUL observado & 13,81 & 13,81 & 13,81 \\
\hline NUL predito & 20,75 & 14,75 & 15,22 \\
\hline Viés médio $^{1,2}$ & $6,94 \mathrm{~A} * *$ & $0,94 \mathrm{C} * *$ & $1,41 \mathrm{~B} * *$ \\
\hline Erro residual $^{3}$ & $5,40 \mathrm{~A}$ & $4,50 \mathrm{~B}$ & $4,11 \mathrm{C}$ \\
\hline RQMEP $^{4}$ & 8,79 & 4,60 & 4,35 \\
\hline \multirow[t]{2}{*}{$\mathrm{R}^{2}$} & 0,001327 & 0,001327 & 0,007868 \\
\hline & \multicolumn{3}{|c|}{ Regressão entre viés e NUL observado ${ }^{5}$} \\
\hline Viés linear, ${ }^{6,7}$ & $-0,9540 \mathrm{AB}$ & $-0,9673 B$ & $-0,9320 \mathrm{~A}$ \\
\hline $\mathrm{R}^{2}$ (Probabilidade) $^{8}$ & $0,3639(<0,0001)$ & $0,5378(<0,0001)$ & $0,5985(<0,0001)$ \\
\hline \multicolumn{4}{|c|}{$\begin{array}{l}\text { Médias na mesma linha, seguidas de diferentes letras, são diferentes }(\mathrm{P}<0,05) \text { pelo teste de Tukey. } \\
{ }^{2} \text { Probabilidade do teste } T \text { para média }=0 .{ }^{* *} \text { Média diferente de } 0 \text { (zero) a } 1 \% \text {. } \\
{ }^{3} \text { Erros residuais na mesma linha, seguidos de diferentes letras, são diferentes pelo teste de Hartley } \\
\text { (P<0,05), realizado } 2 \text { a } 2 \text {. } \\
{ }^{4} \text { Raiz quadrada média do erro de predição. } \\
{ }^{5} \text { Regressão entre (NUL predito - NUL observado) e NUL observado. } \\
{ }^{6} \text { Coeficiente angular da regressão entre (NUL predito - NUL observado) e NUL observado. } \\
{ }^{7} \text { Médias na mesma linha, seguidas de diferentes letras, são diferentes (P<0,05) pela metodologia de } \\
\text { comparação de retas (análise de variância). } \\
{ }^{8} \text { Coeficiente de determinação e probabilidade da existência ou não de inclinação da reta (teste F). }\end{array}$} \\
\hline
\end{tabular}

Ao analisar os vieses médios (Tabela 2), nota-se, para o modelo 1, que as predições de NUL superestimaram as concentrações observadas em, aproximadamente, $50 \%$, ou em 6,94 mg/dL. Por sua vez, o modelo 2 superestimou os valores de NUL em, aproximadamente, $7 \%(0,94 \mathrm{mg} / \mathrm{dL})$ e o modelo 3, em, aproximadamente, $10 \%(1,41$ mg/dL). Assim, observa-se que todos os modelos mostraram falta de acurácia, uma vez que apresentaram média de viés diferente de $0(\mathrm{P}<0,01)$. No entanto, as medidas de acurácia dos modelos, representadas pelas médias dos vieses, apresentaram diferenças entre si $(\mathrm{P}<0,05)$, apontando que o modelo 2 é o mais acurado por apresentar o menor 
viés médio $(0,94 \mathrm{mg} / \mathrm{dL})$, enquanto o modelo 1 é o menos acurado $(6,94 \mathrm{mg} / \mathrm{dL})$ (Tabela 2).

Observa-se, também, que a precisão (erros residuais) dos 3 modelos diferem entre si, de modo que o modelo mais preciso é o modelo $3(4,11)$ e o menos preciso é o modelo 1 (5,40). As RQMEP foram de 8,79, 4,60 e 4,35 mg/dL para os modelos 1, 2 e 3, respectivamente. Assim, o modelo 2, apesar de mais acurado, é medianamente preciso, apresentando erro residual de 4,50 (Tabela 2). Por outro lado, o modelo 1 foi o menos acurado e o menos preciso.

Ao se regredir viés (NUL predito - NUL observado) versus NUL observado, observam-se vieses lineares (coeficientes angulares das retas) negativos $(\mathrm{P}<0,0001)$ de $-0,9540,-0,9673$ e $-0,9320 \mathrm{mg} / \mathrm{dL}$ para os modelos 1,2 e 3, respectivamente (Tabela 2). Isso significa que o viés (predito - observado) foi menor quanto maior o valor observado de NUL. Entretanto, o viés linear do modelo 3 diferiu do modelo 2 ( $\mathrm{P}=0,0390)$, mas não do modelo 1 ( $\mathrm{P}=0,3039)$, assim como o viés linear do modelo 2 não diferiu do modelo 1 ( $\mathrm{P}=0,5541)$. Esses vieses lineares podem ser observados na Figura 1. 


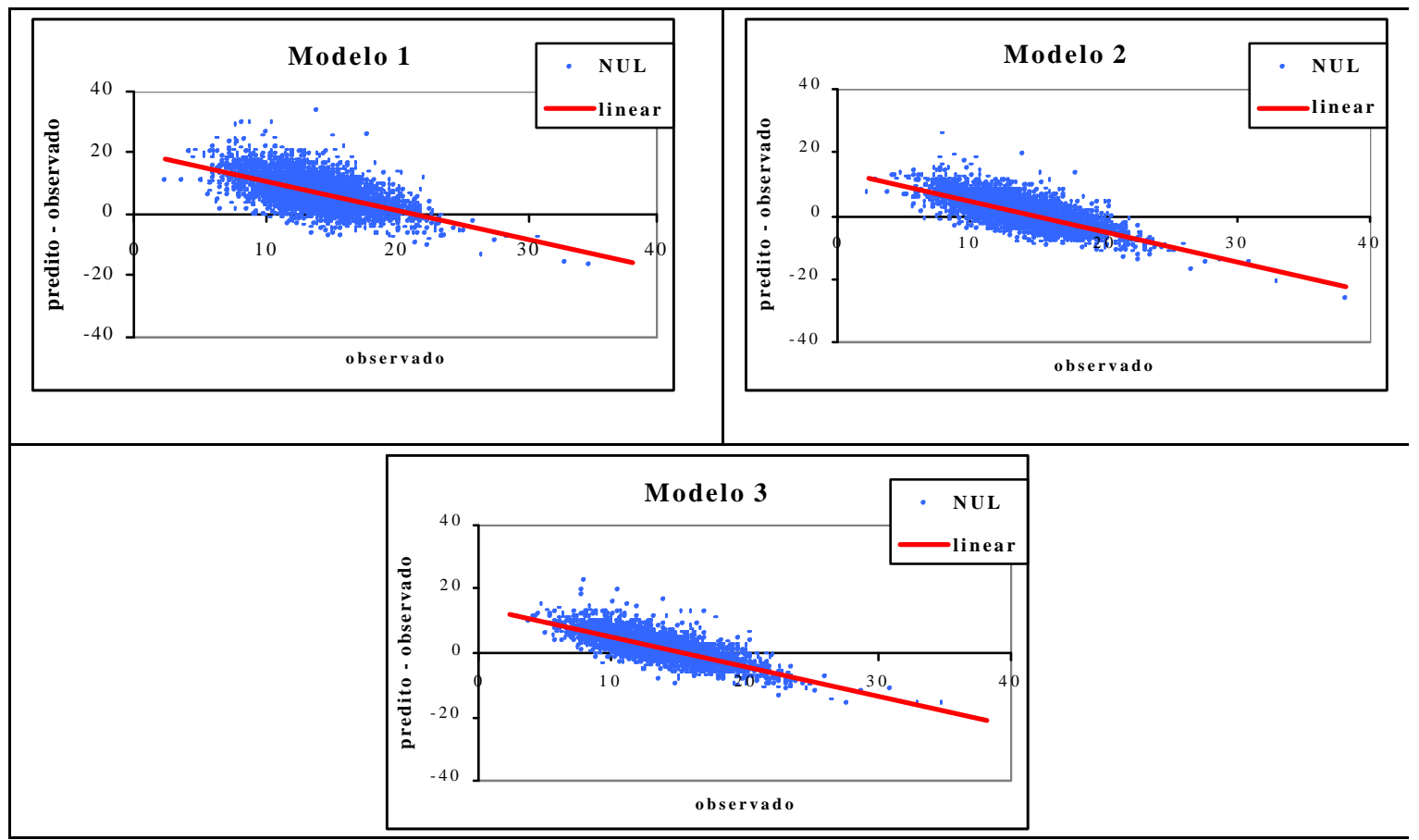

Figura 1- Vieses lineares para NUL, regredindo-se o viés (NUL predito - NUL observado) versus NUL observado para os modelos 1,2 e 3, usando o consumo individual de matéria seca estimado pelo NRC (2001)

Na Tabela 3, está apresentada a avaliação de robustez dos modelos. Observa-se que os 3 modelos foram influenciados por quase todas as variáveis estudadas ( $\mathrm{P}<0,01)$. Entretanto, o modelo 3 também não foi afetado pelo LCCS $(\mathrm{P}=0,4204)$, nem pela época de parição $(\mathrm{P}=0,2194)$. Pelo coeficiente de determinação $\left(\mathrm{R}^{2}\right)$, visualmente, observa-se que a concentração de gordura, a relação gordura/proteína e a concentração de sólidos totais apresentaram os maiores valores, indicando que essas variáveis podem explicar variações nos modelos. Além disso, elas também apresentaram os maiores coeficientes angulares, incluindo, ainda, a concentração de lactose e a época do ano, apesar de seus $\mathrm{R}^{2}$ serem baixos. 
Tabela 3. Avaliação de robustez (slope, $\mathrm{R}^{2}$ e probabilidade) para os modelos 1,2 e 3 , incluindo outras variáveis, usando o consumo individual de matéria seca estimado pelo NRC (2001)

\begin{tabular}{|c|c|c|c|c|}
\hline Variáveis estudadas & & Modelo 1 & Modelo 2 & Modelo 3 \\
\hline Número de lactação & $\begin{array}{c}\text { Slope } \\
\left.\mathrm{R}^{2} \text { (Prob. }\right)^{4}\end{array}$ & $\begin{array}{c}0,9551 \mathrm{~A} \\
0,0626(<0,0001)\end{array}$ & $\begin{array}{c}0,6073 \mathrm{~B} \\
0,0364(<0,0001)\end{array}$ & $\begin{array}{c}-0,2384 \mathrm{C} \\
0,0067(<0,0001)\end{array}$ \\
\hline Dias em lactação & $\begin{array}{c}\text { Slope } \\
\mathrm{R}^{2} \text { (Prob.) }\end{array}$ & $\begin{array}{c}0,0091 \mathrm{~A} \\
0,0448(<0,0001)\end{array}$ & $\begin{array}{c}0,0078 \mathrm{~A} \\
0,0477(<0,0001)\end{array}$ & $\begin{array}{c}0,0018 \mathrm{~B} \\
0,0031(<0,0001)\end{array}$ \\
\hline Peso corporal (kg) & $\begin{array}{c}\text { Slope } \\
\mathrm{R}^{2} \text { (Prob.) }\end{array}$ & $\begin{array}{c}0,0271 \mathrm{~A} \\
0,2362(<0,0001)\end{array}$ & $\begin{array}{c}0,0198 \mathrm{~B} \\
0,1806(<0,0001)\end{array}$ & $\begin{array}{c}-0,0018 \mathrm{C} \\
0,0018(0,0034)\end{array}$ \\
\hline Produção de leite (kg/dia) & $\begin{array}{c}\text { Slope } \\
\mathrm{R}^{2} \text { (Prob.) }\end{array}$ & $\begin{array}{c}0,0948 \mathrm{~A} \\
0,0256(<0,0001)\end{array}$ & $\begin{array}{c}0,0464 \mathrm{~B} \\
0,0088(<0,0001)\end{array}$ & $\begin{array}{c}0,0610 \mathrm{~B} \\
0,0182(<0,0001)\end{array}$ \\
\hline Gordura do leite (\%) & $\begin{array}{c}\text { Slope } \\
\mathrm{R}^{2} \text { (Prob.) }\end{array}$ & $\begin{array}{c}3,2825 \mathrm{~A} \\
0,2502(<0,0001)\end{array}$ & $\begin{array}{c}2,5417 \mathrm{~B} \\
0,2157(<0,0001)\end{array}$ & $\begin{array}{c}2,3549 \mathrm{C} \\
0,2219(<0,0001)\end{array}$ \\
\hline Proteína do leite (\%) & $\begin{array}{c}\text { Slope } \\
\mathrm{R}^{2} \text { (Prob.) }\end{array}$ & $\begin{array}{c}0,7619 \mathrm{~A} \\
0,0024(0,0007)\end{array}$ & $\begin{array}{c}1,0037 \mathrm{~A} \\
0,0061(<0,0001)\end{array}$ & $\begin{array}{c}-0,5942 \text { B } \\
0,0026(0,0005)\end{array}$ \\
\hline Relação gordura/proteína & $\begin{array}{c}\text { Slope } \\
\mathrm{R}^{2} \text { (Prob.) }\end{array}$ & $\begin{array}{c}10,4857 \mathrm{~A} \\
0,2463(<0,0001)\end{array}$ & $\begin{array}{c}7,8573 \mathrm{~B} \\
0,1989(<0,0001)\end{array}$ & $\begin{array}{c}8,2603 \mathrm{~B} \\
0,2635(<0,0001)\end{array}$ \\
\hline Lactose $(\%)$ & $\begin{array}{c}\text { Slope } \\
\mathrm{R}^{2} \text { (Prob.) }\end{array}$ & $\begin{array}{c}-2,2982 \mathrm{C} \\
0,01885(<0,0001)\end{array}$ & $\begin{array}{c}-1,5482 \mathrm{~B} \\
0,0123(<0,0001)\end{array}$ & $\begin{array}{c}0,9965 \mathrm{~A} \\
0,0061(<0,0001)\end{array}$ \\
\hline Sólidos totais do leite $(\%)$ & $\begin{array}{c}\text { Slope } \\
\mathrm{R}^{2} \text { (Prob.) }\end{array}$ & $\begin{array}{c}1,8378 \mathrm{~A} \\
0,1312(<0,0001)\end{array}$ & $\begin{array}{c}1,5048 \mathrm{~B} \\
0,1265(<0,0001)\end{array}$ & $\begin{array}{c}1,4729 \mathrm{~B} \\
0,1453(<0,0001)\end{array}$ \\
\hline $\mathrm{LCCS}^{1}$ & $\begin{array}{c}\text { Slope } \\
\mathrm{R}^{2} \text { (Prob.) }\end{array}$ & $\begin{array}{c}0,3850 \mathrm{~A} \\
0,0115(<0,0001)\end{array}$ & $\begin{array}{c}0,3574 \mathrm{~A} \\
0,0143(<0,0001)\end{array}$ & $\begin{array}{c}0,0319 \mathrm{~B} \\
0,0001(0,4204)\end{array}$ \\
\hline Época de parição & $\begin{array}{c}\text { Slope } \\
\mathrm{R}^{2} \text { (Prob.) }\end{array}$ & $\begin{array}{c}0,8181 \mathrm{~A} \\
0,0056(<0,0001)\end{array}$ & $\begin{array}{c}0,7417 \mathrm{~A} \\
0,0066(<0,0001)\end{array}$ & $\begin{array}{c}0,1485 \mathrm{~B} \\
0,0003(0,2194)\end{array}$ \\
\hline Época do ano & $\begin{array}{c}\text { Slope } \\
\mathrm{R}^{2} \text { (Prob.) }\end{array}$ & $\begin{array}{c}-2,7077 \mathrm{~B} \\
0,0601(<0,0001)\end{array}$ & $\begin{array}{c}-2,2231 \mathrm{~A} \\
0,0583(<0,0001)\end{array}$ & $\begin{array}{c}-2,1561 \mathrm{~A} \\
0,0657(<0,0001)\end{array}$ \\
\hline \multicolumn{5}{|c|}{$\begin{array}{l}{ }^{1} \text { logaritmo natural da }(\mathrm{CCS}+1) \text {. } \\
{ }^{2} \text { coeficiente angular da reta } \mathrm{y}=\mathrm{a}+\mathrm{bX} \text {, regredindo-se o viés (NUL predito }-\mathrm{NUL} \text { observado) versus } \\
\text { variáveis. } \\
{ }^{3} \text { comparação entre coeficientes angulares das retas, em que letras diferentes na mesma linha diferem entre } \\
\text { si pela metodologia de comparação de retas (análise de variância) }(\mathrm{P}<0,05) \text {. } \\
4^{4} \text { coeficiente de determinação e probabilidade de a análise de variância indicar existência ou não de } \\
\text { inclinação da reta (teste } F \text { ). }\end{array}$} \\
\hline
\end{tabular}

$\mathrm{O}$ peso corporal para o modelo 1 apresentou $\mathrm{R}^{2}$ relativamente alto (0,2362), mas, para o modelo 3 , o $\mathrm{R}^{2}$ foi baixo $(0,0018)$, apresentando, também, coeficiente angular menor $(\mathrm{P}<0,05)$ que os dos outros dois modelos (Tabela 3). Cabe ressaltar que o modelo 3 já havia sido previamente corrigido para o peso em sua equação. Entretanto, para as estimativas de consumo pelo NRC (2001), o peso corporal 
também já havia sido incluído em sua equação original. Dunlap et al. (2000), ao testarem o modelo 1, observaram efeito linear do peso corporal sobre as concentrações preditas de NUL, de forma que as predições foram maiores que os valores observados para vacas mais pesadas e menores para vacas mais leves.

O modelo 1, proposto por Jonker et al. (1998), estima uma taxa renal de excreção ("clearance") para todas as vacas igual a $1.254 \mathrm{~L} /$ dia. Porém, tais autores afirmaram que vacas maiores têm mais sangue que as menores e, com o mesmo consumo de proteína, são mais propensas a ter maior taxa renal de excreção, enquanto vacas menores são mais propensas a ter menores taxas (Jonker et al., 1998). Ambos os efeitos teriam como conseqüência redução do NUL predito para vacas maiores e aumento para vacas mais leves.

Apesar de esses efeitos terem sido notados por Jonker et al. (1999), eles relataram que menos de $3 \%$ da variação do seu modelo foi atribuído ao peso corporal. Desse modo, o peso corporal não foi incluído no modelo 1, pois os dados usados em seu desenvolvimento não foram suficientemente robustos para serem considerados. Eles, ainda, complementaram que a variação nas medições de peso corporal causada pelo enchimento gastrointestinal, volume de leite na glândula mamária e métodos de medições parecem adicionar tanta variação nas predições de seu modelo original (Jonker et al., 1998) que a sua inclusão não se justificou.

Para a regressão dos vieses versus a produção de leite, apesar de os coeficientes angulares da reta dos 3 modelos serem diferentes de $0(\mathrm{P}<0,0001)$, seus valores foram baixos, assim como os coeficientes de determinação (Tabela 3), provavelmente, devido à prévia correção dos modelos ao se utilizar o CMS estimado pelo NRC (2001), que possui a produção de leite em sua equação. Cabe, ainda, lembrar que a produção de leite e a percentagem de proteína foram consideradas no modelo de predição de nitrogênio urinário (NU), que foi usado para predizer o NUL. Desse modo, a falta de influência da produção de leite demonstra que o modelo acuradamente considera seu efeito. 


\subsubsection{Validação dos modelos usando o consumo real médio mensal do rebanho para estimar o consumo de matéria seca individual}

Os resultados das avaliações de acurácia e precisão para os 3 modelos testados, utilizando-se o consumo real médio mensal do rebanho para estimar o consumo de matéria seca individual, estão apresentados na Tabela 4.

Tabela 4. Número amostral, viés médio (acurácia), erro residual (precisão), raiz quadrada média do erro de predição (RQMEP) e coeficiente de determinação $\left(R^{2}\right)$, para os modelos 1,2 e 3, e regressão entre viés e NUL observado, usando os dados de consumo real médio mensal do rebanho para estimar o consumo de matéria seca individual

\begin{tabular}{|c|c|c|c|}
\hline & Modelo 1 & Modelo 2 & Modelo 3 \\
\hline Número amostral & 8.833 & 8.833 & 4.749 \\
\hline NUL observado & 13,16 & 13,16 & 13,81 \\
\hline NUL predito & 16,09 & 11,44 & 13,60 \\
\hline Viés médio ${ }^{1,2}$ & $2,93 \mathrm{~A} * *$ & $-1,72 \mathrm{C} * *$ & $-0,21 \mathrm{~B} * *$ \\
\hline Erro residual $^{3}$ & 5,99 A & $4,90 \mathrm{C}$ & $5,24 \mathrm{~B}$ \\
\hline $\mathrm{RQMEP}^{4}$ & 6,66 & 5,19 & 5,25 \\
\hline \multirow[t]{2}{*}{$\mathrm{R}^{2}$} & 0,0132 & 0,0132 & 0,00584 \\
\hline & \multicolumn{3}{|c|}{ Regressão entre viés e NUL observado 5} \\
\hline Viés linear ${ }^{6,7}$ & $-0,8408 \mathrm{~A}$ & $-0,8868 \mathrm{~B}$ & $-1,0835 \mathrm{C}$ \\
\hline $\mathrm{R}^{2}$ (Probabilidade) ${ }^{8}$ & $0,2719(<0,0001)$ & $0,4512(<0,0001)$ & $0,4972(<0,0001)$ \\
\hline \multicolumn{4}{|c|}{$\begin{array}{l}\text { Médias na mesma linha, seguidas de diferentes, letras são diferentes }(\mathrm{P}<0,05) \text { pelo teste de Tukey. } \\
{ }^{2} \text { Probabilidade do teste } T \text { para média }=0 \text {. ** Média diferente de } 0 \text { (zero) a } 1 \% \text {. } \\
{ }^{3} \text { Erros residuais na mesma linha, seguidos de diferentes letras, são diferentes pelo teste de Hartley } \\
\text { (P<0,05), realizado } 2 \text { a } 2 \text {. } \\
{ }^{4} \text { Raiz quadrada média do erro de predição. } \\
{ }^{5} \text { Regressão entre (NUL predito - NUL observado) e NUL observado. } \\
{ }^{6} \text { Coeficiente angular da regressão entre (NUL predito - NUL observado) e NUL observado. } \\
{ }^{7} \text { Médias na mesma linha, seguidas de diferentes letras, são diferentes }(\mathrm{P}<0,05) \text { pela metodologia de } \\
\text { comparação de retas (análise de variância). }\end{array}$} \\
\hline
\end{tabular}

Ao analisar os vieses médios (Tabela 4), nota-se, para o modelo 1, que as predições de NUL superestimaram as concentrações observadas em, aproximadamente, 
$22 \%$ ou em 2,93 mg/dL. Por sua vez, o modelo 2 subestimou os valores de NUL em, aproximadamente, $13 \%(-1,72 \mathrm{mg} / \mathrm{dL})$ e o modelo 3 , em $1,5 \%(-0,21 \mathrm{mg} / \mathrm{dL})$. Observase que as médias de vieses dos 3 modelos diferiram de $0(\mathrm{P}<0,01)$, mostrando falta de acurácia para todos. No entanto, as medidas de acurácia dos modelos, representadas pelas médias dos vieses, apresentaram diferenças entre si $(\mathrm{P}<0,05)$, apontando que o modelo 3 é o mais acurado por apresentar o menor viés médio $(-0,21)$, seguido pelo modelo 2 (-1,72) e pelo modelo 1 (2,93), que se apresentou como o menos acurado (Tabela 4).

Quanto à precisão, nota-se que os erros residuais dos três modelos diferiram entre si, de modo que o mais preciso é o modelo $2(4,90)$ e o menos preciso é o modelo 1 (5,99). As RQMEP foram de 6,66, 5,19 e 5,25 mg/dL, para os modelos 1, 2 e 3, respectivamente. Assim, o modelo 3, apesar de mais acurado, é medianamente preciso, apresentando erro residual de 5,24 (Tabela 4). Por outro lado, o modelo 1 foi o menos acurado e o menos preciso.

Pela regressão do viés (NUL predito - NUL observado) versus NUL observado (Tabela 4), observam-se vieses lineares (coeficientes angulares das retas) negativos $(\mathrm{P}=0,0001)$ de $-0,8408,-0,8868$ e $-1,0835 \mathrm{mg} / \mathrm{dL}$, para os modelos 1,2 e 3 , respectivamente. Essa constatação indica que o viés (predito - observado) foi menor quanto maior o valor observado de NUL. Nota-se, ainda, que os vieses lineares dos três modelos diferiram entre si $(\mathrm{P}<0,05)$, o que pode ser observado na Figura 2. 


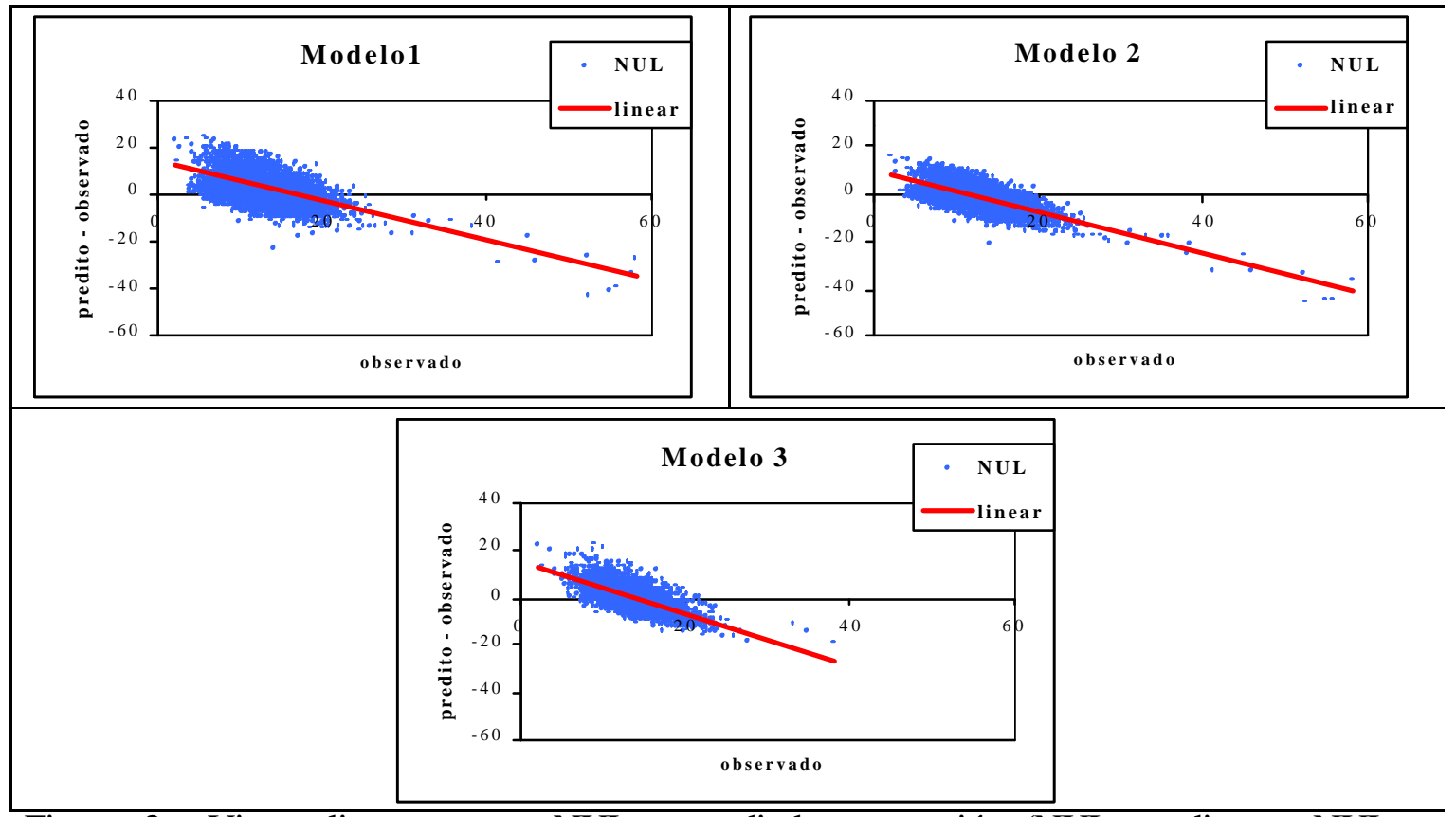

Figura 2- Vieses lineares para NUL, regredindo-se o viés (NUL predito - NUL observado) versus NUL observado para os modelos 1,2 e 3, usando o consumo real médio mensal do rebanho para estimar o consumo de matéria seca individual

A avaliação de robustez dos 3 modelos pode ser observada na Tabela 5. Observa-se que os 3 modelos foram influenciados por quase todas as variáveis estudadas, uma vez que os coeficientes angulares das retas dos vieses dos modelos versus essas variáveis diferiram de $0(\mathrm{P}<0,05)$. Porém, os modelos 1 e 2 não foram afetados pela época de parição e época do ano, fato reforçado pelos baixíssimos coeficientes angulares das retas de regressão dos vieses dos modelos versus essas duas variáveis. Visualmente, pelo $\mathrm{R}^{2}$, observa-se que a produção de leite apresentou o maior coeficiente, indicando que essa variável é a que mais explica as variações dos modelos e que neles poderia ser incluída. Observa-se, ainda, que os coeficientes angulares dos vieses dos modelos 2 e 3 versus a produção de leite não diferiram entre si, mas diferiram do modelo 1 . 
Tabela 5. Avaliação de robustez (slope, $\mathrm{R}^{2}$ e probabilidade) para os modelos 1,2 e 3 , incluindo outras variáveis, usando o consumo real médio mensal do rebanho para estimar o consumo de matéria seca individual

\begin{tabular}{|c|c|c|c|c|}
\hline Variáveis estudadas & & Modelo 1 & Modelo 2 & Modelo 3 \\
\hline Número de lactação & $\begin{array}{c}\text { Slope } \\
\left.\mathrm{R}^{2} \text { (Prob. }\right)^{4}\end{array}$ & $\begin{array}{c}-0,5645 \mathrm{~A} \\
0,0194(<0,0001)\end{array}$ & $\begin{array}{c}-0,4736 \mathrm{~A} \\
0,0204(<0,0001)\end{array}$ & $\begin{array}{c}-1,2353 \mathrm{~B} \\
0,1109(<0,0001)\end{array}$ \\
\hline Dias em lactação & $\begin{array}{c}\text { Slope } \\
\mathrm{R}^{2} \text { (Prob.) }\end{array}$ & $\begin{array}{c}0,0130 \mathrm{~A} \\
0,0767(<0,0001)\end{array}$ & $\begin{array}{c}0,0108 \mathrm{~B} \\
0,0785(<0,0001)\end{array}$ & $\begin{array}{c}0,0043 \mathrm{C} \\
0,0104(<0,0001)\end{array}$ \\
\hline Peso corporal (kg) & $\begin{array}{c}\text { Slope } \\
\mathrm{R}^{2} \text { (Prob.) }\end{array}$ & $\begin{array}{c}0,0036 \mathrm{~A} \\
0,0037(<0,0001)\end{array}$ & $\begin{array}{c}0,0030 \mathrm{~A} \\
0,0038(<0,0001)\end{array}$ & $\begin{array}{c}-0,0186 \mathrm{~B} \\
0,1178(<0,0001)\end{array}$ \\
\hline Produção de leite (kg/dia) & $\begin{array}{c}\text { Slope } \\
\mathrm{R}^{2} \text { (Prob.) }\end{array}$ & $\begin{array}{c}-0,3781 \mathrm{~B} \\
0,3410(<0,0001)\end{array}$ & $\begin{array}{c}-0,2968 \mathrm{~A} \\
0,3134(<0,0001)\end{array}$ & $\begin{array}{c}-0,2989 \mathrm{~A} \\
0,2691(<0,0001)\end{array}$ \\
\hline Gordura do leite (\%) & $\begin{array}{c}\text { Slope } \\
\mathrm{R}^{2} \text { (Prob.) }\end{array}$ & $\begin{array}{c}1,9554 \mathrm{~A} \\
0,0754(<0,0001)\end{array}$ & $\begin{array}{c}1,4900 \mathrm{~B} \\
0,0653(<0,0001)\end{array}$ & $\begin{array}{c}1,2838 \mathrm{~B} \\
0,0405(<0,0001)\end{array}$ \\
\hline Proteína do leite (\%) & $\begin{array}{c}\text { Slope } \\
\mathrm{R}^{2} \text { (Prob.) }\end{array}$ & $\begin{array}{c}3,1258 \mathrm{~A} \\
0,0360(<0,0001)\end{array}$ & $\begin{array}{c}2,8595 \mathrm{~A} \\
0,0449(<0,0001)\end{array}$ & $\begin{array}{c}1,3620 \mathrm{~B} \\
0,0082(<0,0001)\end{array}$ \\
\hline Relação gordura/proteína & $\begin{array}{c}\text { Slope } \\
\mathrm{R}^{2} \text { (Prob.) }\end{array}$ & $\begin{array}{c}4,2506 \mathrm{~A} \\
0,0365(<0,0001)\end{array}$ & $\begin{array}{c}2,9695 \mathrm{~B} \\
0,0266(<0,0001)\end{array}$ & $\begin{array}{c}3,4654 \mathrm{~B} \\
0,0285(<0,0001)\end{array}$ \\
\hline Lactose $(\%)$ & $\begin{array}{c}\text { Slope } \\
\mathrm{R}^{2} \text { (Prob.) }\end{array}$ & $\begin{array}{c}-2,7204 \mathrm{C} \\
0,0251(<0,0001)\end{array}$ & $\begin{array}{c}-1,7986 \mathrm{~B} \\
0,0163(<0,0001)\end{array}$ & $\begin{array}{c}1,0165 \mathrm{~A} \\
0,0039(<0,0001)\end{array}$ \\
\hline Sólidos totais do leite $(\%)$ & $\begin{array}{c}\text { Slope } \\
\mathrm{R}^{2} \text { (Prob.) }\end{array}$ & $\begin{array}{c}1,3732 \mathrm{~A} \\
0,0604(<0,0001)\end{array}$ & $\begin{array}{c}1,1331 \mathrm{~B} \\
0,0613(<0,0001)\end{array}$ & $\begin{array}{c}1,1053 \mathrm{~B} \\
0,0503(<0,0001)\end{array}$ \\
\hline $\operatorname{LCCS}^{1}$ & $\begin{array}{c}\text { Slope } \\
\mathrm{R}^{2} \text { (Prob.) }\end{array}$ & $\begin{array}{c}0,6640 \mathrm{~A} \\
0,0277(<0,0001)\end{array}$ & $\begin{array}{c}0,5618 \mathrm{~A} \\
0,0295(<0,0001)\end{array}$ & $\begin{array}{c}0,2827 \mathrm{~B} \\
0,0066(<0,0001)\end{array}$ \\
\hline Época de parição & $\begin{array}{c}\text { Slope } \\
\mathrm{R}^{2} \text { (Prob.) }\end{array}$ & $\begin{array}{c}-0,0322 \mathrm{~A} \\
0,000007(0,8010)\end{array}$ & $\begin{array}{c}0,0227 \mathrm{~A} \\
0,000005(0,8283)\end{array}$ & $\begin{array}{c}0,3174 \mathrm{~A} \\
0,000892(0,0396)\end{array}$ \\
\hline Época do ano & $\begin{array}{c}\text { Slope } \\
\mathrm{R}^{2} \text { (Prob.) }\end{array}$ & $\begin{array}{c}0,2097 \mathrm{~A} \\
0,000307(0,0998)\end{array}$ & $\begin{array}{c}0,1999 \mathrm{~A} \\
0,000416(0,0553)\end{array}$ & $\begin{array}{c}-0,6230 \mathrm{~B} \\
0,003371(<0,0001)\end{array}$ \\
\hline \multicolumn{5}{|c|}{$\begin{array}{l}{ }^{1} \text { logaritmo natural da }(\mathrm{CCS}+1) \text {. } \\
{ }^{2} \text { coeficiente angular da reta } \mathrm{y}=\mathrm{a}+\mathrm{bX} \text {, regredindo-se o viés (NUL predito }-\mathrm{NUL} \text { observado) versus } \\
\text { variáveis. } \\
\text { va comparação entre inclinações das retas, em que letras diferentes na mesma linha diferem entre si pela } \\
\text { metodologia de comparação de retas (análise de variância) }(\mathrm{P}<0,05) \text {. } \\
{ }^{3} \text { coeficiente de determinação e probabilidade de a análise de variância indicar existência ou não de } \\
\text { inclinação da reta (teste } \mathrm{F}) \text {. }\end{array}$} \\
\hline
\end{tabular}

De acordo com Jonker et al. (1999), a produção de leite direciona as exigências de nitrogênio nas vacas leiteiras em lactação alimentadas de acordo com o NRC (1989). À medida que a produção de leite aumenta, as concentrações preditas de NUL aumentam linearmente por causa da maior ingestão e excreção de nitrogênio. Subsequientemente, as concentrações-alvo de NUL são extremamente sensíveis às 
mudanças na produção de leite. Jonker et al. (1999) ainda reportaram que a concentração lactacional média de NUL para seu modelo foi mais sensível ao plano de alimentação relativo às exigências e à produção de leite e menos ao peso corporal e número de lactações.

A concentração de gordura, proteína, lactose e sólidos totais e a relação gordura/proteína apresentaram os maiores coeficientes angulares, apesar de apresentarem baixos $\mathrm{R}^{2}$. Segundo Jonker et al. (1999), a sensibilidade das concentrações-alvo de NUL a mudanças nas percentagens de gordura e proteína ocorre por duas razões. Para as exigências de ingestão de nitrogênio preditas pelo NRC (1989), a percentagem de gordura (junto com o volume de leite) direciona as exigências de nitrogênio para lactação (NRC, 1989).

A predição do modelo para excreção de nitrogênio urinário usa o nitrogênio total do leite e afeta as concentrações-alvo de NUL. Ao se aumentar a concentração de proteína do leite, são reduzidas as concentrações-alvo de NUL, pois uma quantidade maior de nitrogênio ingerido é direcionada para a proteína do leite. Entretanto, Trevaskis \& Fulkerson (1999) mostraram, em seu estudo, que o mérito genético, o número de lactações e o conteúdo de proteína do leite explicaram uma pequena parte da variação individual na concentração de NUL e, assim, não foram úteis para suas predições.

\subsubsection{Validação dos modelos usando o consumo real médio mensal de matéria seca do rebanho}

Os resultados das avaliações de acurácia e precisão para os 3 modelos testados, utilizando-se o consumo real médio mensal de matéria seca do rebanho, estão apresentados na Tabela 6 . 
Tabela 6. Número amostral, viés médio (acurácia), erro residual (precisão), raiz quadrada média do erro de predição (RQMEP) e coeficiente de determinação $\left(\mathrm{R}^{2}\right)$, para os modelos 1,2 e 3, e regressão entre viés e NUL observado, usando os dados de consumo real médio mensal de matéria seca do rebanho

\begin{tabular}{|c|c|c|c|}
\hline & Modelo 1 & Modelo 2 & Modelo 3 \\
\hline $\mathrm{N}$ & 16 & 16 & 10 \\
\hline NUL observado & 13,13 & 13,13 & 13,83 \\
\hline NUL predito & 15,73 & 11,19 & 12,95 \\
\hline Viés médio ${ }^{1,2}$ & $2,60 \mathrm{~A} *$ & $-1,95 \mathrm{~B} *$ & $-0,89 \mathrm{~B}$ \\
\hline Erro residual $^{3}$ & $3,72 \mathrm{~A}$ & $2,68 \mathrm{~A}$ & $2,64 \mathrm{~A}$ \\
\hline $\mathrm{RQMEP}^{4}$ & 4,45 & 3,25 & 2,66 \\
\hline \multirow[t]{2}{*}{$\mathrm{R}^{2}$} & 0,2455 & 0,2453 & 0,000333 \\
\hline & \multicolumn{3}{|c|}{ Regressão entre viés e NUL observado 5} \\
\hline Viés linear ${ }^{6,7}$ & $0,0784 \mathrm{~A}$ & $-0,2339 \mathrm{~A}$ & $-1,0229 \mathrm{~A}$ \\
\hline $\mathrm{R}^{2}$ (Probabilidade) $^{8}$ & $0,0017(0,8789)$ & $0,0294(0,5255)$ & $0,3992(0,0500)$ \\
\hline \multicolumn{4}{|c|}{$\begin{array}{l}{ }^{7} \text { Médias na mesma linha, seguidas de diferentes letras, são diferentes }(\mathrm{P}<0,05) \text { pelo teste de Tukey. } \\
{ }^{2} \text { Probabilidade do teste } T \text { para média }=0 \text { * Média diferente de } 0 \text { (zero) a } 5 \% \text {. } \\
{ }^{3} \text { Erros residuais na mesma linha, seguidos de diferentes letras, são diferentes pelo teste de Hartley } \\
(\mathrm{P}<0,05) \text {, realizado } 2 \text { a } 2 \text {. } \\
{ }^{4} \text { Raiz quadrada média do erro de predição. } \\
{ }^{5} \text { Regressão entre (NUL predito - NUL observado) e NUL observado. } \\
{ }^{6} \text { Coeficiente angular da regressão entre (NUL predito - NUL observado) e NUL observado. } \\
{ }^{7} \text { Médias na mesma linha, seguidas de diferentes letras, são diferentes }(\mathrm{P}<0,05) \text { pela metodologia de } \\
\text { comparação de retas (análise de variância). } \\
{ }^{8} \text { Coeficiente de determinação e probabilidade da existência ou não de inclinação da reta (teste F). }\end{array}$} \\
\hline
\end{tabular}

Ao analisar os vieses médios (Tabela 6), observa-se que as predições do modelo 1 superestimaram as concentrações de NUL em, aproximadamente, 20\% ou em $2,60 \mathrm{mg} / \mathrm{dL}$. Por sua vez, o modelo 2 subestimou os valores de NUL em, aproximadamente, $15 \%(-1,95 \mathrm{mg} / \mathrm{dL})$ e o modelo 3 , em, aproximadamente, $6 \%(-0,89$ $\mathrm{mg} / \mathrm{dL})$. Nota-se que as médias de vieses dos modelos 1 e 2 diferiram de $0(\mathrm{P}<0,05)$, mostrando falta de acurácia, enquanto, para o modelo 3, a média dos vieses não diferiu de 0 , indicando que tal modelo é acurado. No entanto, as medidas de acurácia dos modelos 2 e 3, com relação à média dos vieses, não apresentaram diferenças entre si $(\mathrm{P}<0,05)$, mas foram diferentes do modelo 1 (Tabela 6). Desse modo, nota-se que o 
modelo 3 é o mais acurado por apresentar o menor viés médio $(-0,89)$ e por não diferir de 0.

Quanto à precisão, nota-se que os erros residuais dos 3 modelos não diferiram entre si, apesar de o modelo 3 apresentar, numericamente, o menor erro residual, aparentando ser mais preciso. As RQMEP encontradas para os modelos 1, 2 e 3 foram de 4,45, 3,25 e 2,66 mg/dL, respectivamente (Tabela 6). Assim, o modelo 3 apresenta-se mais acurado e, numericamente, mais preciso. Por outro lado, os modelos 1 e 2 não se apresentaram adequados para essa situação. Cabe ressaltar que o número amostral é bastante reduzido, por se tratar de dados médios mensais do rebanho e não mais de dados individuais.

Pela regressão do viés (NUL predito - NUL observado) versus NUL observado, não se observam vieses lineares (coeficientes angulares) para nenhum dos três modelos estudados, que também não diferiram entre si (Tabela 2 e Figura 3). Desse modo, o viés (predito - observado) não se altera quanto maior ou menor for o valor observado de NUL. 


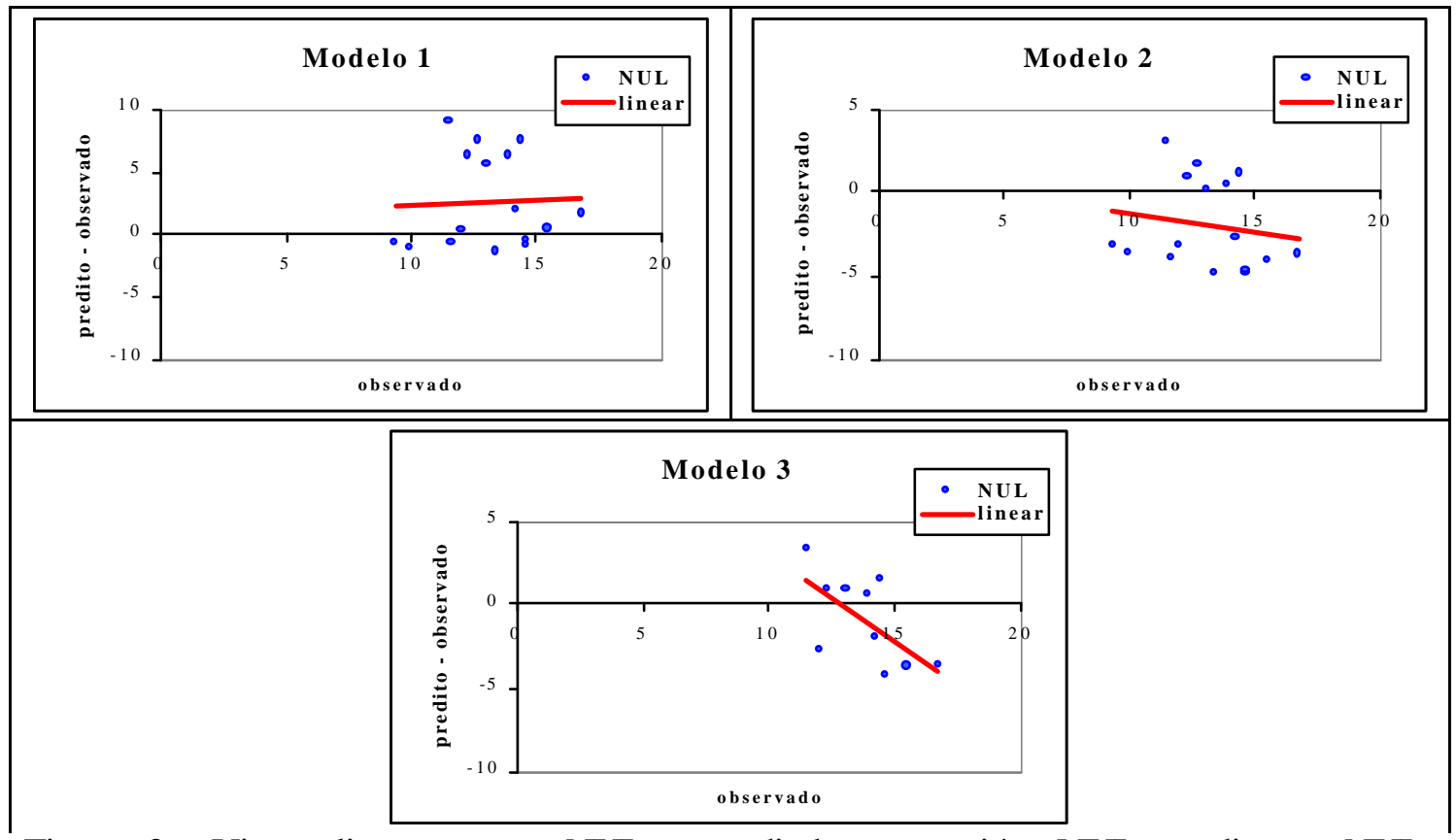

Figura 3- Vieses lineares para NUL, regredindo-se o viés (NUL predito - NUL observado) versus NUL observado, para os modelos 1,2 e 3, usando o consumo de matéria seca médio do rebanho

A avaliação de robustez dos 3 modelos pode ser observada na Tabela 7.

Diferentemente dos estudos anteriores, com os outros consumos de matéria seca estudados, em que os três modelos foram influenciados por quase todas as variáveis estudadas, para esses dados com CMS do rebanho, observa-se que apenas o número de dias em lactação e a concentração de gordura influenciaram diferentemente os modelos. Essa afirmação pode ser feita ao se notar que os coeficientes angulares das retas dos vieses dos modelos 1 e 2 versus a variável DEL diferiram de $0(\mathrm{P}<0,05)$, assim como os dos vieses do modelo 1 versus a concentração de gordura.

Os coeficientes angulares das retas de regressão dos vieses dos 3 modelos versus todas variáveis estudadas não diferiram entre si (Tabela 7). Os baixos coeficientes angulares das retas ("slopes”) de regressão dos vieses dos modelos versus a produção de leite, aliados aos mais baixos coeficientes de determinação e às altas probabilidades, que indicam inexistência de inclinação da reta, apontam que tal variável foi a que menos influenciou os modelos estudados. 
Tabela 7. Avaliação de robustez (slope, $\mathrm{R}^{2}$ e probabilidade) para os modelos 1,2 e 3 , incluindo outras variáveis, usando o consumo de matéria seca médio do rebanho

\begin{tabular}{|c|c|c|c|c|}
\hline Variáveis estudadas & & Modelo 1 & Modelo 2 & Modelo 3 \\
\hline Número de lactação & $\begin{array}{c}\text { Slope }{ }^{2,3} \\
\mathrm{R}^{2} \text { (Prob.) }^{4}\end{array}$ & $\begin{array}{c}-35,0508 \mathrm{~A} \\
0,0625(0,3505)\end{array}$ & $\begin{array}{c}-23,7813 \mathrm{~A} \\
0,05533(0,3805)\end{array}$ & $\begin{array}{c}-5,7984 \mathrm{~A} \\
0,0040(0,8621)\end{array}$ \\
\hline Dias em lactação & $\begin{array}{c}\text { Slope } \\
\mathrm{R}^{2} \text { (Prob.) }\end{array}$ & $\begin{array}{c}0,0944 \mathrm{~A} \\
0,3374(0,0183)\end{array}$ & $\begin{array}{c}0,0708 \mathrm{~A} \\
0,3656(0,0131)\end{array}$ & $\begin{array}{c}0,0582 \mathrm{~A} \\
0,3862(0,0551)\end{array}$ \\
\hline Peso corporal (kg) & $\begin{array}{c}\text { Slope } \\
\mathrm{R}^{2} \text { (Prob.) }\end{array}$ & $\begin{array}{c}0,1470 \mathrm{~A} \\
0,3765(0,0592)\end{array}$ & $\begin{array}{c}0,1039 \mathrm{~A} \\
0,3042(0,0984)\end{array}$ & $\begin{array}{c}0,0886 \mathrm{~A} \\
0,2358(0,1548)\end{array}$ \\
\hline Produção de leite (kg/dia) & $\begin{array}{c}\text { Slope } \\
\mathrm{R}^{2} \text { (Prob.) }\end{array}$ & $\begin{array}{c}0,0071 \mathrm{~A} \\
0,000014(0,9889)\end{array}$ & $\begin{array}{c}-0,1217 \mathrm{~A} \\
0,008230(0,7383)\end{array}$ & $\begin{array}{c}-0,3698 \mathrm{~A} \\
0,0802(0,4277)\end{array}$ \\
\hline Gordura do leite (\%) & $\begin{array}{c}\text { Slope } \\
\mathrm{R}^{2} \text { (Prob.) }\end{array}$ & $\begin{array}{c}7,6809 \text { A } \\
0,2646(0,0415)\end{array}$ & $\begin{array}{c}4,4810 \mathrm{~A} \\
0,1733(0,1088)\end{array}$ & $\begin{array}{c}1,6353 \mathrm{~A} \\
0,0213(0,6874)\end{array}$ \\
\hline Proteína do leite (\%) & $\begin{array}{c}\text { Slope } \\
\mathrm{R}^{2} \text { (Prob.) }\end{array}$ & $\begin{array}{c}-6,5519 \text { A } \\
0,0196(0,6054)\end{array}$ & $\begin{array}{c}-4,2196 \mathrm{~A} \\
0,01561(0,6447)\end{array}$ & $\begin{array}{c}0,3459 \text { A } \\
0,000099(0,9782)\end{array}$ \\
\hline Relação gordura/proteína & $\begin{array}{c}\text { Slope } \\
\mathrm{R}^{2} \text { (Prob.) }\end{array}$ & $\begin{array}{c}20,5422 \mathrm{~A} \\
0,2368(0,0560)\end{array}$ & $\begin{array}{c}12,1656 \mathrm{~A} \\
0,1598(0,1250)\end{array}$ & $\begin{array}{c}5,2826 \mathrm{~A} \\
0,0225(0,6789)\end{array}$ \\
\hline Lactose $(\%)$ & $\begin{array}{c}\text { Slope } \\
\mathrm{R}^{2} \text { (Prob.) }\end{array}$ & $\begin{array}{c}-10,2121 \mathrm{~A} \\
0,1279(0,1738)\end{array}$ & $\begin{array}{c}-6,2550 \mathrm{~A} \\
0,0923(0,2525)\end{array}$ & $\begin{array}{c}-5,5491 \mathrm{~A} \\
0,0489(0,5394)\end{array}$ \\
\hline Sólidos totais do leite $(\%)$ & $\begin{array}{c}\text { Slope } \\
\mathrm{R}^{2} \text { (Prob.) }\end{array}$ & $\begin{array}{c}4,2816 \mathrm{~A} \\
0,1038(0,2236)\end{array}$ & $\begin{array}{c}2,4683 \mathrm{~A} \\
0,0664(0,3354)\end{array}$ & $\begin{array}{c}0,8796 \mathrm{~A} \\
0,0105(0,7779)\end{array}$ \\
\hline $\operatorname{LCCS}^{1}$ & $\begin{array}{c}\text { Slope } \\
\mathrm{R}^{2} \text { (Prob.) }\end{array}$ & $\begin{array}{c}-2,1529 \mathrm{~A} \\
0,0145(0,6565)\end{array}$ & $\begin{array}{c}-1,6959 \mathrm{~A} \\
0,0174(0,6267)\end{array}$ & $\begin{array}{c}-1,2248 \text { A } \\
0,0090(0,7938)\end{array}$ \\
\hline Época do ano & $\begin{array}{c}\text { Slope } \\
\mathrm{R}^{2} \text { (Prob.) }\end{array}$ & $\begin{array}{c}0,2488 \text { A } \\
0,0012(0,8991)\end{array}$ & $\begin{array}{c}0,2738 \mathrm{~A} \\
0,0028(0,8464)\end{array}$ & $\begin{array}{c}0,0217 \mathrm{~A} \\
0,000018(0,9907)\end{array}$ \\
\hline
\end{tabular}

${ }^{\mathrm{T}}$ logaritmo natural da (CCS+1).

${ }^{2}$ coeficiente angular da reta $\mathrm{y}=\mathrm{a}+\mathrm{bX}$, regredindo-se o viés (NUL predito - NUL observado) versus variáveis.

${ }^{3}$ comparação entre coeficientes angulares, em que letras diferentes na mesma linha diferem entre si pela metodologia de comparação de retas (análise de variância) $(\mathrm{P}<0,05)$.

${ }^{4}$ coeficiente de determinação e probabilidade de a análise de variância indicar existência ou não de inclinação da reta (teste F).

Vários outros trabalhos (Bruckental et al., 1980; Gustafsson et al, 1987; Emanuelson et al., 1993; Carlsson et al, 1995) indicaram que a concentração de NUL foi influenciada pelo número de dias em lactação, sendo menor no início da lactação. Alguns fatores podem exercer efeitos para reduzir a concentração de uréia no início da lactação (Carlsson et al., 1995). Entre eles, estão a inabilidade das vacas em ingerir alimento suficiente no início da lactação, o que pode induzir - ou ser o resultado de uma função subótima da microbiota ruminal e o risco de distúrbios metabólicos durante 
o primeiro mês de lactação. Contraditoriamente, a proposta de Kaufmann (1982) é que, nesse período, deveria se esperar alta concentração de NUL, em virtude da dificuldade que as vacas de alta produção têm de satisfazer suas exigências energéticas, levando à utilização de proteína corporal. Entretanto, Trevaskis \& Fulkerson (1999) não encontraram efeitos de estágio de lactação e peso corporal sobre as predições de NUL.

Em uma discussão geral, Kohn et al. (2002), ao usarem dados antigos, encontraram RQMEP de 4,3, 4,9 e 4,1, para os modelos 1, 2 e 3, respectivamente, enquanto, ao usarem dados novos, as RQMEP foram de 6,1, 2,9 e 2,6 mg/dL, respectivamente. Nota-se que com os dados novos usados nos modelos mais recentes (2 e 3), a RQMEP diminuiu bastante, enquanto, para o modelo antigo (1), a RQMEP piorou. Em comparação aos resultados de Kohn et al. (2002) (usando dados novos em sua validação), observa-se que a RQMEP do presente estudo só foi melhor para o modelo $1(4,45 \mathrm{mg} / \mathrm{dL})$ e semelhante para o modelo $3(2,66 \mathrm{mg} / \mathrm{dL})$ quando foi usado o consumo real médio mensal de MS do rebanho (Tabela 6). Mas cabe salientar que o número amostral usado nesse último foi bastante reduzido, por se tratar de dados mensais do rebanho e não de dados individuais dos animais.

\subsection{Conclusões}

Considerando os três métodos de se estimar o consumo de matéria seca dos animais, conclui-se que os três modelos de predição de nitrogênio uréico no leite diferem entre si quanto à acurácia, precisão e robustez, apresentando uso questionável quando o objetivo for predizer NUL para vacas leiteiras ou predizer a excreção de nitrogênio urinário nas condições de campo estudadas. 


\section{CONCLUSÕES GERAIS}

A refrigeração e o congelamento foram as melhores opções para o armazenamento das amostras de leite, devendo ser analisadas até 3 dias após sua coleta.

Dentre os fatores não-nutricionais, a produção de leite e a concentração de proteína do leite foram os fatores que mais afetaram as concentrações de nitrogênio uréico no leite, podendo auxiliar a utilização de NUL como indicador de avaliação nutricional de vacas em lactação.

As concentrações de nitrogênio uréico no leite apresentaram comportamento semelhante à curva de lactação, diferindo entre as $1^{\mathrm{a}}, 2^{\mathrm{a}}, 3^{\mathrm{a}}$ e $4^{\mathrm{a}}-5^{\mathrm{a}}$ lactações, sendo influenciadas pela época de parição.

Os três modelos de predição de nitrogênio uréico no leite diferem entre si quanto à acurácia, precisão e robustez, apresentando uso questionável quando o objetivo for predizer NUL para vacas leiteiras nas condições de campo estudadas. 


\section{REFERÊNCIAS BIBLIOGRÁFICAS}

ALI, T.E.; SCHAEFFER, L.R. Accounting for covariances among test day milk yields in dairy cows. Canadian Journal of Animal Science, v.67, n.3, p.637-644, 1987.

ANDERSSON, R.E. Microbial lipolysis at low temperatures. Applied Environmental Microbiology, v.39, p.36-40, 1980.

ARUNVIPAS, P.; DOHOO, I.; VANLEEUWEN, J.; LEGER, E.; KEEFE, G. The effect of non-nutritional factors on milk urea nitrogen levels in Ayrshire dairy cows. Journal of Dairy Science, v.85, suppl.1, p.320, 2002.

ASHWORTH, U.S.; SEALS, R.; ERB, R.E. An improved procedure for the determination of milk proteins by dye binding. Journal of Dairy Science, v. 43, p.614-623, 1960.

BARKEMA, H.W.; VAN DER SCHANS, J.; SCHUKKEN, Y.H.; DE GEE, A.L.W.; LAM, T.J.G.M.; BENEDICTUS, G. Effect of freezing on somatic cell count of quarter milk samples as determined by a Fossomatic electronic cell counter. Journal of Dairy Science, v.80, n.2, p.422-426, 1997.

BATRA, T.R. Comparison of two mathematical models in fitting lactation curves for pureline and crossline dairy cows. Canadian Journal of Animal Science, v.66, n.2, p.405-414, 1986.

BENTLEY INSTRUMENTS. Bentley 2000: operator's manual. Chaska, 1995a. 77p.

BENTLEY INSTRUMENTS. Somacount 300: operator's manual. Chaska, 1995b. $12 \mathrm{p}$.

BENTLEY INSTRUMENTS. Chemspeck 150: user's guide. Chaska, 1998. 17p.

BERTRAND, J.A. Influence if shipping container, preservative, and breed on analysis of milk components of shipped samples. Journal of Dairy Science, v.79, n.1, p.145-148, 1996.

BIBBY, J.; TOUTENBURG, $\mathrm{H}$. Prediction and improved estimation in linear models. London: John Wiley, 1977. 188p.

BIGGS, D.A. Milk analysis with the infrared milk analyzer. Journal of Dairy Science, v.50, n.5, p.799-803, 1967.

BLAXTER, K.L. The energy metabolism of ruminants. London: Hutchinson, 1962. $329 \mathrm{p}$. 
BRODERICK, G.A.; CLAYTON, M.K. A statistical evaluation of animal and nutritional factors influencing concentration of milk urea nitrogen. Journal of Dairy Science, v.80, n.11, p.2964-2971, 1997.

BRUCKENTAL, I.; OLDHAM, J.D.; SUTTON, J.D. Glucose and urea kinetics in early lactation. British Journal of Nutrition, v.44, p.33-45, 1980.

BRUCKENTAL, I.; DRORI, D.; KAIM, M.; LEHRER, H.; FOLMAN, Y. Effects of source and level of protein on milk yield and reproductive performance of highproducing primiparous and multiparous dairy cows. Animal Production, v.48, p.319-329, 1989.

BUTLER, W.R.; CHERNEY, D.J.R.; ELROD, C.C. Milk urea nitrogen: Field trial results on conception rates and dietary inputs. In: THE CORNELL NUTRITION CONFERENCE FOR FEED MANUFACTURES, Ithaca, 1995. Proceedings. Ithaca: Cornell University Press, 1995. p.89-94

CANFIELD, R.W.; SNIFFEN, C.J.; BUTLER, W.R. Effects of excess degradable protein on postpartum reproduction and energy balance in dairy cattle. Journal of Dairy Science, v.73, n.9, p.2342-2349, 1990.

CANNAS, A.; PES, A.; MANCUSO, R.; VODRET, B.; NUDDA, A. Effect of dietary energy and protein concentration on the concentration of milk urea nitrogen in dairy ewes. Journal of Dairy Science, v.81, n.2, p.499-508, 1998.

CARLSSON, J.; BERGSTRÖM, J. The diurnal variation of urea in cow's milk and how milk fat content, storage and preservation affects analysis by a flow injection technique. Acta Veterinaria Scandinavica, v.35, n.1, p.67-77, 1994.

CARLSSON, J.; PEHRSON, B. The relationships between seasonal variations in the concentration of urea in bulk milk and the production and fertility of dairy herds. Journal of Veterinary Medical Association, v.40, p.205-212, 1993.

CARLSSON, J.; PEHRSON, B. The influence of the dietary balance between energy and protein on milk urea concentration. Experimental trials assessed by two different protein evaluation systems. Acta Veterinaria Scandinavica, v.35, n.2, p.193-205, 1994.

CARLSSON, J.; BERGSTRÖM, J.; PEHRSON, B. Variations with breed, age, season, yield, stage of lactation and herd in the concentration of urea in bulk milk and individual cow's milk. Acta Veterinaria Scandinavica, v.36, n.2, p.245-254, 1995.

CARROLL, D.J.; BARTON, B.A.; ANDERSON, G.W.; SMITH, R.D. Influence of protein intake and feeding strategy on reproductive performance of dairy cows. Journal of Dairy Science, v.71, n.12, p.3470-3481, 1988.

CELESTINO, E.L.; IYER, M.; ROGINSKI, H. The effects of refrigerated storage on the quality of raw milk. Australian Journal of Dairy Technology, v.51, p.59-63, 1996. 
CHALUPA, W. Discussion of protein symposium. Journal of Dairy Science, v.71, p.3470-3481, 1984.

CHASE, L.F. Environmental considerations in developing dairy rations. In: THE CORNELL NUTRITION CONFERENCE, Rochester, 1994. Proceedings. Ithaca: Cornell University Press, 1994. p.56-62

CHAVEZ, E.C.; TOMASZEWSKI, D.C.; CHERBONNIER, D.C.; RUVUNA, F. Evaluation of five alternative milk preservatives for the DHI System. Journal of Dairy Science, v.74, suppl.1, p.233, 1991. Abstr.

CLARKE, T.; EVANS, M.E.; HEPWORTH, G.; MOATE, P.J.; STEWART, J.A. Mordant factors that affect the fluorescence and counting of somatic cells by instruments. Journal of Dairy Research, v.62, p.373-394, 1995.

CONGLETON, W.R.; EVERETT, R.W. Error and bias in using the incomplete gamma function to describe lactation curves. Journal of Dairy Science, v.63, n.1, p.101$108,1980$.

COSTA, C.N.; MILAGRES, J.C.; CASTRO, A.C.G.; GARCIA, J.A. Efeitos da estação e idade ao parto sobre a curva de lactação de vacas da raça Holandesa. Revista da Sociedade Brasileira de Zootecnia. v.11, n.2, p.320-330, 1982.

DARLING, D.; BUTCHER, D.W. Milk fat globule membrane in homogenized cream. Journal of Dairy Research, v.45, p.197-208, 1978.

DEPETERS, E.J.; FERGUSON, J.D. Nonprotein nitrogen and protein distribution in the milk of cows. Journal of Dairy Science, v.75, p.3192-3209, 1992.

DIJKSTRA, J.; FRANCE, J.; DAVIES, D.R. Different mathematical approaches to estimating microbial protein supply in ruminants. Journal of Dairy Science, v.81, n.12, p.3370-3384, 1998.

DUNLAP, T.F.; KOHN, R.A.; DAHL, G.E.; ERDMAN, R.A.; VARNER, M. The impact of bovine somatotropin, three times daily milking or extended photoperiod on nitrogen flows from dairy farms. Journal of Dairy Science, v.83, p.968-976, 2000.

EDWARDS, J.S.; BARTLEY, E.E.; DAYTON, A.D. Effects of dietary protein concentrations on lactating cows. Journal of Dairy Science, v.63, n.2, p.243-248, 1980.

EICHER, R.; BOUCHARD, E.; TREMBLAY, A. Cow level sampling factors affecting analysis and interpretation of milk urea concentrations in 2 dairy herds. Canadian Veterinary Journal, v.40, n.7, p.487-492, 1999.

ELROD, C.C.; BUTLER, W.R. Nutrition and reproduction relationships in dairy cattle. In: THE CORNELL NUTRITION CONFERENCE, Ithaca, 1991. Proceedings. Ithaca: Cornell University Press, 1991. p.73. 
EMANUELSON, M.; AHLIN, K.A.; WIKTORSSON, H. Long term feeding of rapeseed meal and full-fat rapeseed of double low cultivars to dairy cows. Livestock Production Science, v.33, p.199-214, 1993.

FARRANT, J. Freeze-thaw injury in living cells. International Journal of Refrigeration, v.3, p.191, 1980.

FERGUSON, J.D. Milk urea nitrogen fttp://gandalf.dhia.psu.edu/mun/mun/ans, 1997. (01 jul. 2000).

FERGUSON, J.D.; CHALUPA, W. Impact of protein nutrition on reproduction in dairy cows. Journal of Dairy Science, v.72, n.3, p.746-766, 1989.

FERGUSON, J.D.; THOMSEN, N.; SLESSER, D.; BURRIS, D. Pennsylvania DHIA milk urea testing. Journal of Dairy Science, v.80, suppl.1, p.161, 1997.

FOLMAN, Y.; NEUMARK, H.; KAIM, M.; KAUFMANN, W. Performance, rumen and blood metabolites in high-yielding cows fed varying protein percents and protected soybean. Journal of Dairy Science, v.64, n.5, p.759-768, 1981.

GODDEN, S.M.; LISSEMORE, K.D.; KELTON, D.F.; LESLIE, K.E.; WALTON, J.S.; LUMSDEN, J.H. Factors associated with milk urea concentrations in Ontario dairy cows. Journal of Dairy Science, v.84, n.1, p.107-114, 2001a.

GODDEN, S.M.; LISSEMORE, K.D.; KELTON, D.F.; LESLIE, K.E.; WALTON, J.S.; LUMSDEN, J.H. Relationships between milk urea concentrations and nutritional management, production, and economic variables in Ontario dairy herds. Journal of Dairy Science, v.84, n. p. p.1128-1139, 2001b.

GODDEN, S.M.; LISSEMORE, K.D.; KELTON, D.F.; LUMSDEN, J.H.; LESLIE, K.E.; WALTON, J.S. Analytic validation of an infrared milk urea assay and effects of sample acquisition factors on milk urea results. Journal of Dairy Science, v.83, n.3, p.435-442, 2000.

GONZALO, C.; BARO, J.A.; CARRIEDO, J.A.; SAN PRIMITIVO, S. Use of the Fossomatic method to determine somatic cell counts in sheep milk. Journal of Dairy Science, v.76, p.115, 1993.

GUSTAFSSON, A.H.; CARLSSON, J. Effects of silage quality, protein evaluation systems and milk urea content on milk yield and reproduction in dairy cows. Livestock Production Science, v.37, p.91-105, 1993.

GUSTAFSSON, A.H.; PALMQUIST, D.L. Diurnal variation of rumen ammonia, serum urea, and milk urea in dairy cows at high and low yields. Journal of Dairy Science, v.76, n.2, p.475-484, 1993.

GUSTAFSSON, A.H.; EMANUELSON, M.; OLTNER, R.; WIKTORSSON, H. Milk urea level, its variations and how it is affected by herd, milk yield, stage of lactation season, and feeding: a field study. Uppsala: Swedish University of Agricultural Sciences, Department of Animal Nutrition and Management, 1987. 31p. (Report, 165). 
GUYTON, A.C. Human physiology and mechanisms of disease. 3.ed. Philadelphia: W.B. Saunders, 1982. p.247-292: Formation of urine by the kidney: glomerular filtration, tubular function and plasma clearance.

HARESIGN, W.; COLE, D.J.A. Recent developments in ruminant nutrition, London: Butterworths, 1988. 407p.

HARMEYER, J.; MARTENS, H. Aspects of urea metabolism in ruminants with reference to the goat. Journal of Dairy Science, v.63, p.1707-1728, 1980.

HERRERA-SALDANA, R.; HUBER, J.T. Influence of varying protein and starch degradabilities on performance of lactating cows. Journal of Dairy Science, v.72, n.6, p.1477-1483, 1989.

HOF, G.; VERVOORN, M.D.; LENAERS, P.J.; TAMMINGA, S. Milk urea nitrogen as a tool to monitor the protein nutrition of dairy cows. Journal of Dairy Science, v.80, n.12, p.3333-3340, 1997.

HOFFMANN, M.; STEINHÖFEL, O. Possibilities and restrictions in using milk urea concentrations as markers of the energy and protein balance. Monatshefte fur Veterinär-Medizin, v.45, p.223-227, 1990.

HOGAN, J.P. Protein and amino acid nutrition in the high producing cow. Quantitative aspects of nitrogen utilization by ruminants. Journal of Dairy Science, v.58, n.8, p.1164-1177, 1975.

HOWARD, H.J.; AALSETH, E.P.; ADAMS, G.D.; BUSH, L.J.; McNEW, R.W.; DAWSON, L.J. Influence of dietary protein on reproductive performance of dairy cows. Journal of Dairy Science, v.70, n.8, p.1563-1571, 1987.

HUBER, J.T.; KUNG Jr, L. Protein and nonprotein nitrogen utilization in dairy cattle. Journal of Dairy Science, v.64, n.6, p.1170-1195, 1981.

INTERNATIONAL DAIRY FEDERATION. Recommended methods for somatic cell counting in milk. Brussels, 1984. 35p. (Bulletin, 168).

JAQUETTE, R.; RAKES, A.H.; CROOM, W.J. Effects of dietary protein on milk, rumen, and blood parameters in dairy cattle fed low fiber diets. Journal of Dairy Science, v.69, p.1026-1034, 1986.

JONKER, J.S.; KOHN, R.A. MUN testing: useful but ambiguous. Hoard's Dairyman, v.143, n.6, p.252, 1998.

JONKER, J.S.; KOHN, R.A.; ERDMAN, R.A. Using milk urea nitrogen to predict nitrogen excretion and utilization efficiency in lactating dairy cows. Journal of Dairy Science, v.81, n.10, p.2681-2692, 1998.

JONKER, J.S.; KOHN, R.A.; ERDMAN, R.A. Milk urea nitrogen target concentrations for lactating dairy cows fed according to National Research Council recommendations. Journal of Dairy Science, v.82, n.6, p.1261-1273, 1999. 
JONKER, J.S.; KOHN, R.A.; HIGH, J. Use of milk urea nitrogen to improve dairy cow diets. Journal of Dairy Science, v.85, n.4, p.939-946, 2002a.

JONKER, J.S.; KOHN, R.A.; HIGH, J. Dairy herd management practices that impact nitrogen utilization efficiency. Journal of Dairy Science, v.85, n.5, p.1218-1226, $2002 \mathrm{~b}$.

KAIM, M.; FOLMAN, Y.; NEUMARK, H.; KAUFMANN, W. The effect of protein intake and lactation number on post-part body weight loss and reproductive performance of dairy cows. Animal Production, v.37, p.229, 1983.

KAUFFMAN, A.J.; St-PIERRE, N.R. The relationship of milk urea nitrogen to urine nitrogen excretion in Holstein and Jersey Cows. Journal of Dairy Science, v.84, n.10, p.2284-2294, 2001.

KAUFMANN, W. Variation in composition of the raw material with special regard to the urea content. Milchwissenschaft, v.37, p.6-9, 1982.

KELlOGG, D.W.; URQUHART, N.S.; ORTEGA, A.J. Estimating Holstein lactation curves with a gamma curve. Journal of Dairy Science, v.60, n.8, p.1308-1315, 1977.

KEOWN, J.F.; VAN VLECK, L.D. Extending lactation records in progress to 305-day equivalent. Journal of Dairy Science, v.56, n.8, p.1070-1079, 1973.

KLAUSNER, S.D. Mass nutrient balances on dairy farms. In: THE CORNELL NUTRITION CONFERENCE, Rochester, 1993. Proceedings. Ithaca: Cornell University Press, 1993. p.126-129.

KLUSMEYER, T.H.; McCARTHY Jr., R.D.; CLARCK, J.H.; NELSON, D.R. Effects of source and amount of protein on ruminal fermentation and passage of nutrients to the small intestine of lactating cows. Journal of Dairy Science, v.73, p.3526-3537, 1990.

KOHN, R.A. Caution needed when interpreting MUN. Hoard's Dairyman, v.145, n.2, p.58, 2000.

KOHN, R.A.; KALSCHEUR, K.F.; HANIGAN, M. Evaluation of models for balancing the protein requirements of dairy cows. Journal of Dairy Science, v.81, n.12, p.3401-3414, 1998.

KOHN, R.A.; KALSCHEUR, K.F.; RUSSK-COHEN, E. Evaluation of models to estimate urinary nitrogen and expected nitrogen milk urea nitrogen. Journal of Dairy Science, v.85, n.1, p.227-233, 2002.

KOHN, R.A.; DOU, Z.; FERGUSON, J.D.; BOSTON, R.C. A sensitivity analysis of nitrogen losses from dairy farms. Journal of Environmental Management, v.50, p.417-428, 1997.

KROGER, M. Instrumental fat determination. I. Effects of potassium dichromate concentration and sample storage time on Milko-Tester results. Journal of Dairy Science,v.54, n.5, p. 735-737, 1971. 
KROGER, M. Milk sample preservation. Journal of Dairy Science, v.68, n.3, p.783787, 1985.

KUNG Jr., L.; HUBER, J.T. Performance of high producing cows in early lactation fed protein of varying amounts, sources and degradability. Journal of Dairy Science, v.66, n.2, p.227-234, 1983.

LARSON, S.F.; BUTLER, W.R.; CURRIE, W.B. Reduced fertility associated with low progesterone postbreeding and increase milk urea nitrogen in lactating cows. Journal of Dairy Science, v.80, n.7, p.1288-1295, 1997.

LEE, K.L.; DAYTON, K.P.; KROLL, G.; McGILLIARD, M.L. Effects of preservative, storage time, and storage temperature on milk fat percent, protein percent, and somatic cell count determination. Journal of Dairy Science, v.69, suppl.1, p.211, 1986.

LEWIS, D. Blood-urea concentration in relation to protein utilization in the ruminant. Journal of Agricultural Science, v.48, p.438-446, 1957.

MacLEOD, G.K.; GRIEVE, D.G.; McMILLAN, I.; SMITH, G.C. Effect of varying protein and energy densities in complete rations. Journal of Dairy Science, v.67, p.1421-1429, 1984.

MARSH, W.H.; FINGERHUT, B.; MILLER, H. Automated and manual direct methods for the determination of blood urea. Clinical Chemistry, v.11, p.624, 1965.

MARSHALL, R.T. Means differ by $0,015 \%$ in collaborative study of Babcock and ether extraction fat tests. Journal of Dairy Science, v.68, n.7, p.1642-1646, 1985.

MELENDEZ, P.; DONOVAN, A.; HERNANDEEZ, J. Milk urea nitrogen and infertility in Florida Holstein cows. Journal of Dairy Science, v.83, n.3, p.459463,2000

MEYER, P.M.; MACHADO, P.F.; COLDEBELLA, A.; CORASSIN, C.H.; CASSOLI, L.D.; RODRIGUES, P.H.M. Non-nutritional factors that influence milk urea nitrogen concentration. Journal of Dairy Science, v.85, suppl.1, p.304, 2002.

MIETTINEN, P.V.; JUVONEN, R.O. Diumal variation of serum and milk urea concentrations in dairy cows. Acta Agriculturae Scandinavica, v.40, p.289-296, 1990.

MILLER, R.H.; McDANIEL, B.T.; CORLEY, E.L. Variation in ratio factors for ageadjusting part-lactation records. Journal of Dairy Science, v.50, n.11, p.1819$1823,1967$.

MINZNER, R.A.; KROGER, M. Physicochemical and bacteriological aspects of preserved milk samples and their effect on fat percentage as determined with the Milk-Tester. Journal of Milk and Food Technology, v.37, n.2, p.123, 1974.

MITCHELL, P.L. Misuse of regression for empirical validation of models. Agriculture System, v.54, p.313-326, 1997. 
MOLLER, S.; MATTHEW, C.; WILSON, G.F. Pasture protein and soluble carbohydrate levels in spring dairy pasture and associations with cow performance. Proceedings of the New Zealand Society of Animal Production v.54, p.83-86, 1993.

MONARDES, H.G.; MOORE, R.K.; CORRIGAN, B.; RIOUX, Y. Preservation and storage mechanisms for raw milk samples for use in milk-recording schemes. Journal of Food Protection, v.59, n.2, p.151-154, 1996.

NATIONAL RESEARCH COUNCIL. Nutrient requirements of dairy cattle. 6.ed. Washington: National Academy Press, 1989. 157p.

NATIONAL RESEARCH COUNCIL. Nutrient requirements of dairy cattle. 7.ed. Washington: National Academy Press, 2001. 381p.

NELSON, A.J. Practical application of MUN analysis. In: ANNUAL NORTH EAST DAIRY PRODUCTION AND MEDICINE SYMPOSIUM, 4., Syracuse, 1995. Proceedings. Syracuse: Cornell University Press, 1995. p.35-45.

NETER, J.; KUTNER, M.H.; NACHTSHEIM, C.J.; WASSERMAN, W. Applied linear regression models. 3.ed. Chicago: Irwin, 1996. 720p.

NETO, J.S.; COX, M.; SOUZA, F.B. de; ARRUDA, F.A.V. Modelo de Wood aplicado à curva de lactação de caprinos no Estado do Ceará. In: REUNIÃO ANUAL DA SOCIEDADE BRASILEIRA ZOOTECNIA, 35., Botucatu, 1998. Anais. Botucatu: SBZ, 1998. v.3, p.494-496.

NG-KWAI-HANG, K.F.; HAYES, J.F. Effects of potassium dichromate and sample storage time on fat and protein by Milko-Scan and on protein and casein by a modified Pro-Milk Mk II method. Journal of Dairy Science, v.65, n.10, p.1895$1899,1982$.

NG-KWAI-HANG, K.F.; HAYES, J.F.; MOXLEY, J.E.; MONARDES, H.G. Percentages of protein and nonprotein nitrogen with varying fat and somatic cells in bovine milk. Journal of Dairy Science, v.68, n.5, p.1257-1262, 1985.

NG-KWAI-HANG, K.F.; MOXLEY, J.E.; VAN DE VOORT, F.R. Factors affecting differences in milk fat test obtained by Babcock, Rose-Gottlieb, and infrared methods and in protein test from infrared milk analysis. Journal of Dairy Science, v.71, n.2, p.290-298, 1988.

OLDHAM, J.D. Protein-energy interrelationships in dairy cows. Journal of Dairy Science, v.67, p.1090-1114, 1984.

OLTNER, R.; SJAUNJA, L.O. Evaluation of a rapid method for the determination of urea in cow's milk. Acta Veterinaria Scandinavica, v.23, n.1, p.39-45, 1982.

OLTNER, R.; WIKTORSSON, H. Urea concentrations of milk and blood as influenced by feeding varying amounts of protein and energy to dairy cows. Livestock Production Science, v.10, p.457-467, 1983. 
OLTNER, R.; EMANUELSON, M.; WIKTORSSON, H. Urea concentrations in milk in relation to milk yield, live weight, lactation number and amount and composition of feed given to dairy cows. Livestock Production Science, v.12, p.47-57, 1985.

OTT, R.L. An introduction to statistical methods and data analysis. 4.ed. Wadsworth: Duxbury Press, 1993. 730p.

PAYNE, J.A.; PAYNE, S. The metabolic profile test. New York: Oxford University Press, 1987. 179p.

PURSLEY, R. Economic benefits of synchronization strategies. In: NOVOS ENFOQUES NA PRODUÇÃO E REPRODUÇÃO DE BOVINOS, 2., Uberlândia, 1998. Anais. Uberlândia:Conapec Jr., 1998. p. 21-22.

RAJALA-SCHULTZ, P.J.; SAVILLE, W.J.A.; FRAZER, G.S.; WITTUM, T.E. Association between milk urea nitrogen and fertility in Ohio dairy cows. Journal of Dairy Science, v.84, n.2, p.482-489, 2001.

RATKOWSKY, D.A. Handbook of nonlinear regression models. New York: Marcel Dekker, 1990. 241p.

READ Jr., R.B.; REYES, A.L.; BRADSHAW, J.G. Effect of freezing milk samples on abnormal milk test results. Journal of Dairy Science, v.52, n.2, p.261-262, 1969.

REFSDAL, A.O. Urea in bulk milk as compared to the herd mean of urea in blood. Acta Veterinaria Scandinavica, v.24, p.518-520, 1983.

RIBEIRO, M.N.; EL FARO, L.; PIMENTA FILHO, E.C.; ALBUQUERQUE, L.G. Estudo de funções polinomiais no ajuste da curva de lactação de cabras mestiças no Cariri Paraibano. In: REUNIÃO ANUAL DA SOCIEDADE BRASILEIRA DE ZOOTECNIA, 35., Botucatu, 1998. Anais. Botucatu: SBZ, 1998a. v.3, p.562-564.

RIBEIRO, M.N.; EL FARO, L.; PIMENTA FILHO, E.C.; ALBUQUERQUE, L.G. Comparação de funções matemáticas no ajuste da curva de lactação média de cabras mestiças no Cariri Paraibano. In: REUNIÃO ANUAL DA SBZ, XXXV, Botucatu, 1998. Anais. Botucatu: SBZ, 1998b. v.3, p.565-567.

ROOK, A.J.; FRANCE, J.; DHANOA, M.S. On the mathematical description of lactation curves. Journal of Agricultural Science, v.121, n.1, p.97-102, 1993.

ROSELER, D.K.; FERGUSON, J.D.; SNIFFEN, C.J.; HERREMA, J. Dietary protein degradability effects on plasma and milk urea nitrogen and milk nonprotein nitrogen in Holstein cows. Journal of Dairy Science, v.76, n.2, p.525-534, 1993.

SACKETT, D.L.; HAYNES, R.B.; GUYATT, G.H.; TUGWELL, P. Clinical Epidemiology. 2.ed. Toronto: Little, Brown and Company, 1991. p.51-67.

SAS INSTITUTE. SAS user's guide: statistics. 5.ed. Cary, 1985. 285p.

SAS INSTITUTE. SAS/STAT user's guide 8.0. (compact disc). Cary, 1999. 
SCHEPERS, A.J.; MEIJER, R.G. Evaluation of the utilization of dietary nitrogen by dairy cows based on urea concentration in milk. Journal of Dairy Science, v.81, n.2, p.579-584, 1998.

SHANKS, R.D.; BERGER, P.J.; FREEMAN, A.E.; DICKNSON, F.N. Genetic aspects of lactation curves. Journal of Dairy Science, v.64, n.9, p.1852-1860, 1981.

SOUZA, G.S. Introdução aos modelos de regressão linear e não-linear. Brasília: Embrapa, SPI, SEA, 1998. 489p.

STAPLES, C.R.; THATCHER, W.W.; CLARK, J.H. Relationship between ovarian activity and energy status during the early postpartum period of high producing dairy cows. Journal of Dairy Science, v.73, n.4, p.938-947, 1990.

St-PIERRE, N.R.; THRAEN, C.S. Animal grouping strategies, sources of variation, and economic factors affecting nutrient balance on dairy farms. Journal of Dairy Science, v.82, p.72-83, suppl. 2, 1999.

SWENSON, M.J.; REECE, W.O. Duke's physiology of domestic animals. 11.ed. Ithaca: Cornell University Press, 1993. p. 573-604: Water balance and excretion.

TAMMINGA, S. Nutrition management of dairy cows as a contribution to pollution control. Journal of Dairy Science, v.75, p.345-357, 1992.

THOMANN, R.V.; COLLIER, J.R.; BUTT, A.; CASMAN, E.; LINKER, L.C. Response of the chesapeake bay water quality model to loading scenarios. Washington: Environmental Protection Agency, 1994. 74p.

TIMMS, L.L.; CONNELLY, J.; DOKKEBAKKEN, B. Effects of different container, thaw methods, and preservatives on DHI fat, protein and somatic cell measurement. Journal of Dairy Science, v.70, suppl.1, p.135, 1987.

TREVASKIS, L.M.; FULKERSON, W.J. The relationship between various animal and management factors and milk urea, and its association with reproductive performance of dairy cows grazing pasture. Livestock Production Science, v.57, p.255-265, 1999.

VAN DE VOORT, F.R.; KERMASHA, S.; SMITH, J.P.; MILLS, B.L.; NG-KWAIHANG, K.F. A study of the stability of record of performance milk samples for infrared milk analysis. Journal of Dairy Science, v.70, n.8, p.1515-1523, 1987.

VAN HORN, H.H.; WILKIE, A.C.; POWERS, W.J.; NORDSTEDT, R.A. Components of dairy manure management systems. Journal of Dairy Science, v.77, p.20082030, 1994.

VAN SOEST, P.J. Nutritional ecology of the ruminant. Ithaca: Cornell University Press, 1994. 476p.

VAN VLECK, L.D.; HENDERSON, C.R. Estimates of genetic parameters of some functions of part lactation milk records. Journal of Dairy Science, v.44, n.6, p.1073-1084, 1961a. 
VAN VLECK, L.D.; HENDERSON, C.R. Ratio factors for adjusting monthly test-day data for age and season of calving and ratio factors for extending part lactation records. Journal of Dairy Science, v.44, n.6, p.1092-1102, 1961 b.

WOLFSCHOON-POMBO, A.F. Tests on the use of the Milko-Tester MK-III for the determination of milk fat. Revista do Instituto de Laticínios Cândido Tostes, v.33, n.196, p. 11, 1978.

WOLFSCHOON-POMBO, A.F. Investigations on the amount and composition of NPN in milk. Munich, 1981. 121p. Thesis (PhD) - University of Munich.

WOOD, P.D.P. Algebraic model of the lactation curve in cattle. Nature, v.216, p.164 $165,1967$. 